\title{
Insulin monotherapy versus combinations of insulin with oral hypoglycaemic agents in patients with type 2 diabetes mellitus (Review)
}

\author{
Goudswaard AN, Furlong NJ, Valk GD, Stolk RP, Rutten GEHM
}
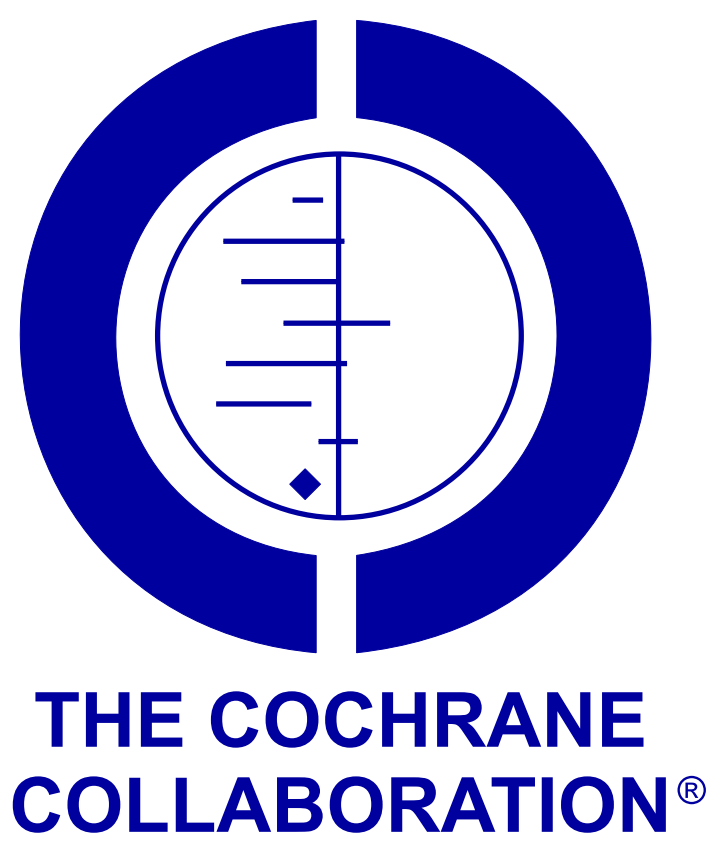

This is a reprint of a Cochrane review, prepared and maintained by The Cochrane Collaboration and published in The Cochrane Library 2006, Issue 2

http://www.thecochranelibrary.com

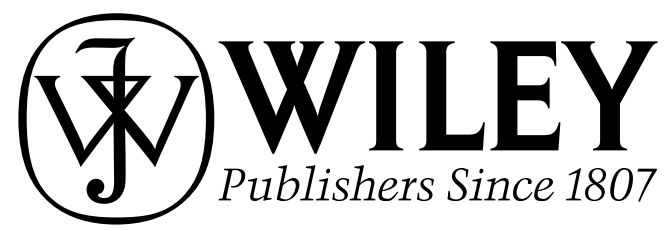

Insulin monotherapy versus combinations of insulin with oral hypoglycaemic agents in patients with type 2 diabetes mellitus (Review) Copyright $\odot 2006$ The Cochrane Collaboration. Published by John Wiley \& Sons, Ltd 


\section{TABLE OF CONTENTS}

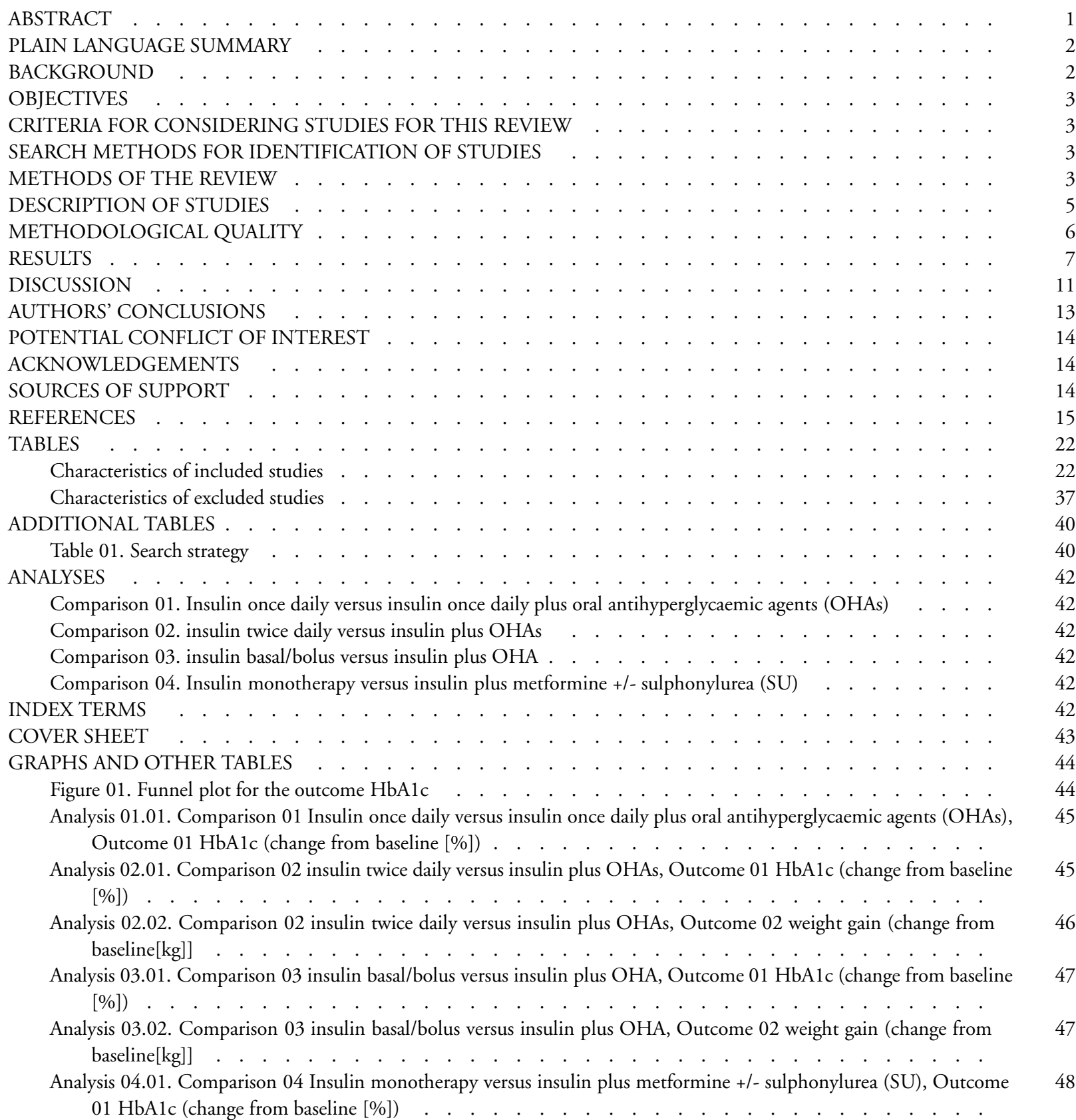




\title{
Insulin monotherapy versus combinations of insulin with oral hypoglycaemic agents in patients with type 2 diabetes mellitus (Review)
}

\author{
Goudswaard AN, Furlong NJ, Valk GD, Stolk RP, Rutten GEHM
}

\begin{abstract}
This record should be cited as:
Goudswaard AN, Furlong NJ, Valk GD, Stolk RP, Rutten GEHM. Insulin monotherapy versus combinations of insulin with oral hypoglycaemic agents in patients with type 2 diabetes mellitus. The Cochrane Database of Systematic Reviews 2004, Issue 4. Art. No.: CD003418.pub2. DOI: 10.1002/14651858.CD003418.pub2.
\end{abstract}

This version first published online: 18 October 2004 in Issue 4, 2004.

Date of most recent substantive amendment: 25 August 2004

\begin{abstract}
A B S T R A C T
Background

It is unclear whether patients with type 2 diabetes who have poor glycaemic control despite maximal oral hypoglycaemic agents (OHAs) should be commenced on insulin as monotherapy, or insulin combined with oral hypoglycaemic agents (insulin-OHA combination therapy).
\end{abstract}

\section{Objectives}

To assess the effects of insulin monotherapy versus insulin-OHA combinations therapy.

\section{Search strategy}

Eligible studies were identified by searching MEDLINE, EMBASE, and The Cochrane Library. Date of last search: May 2004.

\section{Selection criteria}

Randomised controlled trials (RCTs) with 2 months minimum follow-up duration comparing insulin monotherapy (all schemes) with insulin-OHA combination therapy.

Data collection and analysis

Data extraction and assessment of study quality were undertaken by three reviewers in pairs.

\section{Main results}

Twenty RCTs (mean trial duration 10 months) including 1,811 participants, with mean age 59.8 years and mean known duration of diabetes 9.6 years. Overall, study methodological quality was low. Twenty-eight comparisons in 20 RCTs were ordered according to clinical considerations. No studies assessed diabetes-related morbidity, mortality or total mortality. From 13 studies (21 comparisons), sufficient data were extracted to calculate pooled effects on glycaemic control. Insulin-OHA combination therapy had statistically significant benefits on glycaemic control over insulin monotherapy only when the latter was applied as a once-daily injection of NPH insulin. Conversely, twice-daily insulin monotherapy (NPH or mixed insulin) provided superior glycaemic control to insulin-OHA combination therapy regimens where insulin was administered as a single morning injection. In more conventional comparisons, regimens utilising OHAs with bedtime NPH insulin provided comparable glycaemic control to insulin monotherapy (administered as twice daily, or multiple daily injections). Overall, insulin-OHA combination therapy was associated with a $43 \%$ relative reduction in total daily insulin requirement compared to insulin monotherapy. Of the 14 studies (22 comparisons) reporting hypoglycaemia, 13 demonstrated no significant difference in the frequency of symptomatic or biochemical hypoglycaemia between insulin and combination therapy regimens. No significant differences in quality of life related issues were detected. Combination therapy with bedtime $\mathrm{NPH}$ insulin resulted in statistically significantly less weight gain compared to insulin monotherapy, provided metformin was used \pm sulphonylurea. In all other comparisons no significant differences with respect to weight gain were detected.

Insulin monotherapy versus combinations of insulin with oral hypoglycaemic agents in patients with type 2 diabetes mellitus (Review)

Copyright $(2006$ The Cochrane Collaboration. Published by John Wiley \& Sons, Ltd 


\section{Authors' conclusions}

Bedtime NPH insulin combined with oral hypoglycaemic agents provides comparable glycaemic control to insulin monotherapy and is associated with less weight gain if metformin is used.

\section{PLAIN LANGUAGESUMMARY}

Simple application of a single daily insulin injection in addition to oral hypoglycaemic agents may facilitate the initiation of insulin therapy in type 2 diabetes mellitus

This review examined 20 trials including 1,811 participants which compared insulin monotherapy with insulin in combination with oral hypoglycaemic agents (OHA) in insulin-requiring patients with type 2 diabetes. The results suggest that a bedtime NPH insulinoral hypoglycaemic agent combination therapy regimen provides comparable glycaemic control to insulin monotherapy. Due to lack of studies it remains unclear whether insulin-OHA combination regimens with metformin alone are superior to those with metformin plus a sulphonylurea. In most cases no significant differences in hypoglycaemic events were observed between insulin mono- and OHA combination therapy. No study assessed diabetes-related morbidity or mortality.

\section{B A C K G R O U N D}

Diabetes mellitus is a chronic metabolic disorder resulting from a fundamental defect in insulin secretion, insulin action, or both. Consequential chronic hyperglycaemia (i.e. elevated levels of plasma glucose) with associated disturbances of carbohydrate, fat and protein metabolism ensues. Long-term (microvascular) complications of diabetes mellitus include retinopathy, nephropathy and neuropathy. The risk of cardiovascular disease is also increased. For a detailed overview of diabetes mellitus, please see under 'Additional information' in the information on the Metabolic and Endocrine Disorders Group on The Cochrane Library (see 'About the Cochrane Collaboration', 'Collaborative Review Groups-CRGs'). For an explanation of methodological terms, see the main Glossary on The Cochrane Library.

In the United Kingdom Prospective Diabetes Study (UKPDS) of newly diagnosed type 2 diabetes patients, compared with conventional therapy, intensive glucose control (mean $\mathrm{HbA1c} 7.0 \%$ versus $7.9 \%$ ) resulted in a statistically significant $25 \%$ relative risk reduction of microvascular complications, and in a non-significant $16 \%$ risk reduction of myocardial infarction (UKPDS 33). Consequently, most glycaemic management guidelines for type 2 diabetes recommend a target $\mathrm{HbA} 1 \mathrm{c}$ less than $7 \%$. Insulin therapy is recommended for patients who are unable to reach this target with oral hypoglycaemic agents alone.

Initial treatment of patients with type 2 diabetes mellitus should be in the form of diet and education. Weight reduction in obese patients and exercise to improve insulin sensitivity and glucose tolerance (Agurs 1997; Bosello 1997). If non-pharmacological measures are insufficient, additional therapy with oral hypoglycaemic agents is indicated. Later, as oral agents become less efficacious, exogenous insulin, given either as a monotherapy or in combination with (an) oral hypoglycaemic agent(s), may be required.
The UKPDS also demonstrated that despite treatment with a combination of oral agents, a substantial number of patients require insulin therapy to maintain strict glycaemic control (Turner 1999). The UKPDS did not investigate the use of insulin-oral hypoglycaemic agents (OHA) combination therapy although when patients require insulin, benefit may be obtained from combining insulin with oral hypoglycaemic agents.

Historically, the effects of insulin have been controversial (Zavaroni 1989; Stout 1990). The side effects of weight gain and hypoglycaemia are well known, though it was also long thought that exogenous insulin was a causative risk factor for cardiovascular complications. The UKPDS and other studies have found no evidence for this (Ruige 1998). It is also uncertain if, and how, insulin therapy may influence 'quality of life' and patient treatment satisfaction. Improving glycaemia per se may improve general well-being, however, daily injections with insulin, home monitoring of blood glucose, episodes of hypoglycaemia and referral from primary to secondary care can interfere with the daily functioning of patients (de Sonnaville 1998, Goddijn 1999, van der Does 1996).

Three previous reviews comparing insulin monotherapy to insulin / oral hypoglycaemic agent combination therapy have focussed on insulin combined with sulphonylureas or placebo, excluding other groups of oral agents (Peters 1991; Pugh 1992; Johnson 1996). These reviews included studies where either insulin-treated patients were randomised to the addition of a sulphonylurea or placebo, or where insulin-requiring patients with poor glycaemic control despite oral hypoglycaemic agents were randomised to receive insulin combined with sulphonylurea therapy, or insulin alone. These reviews were of limited design and did not explicitly address the aim of the present study, namely to determine the optimum initial insulin treatment strategy for insulin-requiring type 2 patients. Despite the apparent similarities of these reviews, the authors' conclusions differed. Peters 1991 concluded that com- 
bination therapy should not be used in insulin-treated patients with type 2 diabetes since improvement was only slight and blood glucose values were not normalised with this therapy. The later reviews of Pugh 1992 and Johnson 1996 however, recommended insulin / sulphonylurea combination therapy, finding it to be more efficacious than insulin alone.

Yki-Järvinen 2001 published a fairly comprehensive overview of studies on insulin-OHA combination therapies, though this review did not meet the criteria of the Cochrane Collaboration. Therefore, an up-to-date systematic review conforming to the methods of the Cochrane Collaboration was undertaken to clarify the potential benefits of combination therapy compared to insulin monotherapy.

\section{O B J E C T I VES}

To assess the effects of insulin monotherapy versus insulin-oral hypoglycaemic agents combination therapy.

\section{CRITERIA FOR CONSIDERING STUDIES FOR THIS REVIEW}

\section{Types of studies}

Randomised controlled trials (RCTs of any design) with a minimum follow-up duration of two months.

\section{Types of participants}

Patients with type 2 diabetes mellitus (according to appropriate diagnostic criteria of the time) and inadequate glycaemic control despite oral hypoglycaemic agents. To be consistent with changes in classification and diagnostic criteria of the disease, the diagnosis should have been established using the standard criteria valid at the outset of the trial (NDDG 1979; WHO 1980; WHO 1985; ADA 1997; ADA 1999; WHO 1999). Since changes in diagnostic criteria may produce significant variability in the clinical characteristics of the patients included as well as in the results obtained, these differences were considered and later explored in a sensitivity analysis.

\section{Types of intervention}

The following possible types of interventions and comparisons were included:

Insulin monotherapy compared to combinations of insulin with single or multiple oral hypoglycaemic agents.

\section{Types of outcome measures}

\section{MAIN OUTCOME MEASURES}

1. Any diabetes-related morbidity: myocardial infarction, angina, heart failure, stroke, renal failure, amputation (of at least one digit), vitreous haemorrhage, retinal photocoagulation, blindness in one eye, or cataract extraction;
2. Glycaemic control (fasting blood glucose, HbA1, HbA1c).

\section{ADDITIONAL OUTCOME MEASURES}

3. Quality of life (ideally using validated scales);

4. Patient satisfaction (ideally using validated scales);

5. Amount of insulin necessary for good glycaemic control;

6. Adverse effects: incidence of hypoglycaemia, weight gain, gastrointestinal symptoms.

\section{TIMING OF OUTCOME ASSESSMENT}

- Short-term: 2 - 6 months;

- Intermediate-term: greater than 6 to 12 months;

- Long-term: more than 12 months.

\section{SEARCH METHODSFOR IDENTIFICATION OFSTUDIES}

See: Metabolic and Endocrine Disorders Group methods used in reviews.

One reviewer (ANG) searched the following computerised bibliographic databases: The Cochrane Library, MEDLINE and EMBASE, with no language restriction. See under 'Additional tables' for a detailed MEDLINE-search strategy (Table 01). Relevant published studies of any language were included. The reference lists of relevant trials and reviews identified were also scrutinised to identify other potentially relevant studies.

\section{ELECTRONIC SEARCHES}

Electronic search strategies were used to identify relevant trials (as specified under 'types of studies') and reviews/meta-analyses (for identification of additional trials). The following databases were searched:

- The Cochrane Library (issue 2, 2004; including the Cochrane Controlled Trials Register (CCTR) and the Database of Reviews of Effectiveness (DARE);

- MEDLINE (1966 to 05/2004);

- EMBASE (1974 to 05/2004).

We will also search databases of ongoing trials:

- Current Controlled Trials (www.controlled-trials.com);

- The National Research Register (www.update-software.com/ National/nrr-frame.html).

\section{METHODSOF THE REVIEW}

\section{TRIALS SELECTION}

References identified from searches were entered into Reference Manager 10. To determine the studies to be assessed further, two independent reviewers (ANG, GDV) scanned titles, abstract and

Insulin monotherapy versus combinations of insulin with oral hypoglycaemic agents in patients with type 2 diabetes mellitus (Review) 3

Copyright $(2006$ The Cochrane Collaboration. Published by John Wiley \& Sons, Ltd 
keywords of every record retrieved. Full articles were retrieved for further assessment if the information given suggested that the study:

1. Included patients with type 2 diabetes mellitus;

2. Compared insulin with a combination of insulin with (an) oral hypoglycaemic agent(s);

3. Assessed one or more relevant clinical outcome measure;

4. Used random allocation to comparison groups.

Where details regarding these criteria were inadequate from the information given in the title and abstract, the full article was retrieved for clarification. Interrater agreement for study selection was measured using the kappa statistic (Cohen 1960). Differences in opinion were discussed with a third party (RPS). Where resolution of disagreement was not possible, the article was added to those 'awaiting assessment' and the authors contacted for clarification. When no clarification was provided, the review group editorial base would have been consulted. If the results of a trial were reported in separate articles data were appropriately combined and analysed as one study.

\section{QUALITY ASSESSMENT OF TRIALS}

Each trial was independently assessed by two reviewers (ANG, GDV). Interrater agreement was calculated using the kappa statistic. In cases of disagreement, the Cochrane Metabolic and Endocrine Disorders Group would have been consulted and a judgement made based on consensus.

The trials were assessed on quality using a selection of the 17-item Maastricht- Amsterdam Criteria List (Van Tulder 1997), which includes criteria of Jadad (Jadad 1996) and Schulz (Schulz 1995). The following factors were scored (total score range from 0 - 7):

1. Minimisation of selection bias - a) was the randomisation procedure adequate? $\mathrm{b}$ ) was the allocation concealment adequate? 2. Minimisation of performance bias - were a) the patients and b) people administering the treatment blind to the intervention?

3. Minimisation of attrition bias - a) were withdrawals and dropouts completely described? b) was analysis by intention-totreat?

4. Minimisation of detection bias - were a) outcome assessors blind to the intervention?

Based on these criteria, studies were subdivided into three categories:

A - all quality criteria met: low risk of bias.

$\mathrm{B}$ - one or more of the quality criteria only partly met: moderate risk of bias.

$\mathrm{C}$ - one or more criteria not met: high risk of bias.

This classification was used as the basis for a sensitivity analysis. The influence of individual quality criteria were also used in sensitivity analyses. Studies were not excluded on the basis of methodological criteria alone.

\section{DATA EXTRACTION}

Three reviewers (ANG, GDV, NF) independently extracted the data including:

1. General information: published/unpublished, title, authors, reference/source, contact address, country, urban/rural etc., language of publication, year of publication, duplicate publications, sponsoring, setting.

2. Trial characteristics: design, duration, randomisation (and method), allocation concealment (and method), blinding (patients, people administering treatment, outcome assessors), assessment of blinding.

3. Intervention(s): placebo included, interventions(s) (dose, route, timing), comparison intervention(s) (dose, route, timing).

4. Patients: sampling (random/convenience), exclusion criteria, total number and number in comparison groups, sex, age, duration of diabetes, similarity of groups at baseline (including any comorbidity), assessment of compliance, withdrawals / losses to follow-up (reasons/description), subgroups.

5. Outcomes: outcomes specified above (also: what was the main outcome assessed in the study?), any other outcomes assessed, other events, length of follow-up, quality of reporting of outcomes.

6. Results: for outcomes and times of assessment (including a measure of variation), if necessary converted to measures of effect specified below; intention-to-treat analysis.

A template data extraction form was developed, piloted and approved by the Metabolic and Endocrine Disorders Group Editorial Base before final data extraction commenced. Data extraction and data entry were performed independently in pairs (ANG / GDV and ANG / NF). Differences in data extraction were resolved by consensus with the fourth reviewer (RPS), with referral to the original article. Where the published report contained incomplete (or absent) data (see data extraction list), the reviewers contacted the first author using the standard letter from the Editorial Base.

\section{DATA ANALYSIS}

Available data were included in a meta-analysis if they were sufficiently similar and of sufficient quality. For dichotomous data the results are expressed as odds ratios (OR) with corresponding 95\% confidence intervals (95\% CIs), and continuous data as weighted mean difference with $95 \%$ CIs, or as standardised weighted mean difference where outcomes were conceptually the same but measured in different ways (Rosenthal 1994; Mulrow 1997; Lau 1997). Where studies that did not provide HbA1c change-from-baseline values, these data were computed from baseline and post-treatment values, eventually distracted from graphs. When standard deviations of mean differences for the main outcome HbA1c were not provided in the publications, these data were computed assuming a general correlation coefficient that was derived from baseline and post-treatment outcomes for HbA1c in studies that presented accompanying SDs (see below). Glycated haemoglobin values determined with different methodologies were standardized to a reference range of 4.0 to $6.0 \%$ (Little 1986; DCCT 1993). Insulin requirement in combination therapy 
regimens was expressed as a relative reduction in insulin dose compared to monotherapy, expressed as percentage (unweighted mean; 95\% CI). Differences underlying the results of studies (statistical heterogeneity) were assessed using both the Q-test (with a P-value less than 0.1 considered as significant) and by Isquared (Higgins 2003). Clinical heterogeneity was surveyed by comparing the studies with regard to different clinical parameters: patient characteristics (e.g. previous treatment), disease duration, interventions and outcome. Where significant clinical or statistical heterogeneity was found, it was considered unreasonable to assume one 'true' effect underlying the data constant across different populations, necessitating a random-effects model to pool data. (DerSimonian 1986).

For each study the mean changes from baseline and standard deviations of the outcome HbA1[c] were extracted, if available. If not available, mean change scores of $\mathrm{HbA1}$ [c] were calculated by subtracting baseline from post-treatment values. Matching standard deviations were computed in SPSS 11.0 with a formula (formula 1), which included a general correlation coefficient between baseline and post-treatment values of $\mathrm{HbA} 1[\mathrm{c}]$ of 0.5 . This figure was set 0.1 point lower than the correlation coefficient that was calculated from studies that provided information on change scores inclusive standard deviations, and which appeared to be 0.6 in most studies (formula 2) (Armitage 2002).

Formula 1: SPSS syntax for computing standard deviations of changes from baseline values of $\mathrm{HbA1}[\mathrm{c}]$

$\mathrm{SD}=\operatorname{sqrt}\left(\mathrm{sd} \_\mathrm{tr} \_\mathrm{b}^{* *} 2+\mathrm{sd} \_\mathrm{tr} \_\mathrm{p}^{* *} 2-2^{*}\right.$ corr ${ }^{*}$ sd_tr_b ${ }^{*}$ sd_tr_ p).

abbreviations:

sd $=$ standard deviation

Sqrt $=$ square root

sd_tr_b = standard deviation of mean baseline HbA1[c]

sd_tr_p = standard deviation of mean post treatment $\operatorname{HbA1}[\mathrm{c}]$

corr $=$ correlation coefficient between baseline and post-treatment values of $\mathrm{HbA1}[\mathrm{c}]$

Formula 2: SPSS syntax for computing correlation coefficient between baseline and post-treatment values of $H b A 1[c]$

corr_tr $=\left(\right.$ sd_tr_b $b^{* *} 2+$ sd_tr_p ${ }^{* *} 2$ - sddiff_tr** 2$) /\left(2^{*}\right.$ sd_tr_ b*sd_tr_p).

abbreviations:

corr_tr $=$ correlation coefficient between baseline and posttreatment values of $\mathrm{HbA} 1$ [c]

sd_tr_b = standard deviation of mean baseline HbA1[c]

sd_tr_p = standard deviation of mean post treatment $\operatorname{HbA1}[\mathrm{c}]$

sddiff_tr $=$ standard deviation of change from baseline HbA1 [c]

\section{SUBGROUP ANALYSES}

Subgroup analyses were planned for the following variables: different oral hypoglycaemic agent(s) and different types of insulin, timing and frequency of insulin injections.

\section{SENSITIVITY ANALYSES}

Sensitivity analyses were planned to explore the influence of the following factors on effect size:

1. Repeating the analysis excluding unpublished studies.

2. Repeating the analysis taking account of study quality, as specified above.

3. Repeating the analysis excluding any very long or large studies to establish how much they dominate the results.

\section{ASSESSMENT OF SMALL STUDY BLAS}

Small study bias was evaluated by using a funnel plot method (Egger 1997).

\section{DESCRIPTIONOFSTUDIES}

\section{STUDIES IDENTIFIED}

The search strategy provided 1,709 citations. After exclusion of doubles and studies not related to the objective of the review, two reviewers independently assessed the remaining 192 abstracts. Full text was obtained of 127 potentially relevant studies, of which 22 fulfilled the inclusion criteria of the review. Three studies found after the last search are waiting for assessment and will be included in the first update of this review (Olsson 2002; Stehouwer 2003; Goudswaard 2004).

\section{INTERRATER AGREEMENT}

The observed agreement in trial selection was $94 \%$ (kappa $=0.71$; $95 \%$ CI 0.56 to 0.86 ). For unclear cases agreement was reached by reading the article together, followed by discussion. The observed overall agreement in the extraction of the data was $95 \%$. After discussion all disagreements were resolved.

\section{MISSING DATA}

We contacted Chow, Fövényi, Holman, and Pontiroli for further details regarding their studies; all provided further information (Chow 1995; Fövényi 1997; Holman 1987; Pontiroli 1990).

\section{EXCLUDED STUDIES}

Reasons for exclusion of studies are given in 'Table of excluded studies'. Main reasons for exclusion were: Patients were previously treated with insulin $(n=47)$, absence of a treatment arm with either monotherapy with insulin or with a combination of insulin with oral hypoglycaemic agents $(n=32)$, a non-appropriate study design $(\mathrm{n}=12)$, and "other reasons" $(\mathrm{n}=14)$.

\section{INCLUDED STUDIES}

Twenty RCTs described in 22 articles met the inclusion criteria. The results of two RCTs were reported in four separate articles. Data from these duplicate publications were appropriately combined (Gutniak 1987; Karlander 1991, Yki-Järvinen 1999; Mäkimattila 1999) and thus analysed as two studies (Gutniak 1987; Yki-Järvinen 1999). Fifteen articles (75\%) were published in English, three in German (Bachmann 1988; Lotz 1988; Lundershausen 1987), one in Dutch (Wolffenbuttel 1991), one in Hungarian (Fövényi 1997), and two in Chinese (Sun 1995, Xu 
2001). No eligible trials were found before the year 1987. At least $50 \%$ of the studies were sponsored by the pharmaceutical industry.

\section{STUDIES AND PARTICIPANTS}

All 20 included studies were randomised controlled studies, of which 16 had a parallel design, and four a crossover design (Holman 1987; Riddle 1998; Pontiroli 1990; Ravnik-Oblak 1995). Weighted mean trial duration was 10.0 months (range 2 to 36 months). A total of 1811 participants (mean per study 91; range 10 to 432 ) were included in these studies, with $46 \%$ men (range $29 \%$ to $64 \%$ ). Gender was not reported in five trials (Gutniak 1987; Lotz 1988; Ravnik-Oblak 1995; Riddle 1992; Shank 1995). Participants had mean age of 59.8 years (95\% CI 57.6 to 62.1 ), and mean known duration of diabetes was 9.6 years (95\% CI 8.3 to 10.9$)$. All studies provided information on oral hypoglycaemic therapy at baseline. Further details and criteria for entry into the individual studies are listed in the Table "Characteristics of included studies".

\section{STUDY SETTINGS}

In one study patients were recruited in primary care (Holman 1987), all other studies were conducted in secondary care. In three studies patients were admitted to hospital for baseline measurements and initiation of insulin therapy (Gutniak 1987; RavnikOblak 1995; Yki-Järvinen 1992).

CHARACTERISTICS OF INTERVENTIONS (see table 'Characteristics of included studies')

Twenty studies providing 28 comparisons between insulin monotherapy and insulin-oral hypoglycaemic agent combination regimens were evaluated. In both monotherapy and combination therapy groups, insulin was applied as a once-daily (morning or bedtime), twice-daily, or a multiple-daily injection regimen. Oral hyperglycaemic agents utilised included sulphonylureas (75\%), metformin $(4 \%)$ or both $(21 \%)$. Comparisons were initially categorised according to mode of insulin monotherapy, and subsequently sub-categorised according to combination therapy regimen used, to provide clinically relevant comparisons:

1) Insulin monotherapy (once-daily injection) versus combination regimens (Holman 1987; Lundershausen 1987; Pontiroli 1990; Riddle 1989; Riddle 1992; Riddle 1998; Shank 1995; Sun 1995; Xu 2001).

2) Insulin monotherapy (twice-daily injection) versus combination regimens (Bachmann 1988; Chow 1995; Fövényi 1997; Gutniak 1987; Lotz 1988; Ravnik-Oblak 1995; Wolffenbuttel 1991; Wolffenbuttel 1996; Yki-Järvinen 1992; Yki-Järvinen 1999).

3) Insulin monotherapy (multiple-daily injections) versus combination regimens (Bastyr 1999; Holman 1987; Yki-Järvinen 1992).

\section{OUTCOME MEASURES OF INCLUDED STUDIES}

No studies assessed diabetic complications, diabetes-related mortality or total mortality.

All except three studies (Lundershausen 1987, Bachmann 1988; Ravnik-Oblak 1995) reported glycaemic control as mean values of $\mathrm{HbA}_{1}$ (Holman 1987; Lotz 1988; Riddle 1989; Riddle 1992) or $\mathrm{HbA}_{1 c}$. Five studies provided change-from-baseline values for glycated haemoglobin with standard deviations (Bastyr 1999; Riddle 1992; Riddle 1998; Yki-Järvinen 1992; Yki-Järvinen 1999). Fasting blood glucose values were not reported in two studies (Fövényi 1997; Yki-Järvinen 1992). Three studies did not provide the method of analysis for glycated haemoglobin (Sun 1995; Bastyr 1999; Xu 2001).

Seven studies (13 comparisons) provided change-from-baseline values for body weight with standard deviations (Bastyr 1999; Chow 1995; Fövényi 1997; Gutniak 1987; Riddle 1992; YkiJärvinen 1992; Yki-Järvinen 1999).

Insulin requirement was reported in all but three studies (RavnikOblak 1995; Sun 1995; Xu 2001).

Patient satisfaction, general well-being or quality of life was assessed in three studies (Chow 1995; Riddle 1989; Yki-Järvinen 1992).

All but seven studies (Fövényi 1997; Lundershausen 1987; Pontiroli 1990; Ravnik-Oblak 1995; Riddle 1989; Wolffenbuttel 1991; Xu 2001) in some way provided information on hypoglycaemic events, although only three (Riddle 1992; Yki-Järvinen 1992; Yki-Järvinen 1999) provided number of hypoglycaemic events with standard deviations.

Other adverse effects were reported in two studies (Bastyr 2000; Riddle 1998).

\section{METHODOLOGICALQUALITY}

The methodological quality scores of the included studies (scale range $0(\min )$ to $7(\max ))$ were assigned using the criteria described above, and are listed in the table of included studies. Only information published in the trials was used to determine a quality score. Inter-observer calculation of the items of study quality revealed a substantial observed agreement of $82 \%$ (kappa $=0.62 ; 95 \% \mathrm{CI}$ 0.48 to 0.76 ). Mean study quality was 2.6 (95\% CI 1.5 to 3.7 ). Mean patients' drop-out rate was $5.5 \%$. Disregarding one study with a drop-out rate of 51\% (Bachmann 1988), mean drop-out rate was only $1.4 \%$. None of the studies reported a power calculation. Of the four cross-over studies none had a wash-out period, and two analysed data for carryover and period effects. Inclusion criteria were not described in four studies (Holman 1987; Lundershausen 1987; Riddle 1992; Xu 2001). In most studies patients with co-morbidity and diabetes complications were excluded.

\section{RANDOMISATION}

Eight studies detailed the method of randomisation (Bastyr 2000; Chow 1995; Lotz 1988; Riddle 1989; Riddle 1992; Shank 1995; Yki-Järvinen 1992; Yki-Järvinen 1999), although in two trials the method could not be considered as adequate (Chow 1995; Lotz 1988). Fifteen studies (75\%) had inadequate or unclear allocation concealment, and in five studies allocation concealment was 
adequate (Riddle 1989; Riddle 1992; Riddle 1998; Yki-Järvinen 1992; Yki-Järvinen 1999).

\section{BLINDING}

Stated method of blinding was open in eleven studies, single-blinding in two, double-blinding in three, and triple-blinding in four. None of the studies reported checked blinding conditions in patients and health care providers.

\section{DROP-OUTS AND INTENTION-TO-TREAT ANALYSIS}

Seventy per cent of studies reported drop-outs in some detail. Intention-to-treat analyses were described in six studies.

\section{R E S U L T S}

\section{EFFECTS OF INSULIN MONOTHERAPY VERSUS IN- SULIN IN COMBINATION WITH HYPOGLYCAEMIC AGENTS}

\section{GLYCAEMIC CONTROL (glycated haemoglobin)}

Comparisons were initially categorised according to mode of insulin monotherapy (once-daily, twice-daily, or multiple-daily injections), and subsequently sub-categorised according to combination therapy regimen used, to provide clinically useful subgroups as pre-planned. From thirteen studies (21 comparisons) sufficient data were extracted to calculate pooled effects on glycaemic control.

(a) Once-daily insulin monotherapy regimens (Comparison 01.01) In nine comparisons, insulin monotherapy applied as either a single morning (Pontiroli 1990) or evening injection (Holman 1987; Riddle 1989; Riddle 1992; Riddle 1998; Shank 1995; Sun 1995; Xu 2001) was compared with a matching insulin injection combined with a sulphonylurea (SU). One study (Lundershausen 1987) provided no information on timing of insulin injections. Data from five comparisons comparing a single evening insulin injection to evening insulin combined with daytime sulphonylurea were pooled in a meta-analysis (Riddle 1992; Riddle 1998; Shank 1995; Sun 1995; Xu 2001). Insulin-oral hypoglycaemic agents (OHA) combination therapy was associated with a significant mean (pooled weighted mean difference) lowering of $\mathrm{HbA1c}$ of $0.3 \%$ ( $95 \%$ CI 0.0 to $0.6 ; \mathrm{P}=0.03)$ compared to insulin monotherapy. Heterogeneity was low $\left(\mathrm{I}^{2}=16,3 \%\right.$; $\mathrm{Chi}^{2}=4.8 ; \mathrm{P}$ $=0.31$ ) Four comparisons were not included in the meta-analysis. Lundershausen 1987 reported no outcome data for $\operatorname{HbA1}(\mathrm{c})$, and three cross-over studies with heterogeneous design had potential carryover effect for HbA1(c) (Holman 1987; Pontiroli 1990; Riddle 1989). Pontiroli 1990 and Riddle 1989 reported better glycaemic control with combination therapy, whereas Holman 1987 and Lundershausen 1987 found no difference compared with insulin monotherapy.

(b) Twice-daily insulin monotherapy regimens (Comparison 02.01) (i) Bedtime neutral protamine Hagedorn (NPH) insulin plus oral hypoglycaemic agents

In seven comparisons, twice-daily insulin monotherapy was compared with bedtime NPH combined with either SU (1) (Fövényi 1997; Wolffenbuttel 1996; Yki-Järvinen 1999), metformin (2) (Yki-Järvinen 1999), or SU plus metformin (3) (Chow 1995; YkiJärvinen 1992; Yki-Järvinen 1999).

- Bedtime NPH plus SU (three comparisons) (Comparison 02.01.01)

Insulin-OHA combination therapy was associated with a nonsignificant mean (pooled weighted mean difference) lowering of HbAlc of $0.1 \%$ (95\% CI -0.9 to $1.1 ; \mathrm{P}=0.87)$ compared to insulin monotherapy. Heterogeneity was high $\left(\mathrm{I}^{2}=90.4 \%\right.$; $\mathrm{Chi}^{2}=$ 20.9; $\mathrm{P}<0.0001)$. After elimination of one large study of poor quality (Fövényi 1997) insulin monotherapy was associated with a non-significant mean (pooled weighted mean difference) lowering of HbA1c of $0.4 \%$ ( $95 \%$ CI -0.9 to $0.1 ; \mathrm{P}=0.08$ ) compared to insulin-OHA combination therapy. There was no statistically significant heterogeneity $\left(\mathrm{I}^{2}=0 \%\right.$; $\left.\mathrm{Chi}^{2}=0.81 ; \mathrm{P}=0.37\right)$.

- Bedtime NPH plus metformin (one comparison) (Comparison 02.01.02)

Insulin-OHA combination therapy was associated with a significant mean lowering of HbA1c of $0.6 \%(\mathrm{P}<0.05)$ compared to insulin monotherapy.

- Bedtime NPH plus SU plus metformin (three comparisons) (Comparison 02.01.03)

Insulin monotherapy was associated with a non-significant mean (pooled weighted mean difference) lowering of HbAlc of $0.2 \%$ (95\% CI -0.7 to $0.4 ; \mathrm{P}=0.54$ ) compared to insulin-OHA combination therapy. Heterogeneity was moderate $\left(\mathrm{I}^{2}=33.1 \%\right.$; $\mathrm{Chi}^{2}=$ 2.99; $\mathrm{P}=0.22$ ). Elimination of one study of poor quality (Chow 1995) did not change this result.

(ii) Morning NPH insulin plus oral hypoglycaemic agents In four comparisons, twice-daily insulin monotherapy was compared with morning NPH insulin combined with SU (Lotz 1988; Wolffenbuttel 1991; Wolffenbuttel 1996) or SU plus metformin (Yki-Järvinen 1992) (Comparison 02.01.04). Insulin monotherapy was associated with a significant mean (pooled weighted mean difference) lowering of HbA1c of $0.4 \%$ (95\% CI 0.1 to 0.8 ; $\mathrm{P}=$ $0.03)$ compared to insulin-OHA combination therapy. There was no statistically significant heterogeneity $\left(\mathrm{I}^{2}=0 \% ; \mathrm{Chi}^{2}=1.5 ; \mathrm{P}=\right.$ $0.68)$.

(iii) Twice-daily insulin plus oral hypoglycaemic agents In three comparisons, insulin monotherapy was compared with twice-daily (morning plus bedtime) premixed insulin 30/70 combined with SU (Bachmann 1988; Gutniak 1987; RavnikOblak 1995). Bachmann 1988 and Ravnik-Oblak 1995 reported HbA1(c) as median values. Gutniak 1987 and Bachmann 1988 found no statistically significant difference between monotherapy 
and combination therapy, and Ravnik-Oblak 1995 found a significant lower $\mathrm{HbA1c}$ for combination therapy $(\mathrm{P}<0.05)$.

(c) Multiple daily insulin injections (Comparison 03.01)

In two comparisons (Bastyr 1999; Yki-Järvinen 1992), a multiple insulin injection regimen (pre-meal soluble insulin with bedtime $\mathrm{NPH}$ ) was compared to bedtime NPH insulin combined with SU or SU plus metformin (comparison 03.01.01). Insulin-OHA combination therapy was associated with a non-significant mean (pooled weighted mean difference) lowering of HbA1c of $0.2 \%$ (95\% CI -0.4 to $0.1 ; \mathrm{P}=0.30$ ) compared to insulin monotherapy. There was no statistically significant heterogeneity $\left(\mathrm{I}^{2}=0 \%\right.$; $\mathrm{Chi}^{2}=$ $0.42 ; \mathrm{P}=0.48$ ).

In two comparisons, similar multiple injection regimens were compared with morning ultralente (Holman 1987) or NPH insulin (Yki-Järvinen 1992) combined with SU. In both studies mean decrease of $\mathrm{HbA} 1$ was not significantly different between regimens. One study compared a multiple insulin injection regimen with a matching multiple injection regimen combined with SU (Bastyr 1999). Mean decrease of HbAlc did not significantly differ between regimens.

\section{(d) Subgroup analyses}

In a subgroup analysis we combined studies that included metformin $( \pm$ SU) in insulin-OHA combination therapy (Chow 1995; Yki-Järvinen 1992; Yki-Järvinen 1999). (comparison 04.01) Of Yki-Järvinen 1999 we included the most successful of three comparisons, for which analysis was not pre-planned. No significant difference was found of insulin-OHA combination therapy over insulin monotherapy. This did not change after excluding one study of lower quality (Chow 1995).

(e) Sensitivity analyses

Since only published studies were included in this review preplanned analyses excluding unpublished trials were not performed. Repeating analyses excluding one large trial with poor quality (comparison 02.01.01) and another trial of poor quality (comparison 02.01 .03 and 04.01 ) did not significantly alter the results.

(f) Small study bias

For the outcome glycaemic control (HbA1(c)) we graphically evaluated a funnel plots of comparison 02.01. Visual assessment indicates small study bias (Funnel plot Figure 1). Other comparisons included too few studies for assessment of bias by funnel plots.

\section{HYPOGLYCAEMIA}

Hypoglycaemia was reported quantitatively or qualitatively in all but six studies (Fövényi 1997; Lundershausen 1987; Pontiroli 1990; Ravnik-Oblak 1995; Riddle 1989; Xu 2001). Heterogeneity in the definitions used between studies, and the quality of reporting of hypoglycaemia precluded the pooling of data. Of the fourteen studies (22 comparisons) that reported hypoglycaemia, in all but one comparison (Yki-Järvinen 1999), no significant difference in the frequency of hypoglycaemic events (symptomatic or biochemical) between insulin monotherapy and insulin-OHA combination therapy was demonstrated. Overall, only one episode of severe hypoglycaemia (requiring third party assistance) was reported (Wolffenbuttel 1996).

\section{(a) Once-daily insulin monotherapy regimens}

Hypoglycaemia rates were reported in some detail in six studies comparing a single daily injection of insulin applied in the evening (Holman 1987; Riddle 1989; Riddle 1992; Riddle 1998; Shank 1995; Sun 1995) to a matching insulin injection plus oral hypoglycaemic agents. No episodes of severe hypoglycaemia (requiring third party help) occurred. Riddle 1998 reported more frequent symptoms compatible with hypoglycaemia (though not confirmed biochemically) with combination therapy (51\% of patients) compared to insulin monotherapy $(37 \%)(\mathrm{P}<0.05)$, though the quicker rate of decline of HbA1c seen in the combination therapy group was considered an important factor by trial investigators. Non-statistically significant increases in hypoglycaemia with combination therapy were reported in two studies (Riddle 1992 $(($ mean $\pm S D) 8.8 \pm 6.6$ versus $6.9 \pm 6.6$ symptomatic hypoglycaemic events per patient), Shank $1995(0.1 \pm 0.2$ versus $0.2 \pm$ 0.3 hypoglycaemic episodes (blood glucose less than $3.89 \mathrm{mmol} / \mathrm{l}$ ) per patient per week. Sun 1995 reported one subject experiencing hypoglycaemic symptoms in each of the monotherapy and combination therapy groups. Riddle 1989 qualitatively reported similar rates of hypoglycaemia for both regimens. Holman 1987 reported a non-significant similar frequency of hypoglycaemia "sufficient to interrupt normal daily activities", occurring in six (40\%) of patients on once daily basal insulin and five $(33 \%)$ of those treated with sulphonylurea plus insulin.

\section{(b) Twice-daily insulin monotherapy regimens}

(i) Bedtime NPH insulin plus oral hypoglycaemic agents. Hypoglycaemia was reported in four studies with compared twicedaily insulin monotherapy to bedtime NPH insulin plus either sulphonylurea (1) (Wolffenbuttel 1996; Yki-Järvinen 1999), metformin (2) (Yki-Järvinen 1999), or sulphonylurea plus metformin (3) (Chow 1995; Yki-Järvinen 1992; Yki-Järvinen 1999).

\section{- Bedtime NPH insulin plus sulphonylurea}

Yki-Järvinen 1999 reported a similar frequency of symptomatic hypoglycaemic episodes over 12 months of therapy, affecting (mean \pm SD) $3.4 \pm 4.7$ patients treated with combination therapy versus $3.9 \pm 7.8$ treated with insulin alone. Fasting hypoglycaemic episodes (self-monitored fasting glucose less than $3.5 \mathrm{mmol} / \mathrm{l}$ ) were less common with twice daily insulin monotherapy (1.2\% of fasting glucose readings) than with sulphonylurea plus bedtime insulin $(2.2 \%)(\mathrm{P}<0.05)$. Wolffenbuttel 1996 reported only severe hypoglycaemia, which did not occur in either treatment arm.

\section{- Bedtime NPH insulin plus metformin}

One trial (Yki-Järvinen 1999) reported significantly less symptomatic ((mean \pm SD episodes per patient) $1.8 \pm 1.7$ versus 3.9 \pm 7.8 ) hypoglycaemic episodes with insulin plus metformin com- 
pared to insulin alone $(\mathrm{P}<0.05)$. Biochemical fasting hypoglycaemic episodes (less than $3.5 \mathrm{mmol} / \mathrm{l}$ ) were similar $1.1 \%$ versus $1.2 \%$ of measurements for insulin plus metformin and insulin monotherapy respectively.

- Bedtime NPH insulin plus sulphonylurea and metformin

Symptomatic hypoglycaemia rates were similar in three studies comparing twice daily insulin monotherapy to regimens with sulphonylurea plus metformin plus bedtime NPH insulin; Chow 1995 (mean \pm SD hypoglycaemic events per patient): 1.4 versus 1.0; Yki-Järvinen 1992: $4.0 \pm 5.5$ versus $1.0 \pm 5.3$; Yki-Järvinen 1999: $3.9 \pm 7.8$ versus $3.3 \pm 7.7$, for monotherapy versus combination therapy respectively (non-significant for each comparison). The frequency of low blood capillary glucose measurements was reported to be similar in one study (Yki-Järvinen 1992 (less than 4.0 $\mathrm{mmol} / \mathrm{l}$ ), though Yki-Järvinen 1999 reported significantly more fasting hypoglycaemia (less than $3.5 \mathrm{mmol} / \mathrm{l}$ ) with combination therapy compared to insulin monotherapy $(1.8 \%$ versus $1.2 \%$ respectively, for all fasting glucose measurements $(\mathrm{P}<0.01)$.

(ii) Morning NPH plus sulphonylurea

Yki-Järvinen 1992 reported non-significant similar rates of symptomatic hypoglycaemic events with monotherapy and combination therapy (mean \pm SD per patient) $4 \pm 5.5$ versus $3 \pm 5.7$ respectively. Wolffenbuttel 1996 reported a non-significant frequency of severe hypoglycaemia (requiring third party help), which over the study duration affected only one individual in the combination therapy group.

(iii) Twice-daily insulin plus sulphonylurea

Bachmann 1988 reported similar hypoglycaemia rates with both regimens ( $17 \%$ versus $20 \%$ of patients affected respectively (nonsignificant).

Gutniak 1987 reported more patients experiencing hypoglycaemia (glucose less than $3.5 \mathrm{mmol} / \mathrm{l}$ ) with combination therapy than monotherapy in the first two weeks of the study $(8.8 \%$ versus $4.1 \%, \mathrm{P}<0.002)$ though hypoglycaemia rates declined during the course of the study to $1.2 \%$ and $2.6 \%$ per week at three months (non-significant between groups). Overall hypoglycaemia rates for the entire study were not reported.

\section{(c) Multiple-daily insulin injections}

Three studies comparing a multiple insulin injection regimen (premeal soluble insulin with bedtime NPH) with bedtime NPH insulin plus sulphonylurea (Bastyr 1999; Holman 1987) or sulphonylurea plus metformin (Yki-Järvinen 1992) reported frequency of hypoglycaemia.

Symptomatic (Holman 1987; Yki-Järvinen 1992) and biochemical (Bastyr 1999 (blood glucose < $3.0 \mathrm{mmol} / \mathrm{l}$ ) hypoglycaemia was non-significantly less with combination therapy in all three studies; Holman 1987: 33\% versus $47 \%$ of patients affected; YkiJärvinen 1992: (mean \pm SD) $1 \pm 5.3$ versus $2 \pm 5.6$ episodes per patient; Bastyr 1999: $0.9 \pm 2.3$ versus $1.2 \pm 2.4$ events per patient per 30 days, for combination therapy and insulin monotherapy respectively (non-significant for each comparison).

Yki-Järvinen 1992 reported a similar frequency of biochemical hypoglycaemia $(<4.0 \mathrm{mmol} / \mathrm{l})$ with both regimens. Yki-Järvinen 1992 also compared the same multiple injection regimen to a combination of morning NPH insulin plus sulphonylurea. Symptomatic hypoglycaemia $(($ mean \pm SD) $3 \pm 5.7$ versus $2 \pm 5.6$ episodes per patient, for monotherapy and combination therapy respectively) and self monitored glucose values $<4.0 \mathrm{mmol} / \mathrm{l}$ were not significantly different between groups. No significant differences in 30-day hypoglycaemia rates were found by Bastyr 1999 who compared a multiple insulin injection regimen with sulphonylurea plus pre-meal soluble insulin. Mean \pm SD episodes of hypoglycaemia per patient per 30 days were $1.2 \pm 2.4$ versus $1.0 \pm$ 1.7 , respectively.

\section{INSULIN DOSE}

Insulin doses were titrated to predetermined glycaemic targets based on fasting ( \pm post prandial) or diurnal mean glucose values in fourteen studies; median fasting glucose target was less than $7.0 \mathrm{mmol} / \mathrm{l}$ (range: less than 5.6 to less than $10.1 \mathrm{mmol} / \mathrm{l}$ ) (Bachmann 1988; Chow 1995; Fövényi 1997; Gutniak 1987; Holman 1987; Lundershausen 1987; Riddle 1992; Riddle 1998; Shank 1995; Wolffenbuttel 1991; Wolffenbuttel 1996; Xu 2001; YkiJärvinen 1992; Yki-Järvinen 1999). Six studies did not formally report glucose targets to which insulin doses were titrated (Bastyr 1999; Lotz 1988; Pontiroli 1990; Ravnik-Oblak 1995; Riddle 1989; Sun 1995). Three studies utilised structured insulin titration algorithms based on self-measured fasting capillary glucose levels. Riddle 1992 commenced insulin at 30 units/day and increased the dose weekly by 20 units for mean fasting capillary glucose more than $10 \mathrm{mmol} / \mathrm{l}$, by 15 units for 7.8 to $10 \mathrm{mmol} / \mathrm{l}$, by 10 units 6.7 to $7.8 \mathrm{mmol} / \mathrm{l}$ and by 5 units for mean capillary glucose 5.6 to $6.7 \mathrm{mmol} / \mathrm{l}$. A reduction in insulin dose of 5 to 10 units was permitted for recurrent symptomatic or biochemical hypoglycaemia (less than $3.3 \mathrm{mmol} / \mathrm{l}$ ). Riddle 1998 commenced insulin at 10 units/day and increased the dose weekly by 10 units until fasting glucose was less than $7.8 \mathrm{mmol} / \mathrm{l}$ for two consecutive days, then by 5 units weekly until fasting glucose was less than $6.7 \mathrm{mmol} / \mathrm{l}$, aiming for a target fasting glucose 5.5 to $6.7 \mathrm{mmol} / \mathrm{l}$. Yki-Järvinen 1999 used a patient-led insulin self-titration titration regimen based on daily fasting glucose measurements. Starting insulin dose equalled capillary fasting glucose $(\mathrm{mmol} / \mathrm{l})$ and insulin doses were subsequently increased by 2 or 4 units, if three successive fasting glucose measurements were above 6 or $8 \mathrm{mmol} / \mathrm{l}$, respectively. Three studies restricted the maximum dose of insulin in combination regimens using once daily NPH insulin. Fövényi 1997 considered combination therapy unsuccessful if insulin requirements exceeded 40 units at bedtime, such patients were converted to twice daily insulin monotherapy. Chow 1995 limited the maximum daily dose of insulin for combination therapy and insulin monotherapy regimens to 26 and 84 units (or less than 1 unit/kg bodyweight) respectively. Furthermore, where the bed- 
time insulin dose exceeded 24 units, the insulin dose was apportioned between two daily injections. Lotz 1988 similarly limited the maximum dose of a single daily NPH insulin injection to 28 units.

Overall, insulin-oral hypoglycaemic agent combination therapy was associated with a weighted mean relative reduction in total daily insulin requirement of $46 \%$ (range: -5 to $74 \%$ ) compared to insulin monotherapy.

Compared with a single daily insulin injection, regimens combining a sulphonylurea with a matched daily insulin injection were associated with a $29 \%$ relative reduction in total daily insulin dose. Compared with twice daily insulin, combination regimens with bedtime NPH insulin were associated with relative reductions of $57 \%, 29 \%$ and $64 \%$, for sulphonylurea, metformin or both oral agents, respectively. Similarly, regimens combining morning NPH insulin with a sulphonylurea \pm metformin, and regimens utilizing twice daily insulin with sulphonylurea, were associated with relative reductions in total daily insulin dose of $43 \%$, and $42 \%$ respectively, compared to twice daily insulin monotherapy. In comparison with multiple daily insulin injections, combination regimens were also associated with a relative reduction in daily insulin requirement of $48 \%$.

\section{WELL-BEING, QUALITY OF LIFE AND TREATMENT SATISFACTION}

Two studies objectively assessed well-being, quality of life or treatment satisfaction. Chow 1995 used a visual analogue score (VAS) based, structured well-being questionnaire to assess subjective well-being and acceptability of insulin injections. Similar significant improvements in subjective well-being following the initiation of insulin therapy were noted with both insulin monotherapy and insulin-OHA combination therapy groups. However, significantly more patients in the combination therapy group wanted to continue insulin therapy at the end of the study ( $89 \%$ versus $76 \%$ for insulin monotherapy, $\mathrm{P}<0.0001$ ). Yki-Järvinen 1992 also assessed subjective well-being with questionnaires. Insulin therapy with all insulin treatment regimens was associated with significantly greater improvement in the subjective sense of well-being (74\%, 84\%, 100\% and $86 \%$ for the multiple insulin injection, $\mathrm{OHA}+$ morning NPH, OHA + evening NPH and twice-daily insulin mixture groups respectively) compared to the control group (41\% improvement $)(\mathrm{P}<0.001)$.

Wolffenbuttel 1991 and Wolffenbuttel 1996 qualitatively reported "improved well-being in nearly all patients", though methods for measuring well-being were not stated and no betweengroup comparisons were made.

\section{ADVERSE EFFECTS}

\section{WEIGHT GAIN}

Fifteen studies provided information on body weight outcomes (body weight or body mass index). Due to the heterogeneity of reported data and the absence of standard deviations of mean differences in most studies only the results of studies in three subgroups
(Comparison 02.02.01, Comparison 02.02.03 and Comparison 02.03.01) were pooled statistically.

(a) Once-daily insulin monotherapy regimens

Mean within-group change in weight from baseline was reported in four studies. Riddle 1992; Riddle 1998; Shank 1995 each found a non-significant trend to greater weight gain with insulin-sulphonylurea combination therapy compared to evening insulin alone (3.3 versus $3.9 \mathrm{~kg}$, 4 versus $4.3 \mathrm{~kg}, 0.6$ versus $4.5 \mathrm{~kg}$, insulin monotherapy versus combination therapy for each study, respectively). One cross-over study (Riddle 1989) reported significantly greater weight gain for patients when treated with insulin-OHA combination therapy (mean \pm SD) $2.6 \pm 1.8 \mathrm{~kg}$ ) compared to insulin alone $(0.6 \pm 2.2 \mathrm{~kg}, \mathrm{P}<0.01)$, though a significant confounding carry-over effect was observed, suggesting that the weight gain associated with each therapeutic intervention was affected by the order of treatment.

Holman 1987 found no significant difference in weight between groups at the end of each treatment period. Four studies (Lundershausen 1987; Pontiroli 1990; Sun 1995; Xu 2001) did not provide weight gain data.

(b) Twice-daily insulin monotherapy regimens

(i) Bedtime NPH insulin plus oral hypoglycaemic agents

- Bedtime NPH plus sulphonylurea (three comparisons) (Comparison 02.02.01)

Compared with insulin monotherapy, insulin-OHA combination therapy was associated with a non-significant (pooled weighted mean difference) $0.2 \mathrm{~kg}$ less weight gain (95\% CI: -0.2 to $0.6 ; \mathrm{P}=$ 0.3) (Fövényi 1997; Yki-Järvinen 1999). There was no statistically significant heterogeneity $\left(\mathrm{I}^{2}=0 \% ; \mathrm{P}=0.69\right)$. Wolffenbuttel 1996 reported a non-significant mean weight gain of $4 \mathrm{~kg}$ and $4.4 \mathrm{~kg}$ for insulin monotherapy and insulin-OHA combination therapy, respectively.

- Bedtime NPH plus metformin (one comparison)

Insulin-OHA combination therapy resulted in a significant mean $3.7 \mathrm{~kg}$ less weight gain compared to insulin monotherapy $(\mathrm{P}<$ 0.01) (Yki-Järvinen 1999).

- Bedtime NPH plus sulphonylurea and metformin (three comparisons) (Comparison 02.02.03)

Compared with insulin monotherapy, combination therapy was associated with a non-significant (pooled weighted mean difference) $1.5 \mathrm{~kg}$ less weight gain ( $95 \% \mathrm{CI}:-0.1$ to $3.2 ; \mathrm{P}=0.07)$. The test for heterogeneity was not significant $\left(\mathrm{Chi}^{2}=4.69 ; \mathrm{P}=0.1\right)$, although $\mathrm{I}^{2}$ test showed notable heterogeneity $\left(\mathrm{I}^{2}=57.3 \%\right)$ (Chow 1995; Yki-Järvinen 1992; Yki-Järvinen 1999).

(ii) Morning NPH insulin plus oral hypoglycaemic agents.

In one comparison, weight gain with insulin monotherapy was $0.4 \mathrm{~kg}$ less with monotherapy compared to combination therapy $(\mathrm{P}=0.57)$ (Yki-Järvinen 1992). Wolffenbuttel 1991 also reported 
similar weight gain with both regimens (mean weight gain $4.2 \mathrm{~kg}$ with monotherapy versus $3.9 \mathrm{~kg}$ with insulin/sulphonylurea (non significant). Lotz 1988 expressed weight data as percentage change in BROCA index, no significant between-group differences were found.

(iii) Twice-daily insulin plus oral hypoglycaemic agents.

Gutniak 1987 reported non-significantly greater weight gain with insulin-OHA combination therapy compared to insulin monotherapy. Ravnik-Oblak 1995 reported similar significant increases in (median) bodyweight (expressed absolute change in BMI) with both therapies. Data from Bachmann 1988 were disregarded since patients were withdrawn from this study if weight gain exceeded $3 \mathrm{~kg}$

\section{(c) Multiple-daily insulin injections}

Compared with insulin monotherapy, insulin-OHA combination therapy (Bastyr 1999; Yki-Järvinen 1992) was associated with a significant (pooled weighted mean difference) $1.1 \mathrm{~kg}$ less weight gain (95\% CI: 0.5 to $1.7 ; \mathrm{P}<0.001)$ (Comparison 02.03.01). Holman 1987 reported similar weight gain with both therapies. YkiJärvinen 1992 also compared multiple-daily insulin injections to sulphonylurea plus metformin and morning NPH insulin. Weight gain was non-significantly less with combination therapy. Bastyr 1999 reported non-significantly less weight gain with sulphonylurea combined with pre-meal soluble insulin compared to basalbolus insulin therapy.

\section{OTHER ADVERSE EFFECTS}

No studies assessed diabetes-related morbidity, mortality or total mortality, though two studies reported adverse events in some detail (Bastyr 1999; Riddle 1998). These studies reported no significant differences in frequency, or severity, of adverse events with insulin or combination therapy regimens. Gastrointestinal symptoms were not reported as an outcome measure in any study, though in one study (Yki-Järvinen 1999), side effects of metformin (diarrhoea, metallic taste, abdominal discomfort) necessitated study discontinuation for four patients randomised to receive metformin in conjunction with insulin (3 of 24) or insulin and sulphonylurea ( 1 of 24 patients).

\section{I S C U S S I O N}

\section{Summary of findings and limitations.}

This review was performed to assess the effects of insulin monotherapy compared with combinations of insulin with oral hypoglycaemic agents in patients with inadequate glycaemic control despite treatment with oral hypoglycaemic agents. Of 127 potentially relevant studies, 20 randomised clinical trials met the inclusion criteria for this review. These studies included a total of 1811 participants, and mean trial duration was 10 months. Participants had mean age of 59.8 years and mean known duration of diabetes of 9.6 years. Twenty-eight relevant comparisons were evaluated and categorised according to clinically relevant treatment schemes, based on both daily frequency and timing of insulin injections and class of oral hypoglycaemic agents used.

Significant clinical heterogeneity was observed in the inclusion criteria of individual studies with respect to oral hypoglycaemic agent(s) (and doses) used and the level of glycaemia required to determine oral agent failure (see table of included studies), reflecting a change in the use of oral hypoglycaemic agents over time, drug licensing regulations in different countries, and a more aggressive modern approach to the glycaemic management of type 2 diabetes.

Of the oral agents used in combination therapy regimens sulphonylureas were most frequently utilised (75\% of all comparisons), then sulphonylurea with metformin (21\%), and in one study (4\%) a combination regimen of metformin with insulin was used.

Overall study quality was poor (mean score 2.6 of maximal 7 points), and only five studies had adequate concealment of allocation. Most studies (85\%) had a follow-op time of less than one year, so the long-term effects on glycaemic control, diabetes-related complications, and other relevant outcomes are unclear. Except in one subcategory (comparison 02.01.01) statistically heterogeneity was low or moderate. The results of this review should be interpreted against the background of these limitations.

\section{Glycaemic control}

Glycaemic control was the main outcome measure in all studies. Of thirteen studies (21 comparisons) sufficient data could be extracted to calculate pooled effects on glycaemic control. The four crossover studies were not used for the analyses since phase-specific data were not available and wash-out periods were not used.

The results of this systematic review demonstrate no statistically significant benefits on glycaemic control with insulin monotherapy (two or more daily injections) versus oral hypoglycaemic agents combined with a single bedtime injection of neutral protamine Hagedorn (NPH) insulin, except for one study that included a combination therapy arm with insulin-metformin (Yki-Järvinen 1999). This study reported significantly better glycaemic control with insulin-metformin compared with other insulin-OHA combination regimens and also insulin monotherapy. Compared with insulin-sulphonylurea, insulin-metformin combination therapy resulted in a significantly greater improvement in HbA1c of $0.6 \%(-1.9 \pm 1.4$ versus $-2.5 \pm 1.7, \mathrm{P}<0.05)$. This is also of clinical significance in light of the UKPDS (UKPDS 33) which, with a $0.9 \%$ difference in $\mathrm{HbA1c}$ between intensively-treated and conventionally-treated patients, reported a statistically significant relative risk reduction in microvascular disease of $25 \%$. It should be noted however that in this study (Yki-Järvinen 1999), analysis was not as per intention-to-treat and only 19 of 24 (79\%) patients randomised to receive insulin-metformin completed the study. Besides, the insulin saving effect of sulphonylurea was lost. Therefore the results of this study should be interpreted with caution. 
Insulin-OHA combination therapy provided statistically significantly lower HbA1c (pooled difference of $0.3 \%$ ) compared with insulin monotherapy when the latter was applied as a once-daily injection of NPH insulin. Conversely, twice-daily insulin monotherapy (NPH or mixed insulin) provided lower HbA1c (pooled difference $0.4 \%$ ) to insulin-OHA combination therapy only if insulin was given as a single morning injection. Since these regimens are infrequently currently used in the management of type 2 diabetes, conclusions drawn from these results are limited. Besides, in both cases the weighted mean differences between the two insulin schemes were small and, although statistically significant, less clinically relevant.

These results do suggest that present-day combination therapy regimens provide at least comparable glycaemic control compared to insulin monotherapy. This is relevant for daily diabetes care, since the simple addition of bedtime NPH insulin to oral hypoglycaemic agents (metformin \pm sulphonylurea) may allow physicians and patients to overcome a possible resistance to the use of insulin. Moreover, from a clinical standpoint the beneficial insulin sparing effects of oral agents could be maintained. In this respect the continuation of sulphonylurea is more beneficial than the continuation of metformin. Opponents to bedtime NPH insulin-OHA combination therapy suggest that glycaemic control remains suboptimal with this approach (Westphal 2003), however, the results of this review demonstrate that insulin monotherapy fares no better with respect to glycaemic control. This is of particular relevance to elderly patients where the inherent risk of hypoglycaemia may outweigh the benefits of tight glycaemic control.

\section{Quality of life}

Quality of life related issues were investigated in only four studies, so this review could not be conclusive regarding quality of life. In general, these studies reported improved well-being with both insulin monotherapy and insulin-OHA combination regimens, with no significant differences between groups.

\section{Insulin dose}

In seventy percent of the studies insulin doses were titrated to predetermined glycaemic targets based on fasting or diurnal mean glucose values (median fasting glucose target less than $7.0 \mathrm{mmol} / \mathrm{l}$; range 5.6 to $10.1 \mathrm{mmol} / \mathrm{L})$. In less than half $(45 \%)$ of the studies were patients instructed to measure blood glucose levels at home. Three studies restricted the maximum dose of insulin in combination regimens using once-daily NPH insulin (range 26 to $40 \mathrm{IU}$ ). Overall, insulin-OHA combination therapy was associated with a relative reduction in total daily insulin requirement of $46 \%$ compared to insulin monotherapy (all schemes). This figure reflects the insulin saving capacity of oral hypoglycaemic agents when combined with insulin. However, compared with twice-daily or multiple injection monotherapy regimens, the insulin-sparing effect of a sulphonylurea whether or not combined with metformin seemed to be superior to that of metformin alone ( $-50 \%$ versus
$29 \%$ ), although the latter figure was based on data from a solitary study (Yki-Järvinen 1999).

\section{Hypoglycaemia}

Hypoglycaemia was reported quantitatively or qualitatively in all but five studies (Fövényi 1997; Lundershausen 1987; Pontiroli 1990; Ravnik-Oblak 1995; Xu 2001) Heterogeneity in the definitions used between studies, and the quality of reporting of hypoglycaemia precluded the pooling of data. Of the fourteen studies (22 comparisons) that reported hypoglycaemia, all but one (comparison 02.01.02) (Yki-Järvinen 1999) demonstrated no statistically significant difference in the frequency of hypoglycaemic events (symptomatic or biochemical) between insulin monotherapy and insulin-OHA combination therapy. Overall, only one episode of severe hypoglycaemia (requiring third party assistance) was reported (Wolffenbuttel 1996).

\section{Weight gain}

Of 10 studies (13 comparisons) sufficient data could be extracted to calculate pooled effects on body weight. Overall, the results of this review suggest that insulin-OHA combination therapy resulted in statistically significant less weight gain compared with insulin monotherapy provided that NPH insulin was applied at bedtime and metformin was used as a single agent or in combination with a sulphonylurea. In all other comparisons no significant differences with respect to weight gain were detected between monotherapy and combination therapy regimens. Metformin reduces insulin requirement and may also prevent weight gain, even in combination with a sulphonylurea or intensive insulin treatment. However, only one study included a treatment arm with insulin in combination with metformin alone. Whether metformin should be used as a single agent, or applied in conjunction with other oral agents in insulin combination regimens remains unclear.

\section{Adverse effects}

Very few studies in this review systematically reported adverse effects of oral agents or insulin in detail. Withdrawal of patients due to side-effects of oral medication (e.g. gastrointestinal symptoms of metformin use) appeared minimal.

\section{Limitations}

Overall, study quality was low (mean score 2.6 (range 0 to 7 ), and no study included a power calculation. The majority of studies had small sample size and limited follow-up and were therefore unable to report on hard end-points. Of the studies included in this review, combination regimens utilising oral hypoglycaemic agents with a single bedtime injection of NPH insulin provided comparable glycaemic control to any insulin monotherapy regimen, though the long-term success of such regimens remains unclear.

Wolffenbuttel 1996 reported that after six months of treatment, $32 \%$ of patients in the sulphonylurea-bedtime neutral protamine Hagedorn (NPH) insulin arm required a second injection at morning time to control glycaemia. Similarly, Fövényi 1997 reported 
that $40.5 \%$ of patients at 12 months, and $58.2 \%$ of patients at three years, required conversion to conventional insulin therapy because of inadequate glycaemic control, though combination therapy was considered unsuccessful if the dose of bedtime NPH insulin required to suppress fasting glucose to less than $7.0 \mathrm{mmol} / \mathrm{L}$ exceeded 40 units. Chow 1995 divided the bedtime insulin between two daily injections when the total daily insulin requirement exceeded 24 units. Yki-Järvinen 1999 however, using a patient led structured insulin dose titration regimen targeting fasting glycaemia, reported that individual bedtime NPH insulin dose required to achieve fasting glucose values less than $6.0 \mathrm{mmol} / \mathrm{L}$ ranged from 8 to 168 units, suggesting that some patients in other studies may have been unnecessarily converted to conventional insulin regimens. This regimen was associated with a low drop-out rate; over one year of treatment no patients withdrew due to lack of efficacy of treatment.

Three studies attempted to identify criteria that predicted a good response to combination therapy. Ravnik-Oblak 1995 reported that those who responded well to combination therapy had a shorter duration of diabetes, greater bodyweight and a higher basal C-peptide at baseline, to those who responded poorly. However, age, diabetes duration, BMI, glycaemia, peripheral insulin resistance or ß-cell insulin secretory capacity were not useful predictors. Chow 1995 and Riddle 1989 also found no correlation between these baseline values and future success of combination therapy, in addition to prior oral hypoglycaemic therapy and initial lipid sub-fractions.

No published studies have directly compared bedtime insulin regimens with oral hypoglycaemic agents combined with long-acting insulin analogues to insulin monotherapy, although two large studies (Riddle 2003 ( $\mathrm{n}=756$ ); Yki-Järvinen $2000(\mathrm{n}=426)$ ) have compared combination regimens with oral hypoglycaemic agents and bedtime NPH insulin versus insulin glargine over 24 and 52 weeks respectively. In both studies, similar levels of glycaemic control were achieved with both regimens, though with significantly less nocturnal hypoglycaemia with insulin glargine. Using a forced insulin titration regimen, Riddle 2003 systematically titrated insulin doses on a weekly basis to achieve fasting plasma glucose levels of less than $5.5 \mathrm{mmol} / \mathrm{L}$. Both regimens achieved a mean $\mathrm{HbA1c}$ at 24 weeks of less than $7.0 \%$ (6.96\% (glargine) versus $6.97 \%(\mathrm{NPH})$, reference range 4 to $6 \%$ ).

\section{A U THORS'CONCLUSIONS}

\section{Implications for practice}

Combination therapy regimens with oral hypoglycaemic agents (sulphonylurea \pm metformin) and bedtime neutral protamine Hagedorn (NPH) insulin provide comparable glycaemic control to insulin monotherapy for insulin-requiring patients with type 2 diabetes. Weight gain appears less if metformin is used. In one study (Yki-Järvinen 1999), bedtime NPH-insulin combined with metformin provided clinically and statistically significantly superior glycaemic control to analogous regimens with sulphonylurea, sulphonylurea with metformin, and to twice-daily insulin monotherapy, suggesting that this regimen may be the treatment of choice, although inherent study limitations (small sample size, significant drop-out rate) necessitates further research for clarification of this point. Compared to insulin monotherapy, insulinOHA combination therapy is associated with a reduction in insulin requirement of approximately $46 \%$, with sulphonylureas exerting a greater insulin-sparing capacity than metformin alone.

The results of this review are relevant for daily diabetes care, since the simple addition of a single daily insulin injection to oral agents (metformin alone or in addition to sulphonylurea) may allow physicians and patients to overcome a possible resistance to initiate insulin and moreover, from a clinical standpoint, the beneficial insulin sparing effects of oral agents could be maintained with minimisation of weight gain.

The question whether insulin therapy in type 2 diabetes should be applied as monotherapy, or in addition to oral agents (combination therapy) is still a subject for debate (Garber 2003, Westphal 2003). Guidelines on type 2 diabetes are conflicting about indications, regimen, and dosages of the possible treatment regimens, and most recommendations are not based on clear evidence (Burgers 2002). Overall, the results of this review are in accordance with the findings of other reviews (Pugh 1992, Johnson 1996, Yki-Järvinen 2001). We found no evidence that insulin monotherapy (applied as a two or more injection scheme) is superior to a single bedtime injection of NPH insulin in addition to a common oral agent regimen over the duration of the trials studied. Therefore, insulinOHA combination therapy should be considered a suitable simple starting point for most insulin-requiring type 2 diabetes patients. Since both physicians and patients are often inclined to delay the start with insulin, such a strategy might encourage the timely use of insulin (Riddle 2002). Presently, due to lack of studies it remains unclear whether such regimens with metformin alone are superior to the combination with a sulphonylurea.

\section{Implications for research}

More studies are required to determine the optimal combination of antidiabetic agents for this category of patients. These studies should focus on hard endpoints as (diabetes-related) morbidity and mortality, treatment satisfaction, quality of life and general wellbeingincluding, and safety aspects of the different combination regimens (e.g. sulphonylureas and metformin), should be larger with respect to number of patients, and have longer follow-up. These studies should also include newer oral agents (e.g. meglitinides, thiazolidinediones). Further research on this issue should assess also the possible long-term benefits over NPH insulin of recently introduced long-acting insulin analogues (Riddle 2003).

Further research should address the following questions: 
- Is insulin-OHA combination therapy with metformin preferable to sulphonylurea plus metformin?

- Is there a ceiling effect for insulin dose in insulin-OHA combination therapy, above which there is little / no benefit?

- Can failure on insulin-OHA combination therapy be predicted from patient characteristics at baseline?

- What are the effects of long-acting insulin analogues (glargine, detemir) versus NPH insulin when combined with oral hypoglycaemic agents?

- What insulin schemes are preferred by patients, and do they affect quality of life and general well-being?

\section{POTENTIAL CONFLICT OF}

\section{N T E R ES T}

In 1999 ANG has received an unrestricted research grant from Novo Nordisk for conducting studies on monitoring and treatment of patients with type 2 diabetes in primary care.

Research conducted by NJF during 1999-2001 was supported by an unrestricted research grant from Novo Nordisk.

\section{ACKNOWLEDGEMENTS}

We thank the authors Francis Chow, József Fövényi, Rury Holman, and Antonio Pontiroli who kindly provided unpublished information.

\section{SOURCES OF SUPPORT}

\section{External sources of support}

- No sources of support supplied

Internal sources of support

- Julius Center for Health Science and Primary Care NETHERLANDS 


\section{R E F E R E N C E S}

\section{References to studies included in this review}

Bachmann 1988 \{published data only\}

Bachmann W, Lotz N, Mehnert H, Rosak C, Schoffling K. [Effectiveness of combined treatment with glibenclamide and insulin in secondary sulfonylurea failure. A controlled multicenter doubleblind clinical trial]. Deutsche Medizinische Wochenschrift 1988;113 (16):631-36. 3832 .

Bastyr 1999 \{published data only\}

Bastyr EJ, Johnson ME, Trautmann ME, Anderson JH, Vignati L. Insulin lispro in the treatment of patients with type 2 diabetes mellitus after oral agent failure. Clinical Therapeutics 1999;21(10):1703-14.

Chow 1995 \{published and unpublished data\}

Chow CC, Tsang LW, Sorensen JP, Cockram CS. Comparison of insulin with or without continuation of oral hypoglycemic agents in the treatment of secondary failure in NIDDM patients. Diabetes Care 1995;18(3):307-14.

Fövényi 1997 \{published and unpublished data\} Fövényi J, Grosz A, Thaisz E, Lehotkai, L, Sallai T, Kocsis G. [Daytime sulfonyluyrea - bedtime insulin combination therapy in Type II diabetes]. Magy Belorv Arch (Hungarian Archive of Internal Medicine) 1997;50:607-13.

Gutniak 1987 \{published data only\} Gutniak M, Karlander SG, Efendic S. Glyburide decreases insulin requirement, increases beta-cell response to mixed meal, and does not affect insulin sensitivity: effects of short- and long-term combined treatment in secondary failure to sulfonylurea. Diabetes Care 1987; 10(5):545-54

Holman 1987 \{published data only\}

Holman RR, Steemson J, Turner RC. Sulphonylurea failure in type 2 diabetes: treatment with a basal insulin supplement. Diabetic Medicine 1987;4(5):457-62.

Karlander 1991 \{published data only\} Karlander SG, Gutniak MK, Efendic S. Effects of combination therapy with glyburide and insulin on serum lipid levels in NIDDM patients with secondary sulfonylurea failure. Diabetes Care 1991;14 (11):963-67.

Lotz 1988 \{published data only\}

Lotz N, Bachmann W, Ladik T, Mehnert H. [Combination therapy with insulin/sulfonylurea in the long-term therapy of type II diabetes following "secondary failure"]. [German]. Klinische Wochenschrift 1988;66(21):1079-84.

Lundershausen 1987 \{published data only\}

Lundershausen R, Orban S, Pissarek D, Panzram G. [Long-term effect of combination glibenclamide-insulin treatment in the secondary failure of sulfonylurea therapy--results of a one-year double blind study]. [German]. Wiener Klinische Wochenschrift 1987;99(17):6038 .

Mäkimattila 1999 \{published data only\}

Mäkimattila S, Nikkila K, Yki-Järvinen $\mathrm{H}$. Causes of weight gain during insulin therapy with and without metformin in patients with Type II diabetes mellitus. Diabetologia 1999;42(4):406-12.
Pontiroli 1990 \{published and unpublished data\} Pontiroli AE, Dino G, Capra F, Pozza G. Combined therapy with glibenclamide and ultralente insulin in lean patients with NIDDM with secondary failure of sulfonylureas. Follow up at two years. $D i$ abete et Metabolisme 1990;16(4):323-27.

Ravnik-Oblak 1995 \{published data only\}

Ravnik-Oblak M, Mrevlje F. Insulin versus a combination of insulin and sulfonylurea in the treatment of NIDDM patients with secondary oral failure. Diabetes Research \& Clinical Practice 1995;30 (1):27-35.

Riddle 1989 \{published data only\}

Riddle MC, Hart JS, Bouma DJ, Phillipson BE, Youker G. Efficacy of bedtime NPH insulin with daytime sulfonylurea for subpopulation of type II diabetic subjects. Diabetes Care 1989;12(9):623-29. 1.

Riddle 1992 \{published data only\}

Riddle M, Hart J, Bingham P, Garrison C, McDaniel P. Combined therapy for obese type 2 diabetes: suppertime mixed insulin with daytime sulfonylurea. American Journal of the Medical Sciences 1992; 303(3):151-56

Riddle 1998 \{published data only\} Riddle MC, Schneider J. Beginning insulin treatment of obese patients with evening 70/30 insulin plus glimepiride versus insulin alone. Glimepiride Combination Group. Diabetes Care 1998;21(7): 1052-57.

Shank 1995 \{published data only\}

Shank ML, Del Prato S, DeFronzo RA. Bedtime insulin/daytime glipizide. Effective therapy for sulfonylurea failures in NIDDM. $D i$ abetes 1995;44:165-72.

Sun 1995 \{published data only\}

Sun Y, Xiong Y, Yang J. [The effectiveness of combined insulin and sulfonylurea in treating non-insulin dependent diabetic patients]. [Chinese]. Chung-Hua Nei Ko Tsa Chih Chinese Journal of Internal Medicine 1995;34(4):246-49

Wolffenbuttel 1991 \{published data only\} Wolffenbuttel BH, Rondas-Colbers GJ, Menheere PP, Sels JP, Nieuwenhuijzen-Kruseman AC. [The effects of insulin combined with glibenclamide on glucose and lipid metabolism in patients with Type II diabetes mellitus]. Ned Tijdschr Geneeskd 1991;135:108084.

Wolffenbuttel 1996 \{published data only\}

Wolffenbuttel BH, Sels JP, Rondas-Colbers GJ, Menheere PP, Nieuwenhuijzen-Kruseman AC. Comparison of different insulin regimens in elderly patients with NIDDM. Diabetes Care 1996;19 1326-32.

Xu 2001 \{published data only\}

Xu WC, Chen CR, Chen YS. Combination therapy with bedtime insulin and daytime oral hypoglycaemic agents in type 2 diabetic patients [Chinese]. Hebei Medicine 2001;23:23-24. 7231.

Yki-Järvinen 1992 \{published data only\}

* Yki-Järvinen H, Kauppila M, Kujansuu E, Lahti J, Marjanen T, Niskanen L, et al. Comparison of insulin regimens in patients with non-insulin-dependent diabetes mellitus. New England Journal of Medicine 1992;327(20):1426-33. 
Yki-Järvinen 1999 \{published data only\}

* Yki-Järvinen H, Ryysy L, Nikkila K, Tulokas T, Vanamo R, Heikkila M. Comparison of bedtime insulin regimens in patients with type 2 diabetes mellitus. A randomized, controlled trial. Annals of Internal Medicine 1999;130(5):389-96.

\section{References to studies excluded from this review Allen 1985}

Allen BT, Feinglos MN, Lebovitz HE. Treatment of poorly regulated non-insulin-dependent diabetes mellitus with combination insulinsulfonylurea. Arch Intern Med 1985;145(10):1900-03.

\section{Aviles 1999}

Aviles-Santa L, Sinding J, Raskin P. Effects of metformin in patients with poorly controlled, insulin-treated type 2 diabetes mellitus. A randomized, double-blind, placebo-controlled trial. Annals of Internal Medicine 1999;131(3):182-88.

\section{Bastyr 2000}

Bastyr EJ, Stuart CA, Brodows RG, Schwartz S, Graf CJ, Zagar A, et al. Therapy focused on lowering postprandial glucose, not fasting glucose, may be superior for lowering HbA1c. IOEZ Study Group. [see comments]. Diabetes Care 2000;23(9):1236-41.

Bieger 1984

Bieger WP, Dlugosch R, Rettenmeier A, Holler HD, Bert H, Schwarz $\mathrm{W}$, et al. Trial of sulfonylurea in combination with insulin in the therapy of diabetes type I and II. Evidence against a primary extrapancreatic receptor effect. Klinische Wochenschrift 1984;62(13):631-39.

\section{Birkeland 1994}

Birkeland KI, Hanssen KF, Urdal P, Berg K, Vaaler S. A long-term, randomized, comparative study of insulin versus sulfonylurea therapy in type 2 diabetes [see comments]. Journal of Internal Medicine 1994; 236:305-13.

\section{Birkeland 1996}

Birkeland KI, Rishaug U, Hanssen KF, Vaaler S. NIDDM: a rapid progressive disease. Results from a long-term, randomised, comparative study of insulin or sulphonylurea treatment. Diabetologia 1996; 39:1629-33.

\section{Bruns 1988}

Bruns W, Willkommen G, Philipp A, Czeczatka W, Hildebrandt R, Jutzi E. Zur Behandlung von Typ II (non-insulin-dependent)-Diabetikern mit Sulfonylharnstoff-Sekundärversagen Kombinationstherapie von Glibenclamid und Insulin. Zeitschrift für Klinische Medizin 1988;43:625-29. 7232.

Calle 1995

Calle-Pascual AL, Garcia HJ, Martin-Alvarez PJ, Vara E, Calle JR, Munguira ME, et al. Comparison between acarbose, metformin, and insulin treatment in type 2 diabetic patients with secondary failure to sulfonylurea treatment. Diabetes and Metabolism 1995;21:256-60.

\section{Camerini 1994}

Camerini-Davalos RA BJJV. Effect of insulin-glipizide combination on skeletal muscle capillary basement membrane width in diabetic patients. Clinical Therapeutics 1994;16(6):952-61.

Carta 1984

Carta Q, Trovati M, Dani F, Caselle MT, Vitali S, Cavalot F, et al. [Insulin or insulin + oral hypoglycemic drugs in the treatment of type 2 diabetes difficult to compensate metabolically?]. [Italian]. Minerva Endocrinologica 1984;9(2):241-45.

\section{Casner 1988}

Casner PR. Insulin-glyburide combination therapy for non-insulindependent diabetes mellitus: a long-term double-blind, placebo-controlled trial. Clinical Pharmacology \& Therapeutics 1988;44(5):594603.

Castillo 1987

Castillo M, Scheen AJ, Paolisso G, Lefebvre PJ. The addition of glipizide to insulin therapy in type-II diabetic patients with secondary failure to sulfonylureas is useful only in the presence of a significant residual insulin secretion. Acta Endocrinologica 1987;116(3):364-72.

\section{Chazan 2001}

Chazan AC, Gomes MB. Gliclazide and bedtime insulin are more efficient than insulin alone for type 2 diabetic patients with sulfonylurea secondary failure. Brazilian Journal of Medical \& Biological Research 2001;34(1):49-56.

\section{Chiasson 1994}

Chiasson JL, Josse RG, Hunt JA, Palmason C, Rodger NW, Ross SA. The efficacy of acarbose in the treatment of patients with non-insulindependent diabetes mellitus. A multicenter controlled clinical trial. Annals of Internal Medicine 1994;121(12):928-35. 27.

\section{Clauson 1996}

Clauson P, Karlander S, Steen L, Efendic S. Daytime glibenclamide and bedtime NPH insulin compared to intensive insulin treatment in secondary sulphonylurea failure: a 1-year follow-up. Diabetic Medicine 1996;13(5):471-77.

\section{Cortes 1993}

Cortes AH, Espinosa Lopez FR, Angulo Cervera JA, Diaz TJ. [A comparative study of insulin and glyburide versus glyburide or insulin in the chronic control of patients with type-2 diabetes]. [Spanish]. Gaceta Medica de Mexico 1993;129(6):383-86.

\section{Diehl 1985}

Diehl AK, Sugarek NJ, Bauer RL. Medication compliance in noninsulin-dependent diabetes: a randomized comparison of chlorpropamide and insulin. Diabetes Care 1985;8:219-23.

\section{Elgrably 1991}

Elgrably F, Costagliola D, Chwalow AJ, Varenne P, Slama G, Tchobroutsky G. Initiation of insulin treatment after 70 years of age: patient status 2 years later. Diabet Med 1991;8(8):773-77. 3682

\section{Falko 1985}

Falko JM, Osei K. Combination insulin/glyburide therapy in type II diabetes mellitus. Effects on lipoprotein metabolism and glucoregulation. American Journal of Medicine 1985;79(3B):92-101.

\section{Feinglos 1997}

Feinglos MN, Thacker CH, English J, Bethel MA, Lane JD. Modification of postprandial hyperglycemia with insulin lispro improves glucose control in patients with type 2 diabetes. Diabetes Care 1997; 20(10):1539-42.

\section{Feinglos 1998}

Feinglos MN, Thacker CR, Lobaugh B, DeAtkine DD, McNeill DB, English JS. Combination insulin and sulfonylurea therapy in insulinrequiring type 2 diabetes mellitus. Diabetes Research \& Clinical Practice 1998;39(3):193-99.

\section{Firth 1986}

Firth RG, Bell PM, Rizza RA. Effects of tolazamide and exogenous insulin on insulin action in patients with non-insulin-dependent di- 
abetes mellitus. The New England Journal of Medicine 1986;314: $1280-86$.

\section{Firth 1987}

Firth R, Bell P, Marsh M, Rizza RA. Effects of tolazamide and exogenous insulin on pattern of postprandial carbohydrate metabolism in patients with non-insulin- dependent diabetes mellitus. Results of randomized crossover trial. Diabetes 1987;36:1130-38.

\section{Fonseca 2000}

Fonseca V, Foyt HL, Shen K, Whitcomb R. Long-term effects of troglitazone: open-label extension studies in type 2 diabetic patients. Diabetes Care 2000;23(3):354-59. 7231.

\section{Fritsche 2000}

Fritsche A, Schmulling RM, Haring HU, Stumvoll M. Intensive insulin therapy combined with metformin in obese type 2 diabetic patients. Acta Diabetologica 2000;37(1):13-18.

\section{Giugliano 1993}

Giugliano D, Quatraro A, Consoli G, Minei A, Ceriello A, De Rosa $\mathrm{N}$, et al. Metformin for obese, insulin-treated diabetic patients: improvement in glycaemic control and reduction of metabolic risk factors. European Journal of Clinical Pharmacology 1993;44(2):107-12. 4664.

\section{Groop 1984}

Groop L, Harno K, Tolppanen EM. The combination of insulin and sulphonylurea in the treatment of secondary drug failure in patients with type II diabetes. Acta Endocrinologica 1984;106(1):97-101.

\section{Groop 1985}

Groop L, Harno K, Nikkila EA, Pelkonen R, Tolppanen EM. Transient effect of the combination of insulin and sulfonylurea (glibenclamide) on glycemic control in non-insulin dependent diabetics poorly controlled with insulin alone. Acta Medica Scandinavica 1985;217(1):33-39.

\section{Groop 1989}

Groop L, Widen E, Franssila-Kallunki A, Ekstrand A, Saloranta C, Schalin, C, et al. Different effects of insulin and oral antidiabetic agents on glucose and energy metabolism in type 2 (non-insulindependent) diabetes mellitus. Diabetologia 1989;32(8):599-605.

\section{Groop 1991}

Groop L, Widen E. Treatment strategies for secondary sulfonylurea failure. Should we start insulin or add metformin? Is there a place for intermittent insulin therapy?. Diabete et Metabolisme 1991;17(1 Pt 2):218-23.

\section{Groop 1992}

Groop LC, Widen E, Ekstrand A, Saloranta C, Franssila-Kallunki A, Schalin-Jantti C, et al. Morning or bedtime NPH insulin combined with sulfonylurea in treatment of NIDDM. Diabetes Care 1992;15 (7):831-34

Guvener 1999

Guvener N, Gedik O. Effects of combination of insulin and acarbose compared with insulin and gliclazide in type 2 diabetic patients. Acta Diabetologica 1999;36(1-2):93-97.

\section{Hamelbeck 1982}

Hamelbeck H, Klein W, Zoltobrocki M, Schoffling K. [Glibenclamide-insulin combination in the management of secondary failure of sulfonyl-urea medication]. Deutsche Medizinische Wochenschrift 1982;107(42):1581-83. 7230.

\section{Hirsch 1999}

Hirsch IB. Metformin added to insulin therapy in poorly controlled type 2 diabetes. Diabetes Care 1999;22(5):854.

Josse 1995

Josse RG. Acarbose for the treatment of type II diabetes: the results of a Canadian multi-centre trial. [erratum appears in Diabetes Res Clin Pract 1995 Sep;29(3):215]. Diabetes Research \& Clinical Practice 1995;28 Suppl:S167-S172.

\section{Kasim 1986}

Kasim SE, LeBoeuf RC, Rockett MJ, Page J, Keyser AJ. The effects of oral agent or insulin treatments on the plasma lipoproteins and the plasma lipoprotein lipase activator in diabetic patients. Hormone \& Metabolic Research 1986;18(3):190-93.

\section{Kelley 1998}

Kelley DE, Bidot P, Freedman Z, Haag B, Podlecki D, Rendell M, et al. Efficacy and safety of acarbose in insulin-treated patients with type 2 diabetes. Diabetes Care 1998;21(12):2056-61. 49.

\section{Kitabchi 1987}

Kitabchi AE, Soria AG, Radparvar A, Lawson-Grant V. Combined therapy of insulin and tolazamide decreases insulin requirement and serum triglycerides in obese patients with noninsulin-dependent diabetes mellitus. American Journal of the Medical Sciences 1987;294 (1):10-14.

\section{Klein 1991}

Klein W. Sulfonylurea-metformin-combination $</$ strong $>$ versus sulfonylurea-insulin-combination $</ s$ trong $>$ in secondary failures of sulfonylurea monotherapy. Results of a prospective randomized study in 50 patients. Diabete et Metabolisme 1991;17(1 Pt 2):235-40.

\section{Kyllastinen 1985}

Kyllastinen M, Groop L. Combination of insulin and glibenclamide in the treatment of elderly non-insulin dependent (type 2) diabetic patients. Annals of Clinical Research 1985;17(3):100-04.

\section{Landstedt 1995}

Landstedt-Hallin L, Adamson U, Arner P, Bolinder J, Lins PE. Comparison of bedtime NPH or preprandial regular insulin combined with glibenclamide in secondary sulfonylurea failure. Diabetes Care 1995;18(8):1183-86. 38.

\section{Landstedt 1999}

Landstedt-Hallin L, Arner P, Lins PE, Bolinder J, Olsen H, Groop L. The role of sulphonylurea in combination therapy assessed in a trial of sulphonylurea withdrawal. Scandinavian Insulin-Sulphonylurea Study Group Research Team. Diabetic Medicine 1999;16(10):82734.

\section{Lardinois 1985}

Lardinois CK, Liu GC, Reaven GM. Glyburide in non-insulin-dependent diabetes. Its therapeutic effect in patients with disease poorly controlled by insulin alone. Archives of Internal Medicine 1985;145 (6): 1028-32.

\section{Lawrence 1988}

Lawrence AM, Abraira C. New modalities in diabetes treatment. The American journal of medicine 1988;85:153-58.

\section{Lebovitz 1990}

Lebovitz HE, Pasmantier R. Combination insulin-sulfonylurea therapy. Diabetes Care 1990;13(6):667-75. 6429. 


\section{Lewitt 1989}

Lewitt MS, Yu VK, Rennie GC, Carter JN, Marel GM, Yue DK, et al. Effects of combined insulin-sulfonylurea therapy in type II patients. [see comments]. Diabetes Care 1989;12(6):379-83.

\section{Liedtke 1990}

Liedtke RK SMM. Transdermal insulin application in type II diabetic patients. Results of a clinical pilot study. Arzneimittel-Forschung Drug Research 1990;40(8):884-86.

\section{Lindstrom 1992}

Lindstrom T, Arnqvist HJ, Ludvigsson J, von Schenck HH. C-peptide profiles in patients with non-insulin-dependent diabetes mellitus before and during insulin treatment. Acta Endocrinologica 1992;126 (6):477-83.

\section{Lindstrom 1999}

Lindstrom T, Nystrom FH, Olsson AG, Ottosson AM, Arnqvist HJ. The lipoprotein profile differs during insulin treatment alone and combination therapy with insulin and sulphonylureas in patients with Type 2 diabetes mellitus. Diabetic Medicine 1999;16(10):82026.

\section{Lins 1988}

Lins PE, Lundblad S, Persson-Trotzig E, Adamson U. Glibenclamide improves the response to insulin treatment in non-insulin-dependent diabetics with second failure to sulfonylurea therapy. Acta Medica Scandinavica 1988;223(2):171-79.

\section{Longnecker 1986}

Longnecker MP, Elsenhans VD, Leiman SM, Owen OE, Boden G. Insulin and a sulfonylurea agent in non-insulin-dependent diabetes mellitus. Archives of Internal Medicine 1986;146(4):673-76.

\section{Lopez 1999}

Lopez-Alvarenga JC, Aguilar-Salinas CA, Velasco-Perez ML, AritaMelzer O, Guillen LE, Wong B, et al. Acarbose vs. bedtime NPH insulin in the treatment of secondary failures to sulphonylureametformin therapy in type 2 diabetes mellitus. Diabetes Obesity \& Metabolism 1999;1(1):29-35.

\section{Martin 1986}

Martin DB. Type II diabetes: insulin versus oral agents. New England Journal of Medicine 1986;314(20):1314-15.

\section{Mauerhoff 1986}

Mauerhoff T, Ketelslegers JM, Lambert AE. Effect of glibenclamide in insulin-treated diabetic patients with a residual insulin secretion. Diabete et Metabolisme 1986;12(1):34-38.

\section{Mezitis 1992}

Mezitis NH, Heshka S, Saitas V, Bailey TS, Costa R, Pi-Sunyer FX. Combination therapy for NIDDM with biosynthetic human insulin and glyburide. Diabetes Care 1992;15(2):265-69.

\section{Mohan 1990}

Mohan V, Snehalatha C, Ramachandran A, Viswanathan M. Combination therapy of glibenclamide and insulin in NIDDM patients with secondary failure to oral drugs. [see comments]. Journal of the Association of Physicians of India 1990;38(8):537-41.

\section{Nathan 1988}

Nathan DM, Roussell A, Godine JE. Glyburide or insulin for metabolic control in non-insulin-dependent diabetes mellitus. A randomized, double-blind study. Annals of Internal Medicine 1988;108 (3):334-40.

\section{Niazi 1998}

Niazi R, Muzaffar Z. Comparison of bedtime NPH insulin or metformin combined with glibenclamide in secondary sulphonylurea failure in obese type II (NIDDM) patients. JPMA - Journal of the Pakistan Medical Association 1998;48(11):336-38.

\section{Niskanen 1992}

Niskanen L, Lahti J, Uusitupa M. Morning or bed-time insulin with or without glibenclamide in elderly type 2 diabetic patients unresponsive to oral antidiabetic agents. Diabetes Res Clin Pract 1992;18: 185-90.

\section{Okada 1996}

Okada S. The effect of an alpha-glucosidase inhibitor and insulin on glucose metabolism and lipid profiles in non-insulin-dependent diabetes mellitus. Journal of International Medical Research 1996;24 (5):438-47.

\section{Osei 1984}

Osei K, O’Dorisio TM, Falko JM. Concomitant insulin and sulfonylurea therapy in patients with type II diabetes. Effects on glucoregulation and lipid metabolism. American Journal of Medicine 1984;77 (6): 1002-09.

\section{Panahloo 1998}

Panahloo A, Mohamed Ali V, Andres C, Denver AE, Yudkin JS. Effect of insulin versus sulfonylurea therapy on cardiovascular risk factors and fibrinolysis in type II diabetes. Metabolism: Clinical o Experimental 1998;47(6):637-43.

\section{Pasmantier 1990}

Pasmantier R, Chaiken RL, Hirsch SR, Lebovitz HE. Metabolic effects of combination glipizide and human proinsulin treatment in NIDDM. Diabetes Care 1990;13 Suppl 3:42-46.

\section{Peacock 1984}

Peacock I, Tattersall RB. The difficult choice of treatment for poorly controlled maturity onset diabetes: tablets or insulin?. British Medical Journal Clinical Research Ed 1984;288(6435):1956-59.

\section{Polo 1998}

Polo V, Saibene A, Pontiroli AE. Nicotinamide improves insulin secretin and metabolic control in lean type 2 diabetic patients with secondary failure to sulphonylureas. Acta Diabetologica 1998;35(1): 61-64. 3679.

\section{Ponssen 2000}

Ponssen HH, Elte JW, Lehert P, Schouten JP, Bets D. Combined metformin and insulin therapy for patients with type 2 diabetes mellitus. Clinical Therapeutics 2000;22(6):709-18.

\section{Quatraro 1986}

Quatraro A, Consoli G, Ceriello A, Giugliano D. Combined insulin and sulfonylurea therapy in non-insulin-dependent diabetics with secondary failure to oral drugs: a one year follow-up. Diabete et Metabolisme 1986;12(6):315-18.

\section{Raskin 2001}

Raskin P, Rendell M, Riddle MC, Dole JF, Freed MI, Rosenstock J. A randomized trial of rosiglitazone therapy in patients with inadequately controlled insulin-treated type 2 diabetes. Diabetes Care 2001;24(7):1226-32.

\section{Reich 1987}

Reich A, Abraira C, Lawrence AM. Combined glyburide and insulin therapy in type II diabetes. Diabetes Research 1987;6(2):99-104. 


\section{Relimpio 1998}

Relimpio F, Pumar A, Losada F, Mangas MA, Acosta D, Astorga R. Adding metformin versus insulin dose increase in insulin-treated but poorly controlled Type 2 diabetes mellitus: an open-label randomized trial. Diabetic Medicine 1998;15(12):997-1002.

\section{Rivellese 2000}

Rivellese AA, Patti L, Romano G, Innelli F, Di Marino L, Annuzzi G, et al. Effect of insulin and sulfonylurea therapy, at the same level of blood glucose control, on low density lipoprotein subfractions in type 2 diabetic patients. Journal of Clinical Endocrinology \& Metabolism 2000;85(11):4188-92.

\section{Robinson 1998}

Robinson AC, Burke J, Robinson S, Johnston DG, Elkeles RS. The effects of metformin on glycemic control and serum lipids in insulintreated NIDDM patients with suboptimal metabolic control. Diabetes Care 1998;21(5):701-5. 3683.

\section{Rodier 1995}

Rodier M. Effects of insulin therapy upon plasma lipid fatty acids and platelet aggregation in NIDDM with secondary failure to oral antidiabetic agents. Diabetes Research and Clinical Practice 1995;28 (1):19-28.

\section{Romano 1997}

Romano G, Patti L, Innelli F, Di Marino L, Annuzzi G, Iavicoli M, et al. Insulin and sulfonylurea therapy in NIDDM patients. Are the effects on lipoprotein metabolism different even with similar blood glucose control?. Diabetes 1997;46:1601-6.

\section{Rosak 1985}

Rosak C, Schwarz O, Althoff PH, Schoffling K, Schmidt FH. [Combined treatment of type-2 diabetics with insulin and glibenclamide after secondary drug failure. Double-blind, insulin-placebo-controlled crossover study]. [German]. Deutsche Medizinische Wochenschrift 1985;110(51-52):1975-80.

\section{Samanta 1987}

Samanta A, Burden AC, Kinghorn HA. A comparative study of sulphonylurea and insulin therapy in non insulin dependent diabetics who had failed on diet therapy alone. Diabetes Research 1987;4: $183-5$.

\section{Sanchez 1999}

Sanchez-Barba Izquierdo MI, Ibarra Rueda JM, Ruiz de Adana PR. [The combination of insulin and metformin in obese patients with type-2 diabetes mellitus]. [Spanish]. Atencion Primaria 1999;24(8): 462-67.

Sane 1992

Sane T, Helve E, Yki-Järvinen H, Taskinen MR. One-year response to evening insulin therapy in non-insulin- dependent diabetes. Journal of Internal Medicine 1992;231:253-60. 4839.

\section{Sangiorgio 1996}

Sangiorgio L, Rabuazzo MA, Cordaro G, Grasso G, Condorelli L, Lunetta M. [Comparative study of the efficiency of ultralente insulin and NPH insulin combined with sulfonylurea in type 2 diabetes patients with secondary tolerance to sulfonylurea. Possible selection criteria]. Minerva Endocrinol 1996;21(2):47-52. 3681.

\section{Schade 1987}

Schade DS, Mitchell WJ, Griego G. Addition of sulfonylurea to insulin treatment in poorly controlled type II diabetes. A doubleblind, randomized clinical trial. JAMA 1987;257(18):2441-45.

\section{Schwartz 1997}

Schwartz SL, Fischer JS, Kipnes MS, Boyle M. Effects of short-term insulin therapy upon therapeutic response to glipizide. American Journal of Medicine 1987;83(3A):22-30.

\section{Schwartz 1998}

Schwartz S, Raskin P, Fonseca V, Graveline JF. Effect of troglitazone in insulin-treated patients with type II diabetes mellitus. Troglitazone and Exogenous Insulin Study Group. [see comments]. New England Journal of Medicine 1998;338(13):861-66.

\section{Simonson 1987}

Simonson DC, Delprato S, Castellino P, Groop L, DeFronzo RA. Effect of glyburide on glycemic control, insulin requirement, and glucose metabolism in insulin-treated diabetic patients. Diabetes 1987; 36(2):136-46.

\section{Simpson 1990}

Simpson HC, Sturley R, Stirling CA, Reckless JP. Combination of insulin with glipizide increases peripheral glucose disposal in secondary failure type 2 diabetic patients. Diabetic Medicine 1990;7(2): 143-47.

\section{Sinagra 1998}

Sinagra D, Scarpitta AM, Amato M. Effects of insulin-oral hypoglycemic agents combined therapy in outpatients with type 2 diabetes. European Review for Medical \& Pharmacological Sciences 1998; 2(5-6): 175-79.

\section{Soneru 1993}

Soneru IL, Agrawal L, Murphy JC, Lawrence AM, Abraira C. Comparison of morning or bedtime insulin with and without glyburide in secondary sulfonylurea failure. Diabetes Care 1993;16(6):896-901.

\section{Sotaniemi 1990}

Sotaniemi EA, Vierimaa E, Huupponen R, Karvonen I, Vuoti MJ, Rytomaa K. Insulin and sulphonylurea in the therapy of type 2 diabetes. Diabetes Research and Clinical practice 1990;8:243-51.

\section{Standl 1999}

Standl E, Baumgartl HJ, Fuchtenbusch M, Stemplinger J. Effect of acarbose on additional insulin therapy in type 2 diabetic patients with late failure of sulphonylurea therapy. Diabetes Obesity \& Metabolism 1999;1(4):215-20.

\section{Stenman 1988}

Stenman S, Groop PH, Saloranta C, Totterman KJ, Fyhrqvist F, Groop L. Effects of the combination of insulin and glibenclamide in type 2 (non-insulin-dependent) diabetic patients with secondary failure to oral hypoglycaemic agents. Diabetologia 1988;31(4):20613.

\section{Stocks 1988}

Stocks AE MAH. Lack of effect of glibenclamide on insulin requirements and diabetic control in persons with insulin-dependent diabetes. Medical Journal of Australia 1988;149(9):472-73.

\section{Stradner 1990}

Stradner F, Pieber T, Toplak H, Schreiber U, Pfeiffer KP. [Insulin-sulfonylurea combination therapy in secondary therapy failure with sulfonylurea compounds. Randomized study between evening and morning intermediary insulin administration using the Novo Pen semi- automatic insulin injector]. Schweizerische medizinische Wochenschrift 1990;120(27-28):989-94. 4250. 


\section{Thompson 1998}

Thompson RG, Pearson L, Schoenfeld SL, Kolterman OG. Pramlintide, a synthetic analog of human amylin, improves the metabolic profile of patients with type 2 diabetes using insulin. The Pramlintide in Type 2 Diabetes Group. Diabetes Care 1998;21(6):987-93.

Tovi 1998

Tovi J, Ingemansson SO, Engfeldt P. Insulin treatment of elderly type 2 diabetic patients: effects on retinopathy. Diabetes \& Metabolism 1998;24(5):442-47.

\section{Trischitta 1992}

Trischitta V, Italia S, Mazzarino S, Buscema M, Rabuazzo AM, Sangiorgio, $\mathrm{L}$, et al. Comparison of combined therapies in treatment of secondary failure to glyburide. Diabetes Care 1992;15(4):539-42.

\section{Trischitta 1998}

Trischitta V, Italia S, Raimondo M, Guardabasso V, Licciardello C, Runello F, et al. Efficacy of combined treatments in NIDDM patients with secondary failure to sulphonylureas. Is it predictable?. Journal of Endocrinological Investigation 1998;21(11):744-47.

\section{Trznadel 1997}

Trznadel-Morawska I, Malecki M, Sieradzki J. [Estimation of different models of insulin therapy in noninsulin-dependent diabetes mellitus]. Przeglad lekarski 1997;54(5):308-13. 3680.

Turner 1999 (2)

Turner RC, Cull CA, Frighi V, Holman RR. Glycemic control with diet, sulfonylurea, metformin, or insulin in patients with type 2 diabetes mellitus: progressive requirement for multiple therapies (UKPDS 49). UK Prospective Diabetes Study (UKPDS) Group. JAMA 1999;281(21):2005-12.

\section{UKPDS 131995}

United Kingdom Prospective Diabetes Study (UKPDS). 13: Relative efficacy of randomly allocated diet, sulphonylurea, insulin, or metformin in patients with newly diagnosed non-insulin dependent diabetes followed for three years. [see comments]. BMJ 1995;310 (6972):83-88

\section{UKPDS 241998}

United Kingdom Prospective Diabetes Study 24: a 6-year, randomized, controlled trial comparing sulfonylurea, insulin, and metformin therapy in patients with newly diagnosed type 2 diabetes that could not be controlled with diet therapy. United Kingdom Prospective Diabetes Study Group. [see comments]. Annals of Internal Medicine 1998;128(3): 165-75.

\section{UKPDS 331998}

Intensive blood-glucose control with sulphonylureas or insulin compared with conventional treatment and risk of complications in patients with type 2 diabetes (UKPDS 33). UK Prospective Diabetes Study (UKPDS) Group. [see comments]. [erratum appears in Lancet 1999 Aug 14;354(9178):602]. Lancet 1998;352(9131):837-53.

\section{Vigneri 1991}

Vigneri R, Trischitta V, Italia S, Mazzarino S, Rabuazzo MA, Squatrito, S. Treatment of NIDDM patients with secondary failure to glyburide: comparison of the addition of either metformin or bedtime NPH insulin to glyburide. Diabete et Metabolisme 1991;17(1 Pt 2):232-34.

\section{Wolffenbuttel 1989}

Wolffenbuttel BH, Weber RF, van Koetsveld PM, Weeks L, Verschoor L. A randomized crossover study of sulphonylurea and insulin treatment in patients with type 2 diabetes poorly controlled on dietary therapy. Diabetic Medicine 1989;6:520-25.

\section{Yki-Jarvinen 2000}

Yki-Jarvinen H, Dressler A, Ziemen M, HOE 901/300s Study, Group. Less nocturnal hypoglycemia and better post-dinner glucose control with bedtime insulin glargine compared with bedtime NPH insulin during insulin combination therapy in type 2 diabetes. $\mathrm{HOE}$ 901/3002 Study Group. Diabetes Care 2000;23(8):1130-36.

\section{Yu 1999}

Yu JG, Kruszynska YT, Mulford MI, Olefsky JM. A comparison of troglitazone and metformin on insulin requirements in euglycemic intensively insulin-treated type 2 diabetic patients. Diabetes 1999;48 (12):2414-21

\section{Yudkin 2000}

Yudkin JS, Panahloo A, Stehouwer C, Emeis JJ, Bulmer K, Mohamed-Ali V, Denver AE. The influence of improved glycaemic control with insulin and sulphonylureas on acute phase and endothelial markers in Type II diabetic subjects. Diabetologia 2000;43(9):10991106.

\section{References to studies awaiting assessment}

\section{Goudswaard 2004}

Goudswaard AN, Stolk RP, Zuithoff P, de Valk HW, Rutten GE Starting insulin in type 2 diabetes: Continue oral hypoglycemic agents? A randomized trial in primary care. Journal of Family Practice 2004;53(5):393-399.

\section{Olsson 2002}

Olsson PO, Lindstrom T. Combination-therapy with bedtime nph insulin and sulphonylureas gives similar glycaemic control but lower weight gain than insulin twice daily in patients with type 2 diabetes. Diabetes Metab 2002;28(4 Pt 1):272-277.

Stehouwer 2003

* Stehouwer MH, DeVries JH, Lumeij JA, Ader HJ, Engbers AM, Iperen AA, Snoek FJ, Heine RJ. Combined bedtime insulin-daytime sulphonylurea regimen compared with two different daily insulin regimens in type 2 diabetes: effects on HbAlc and hypoglycaemia rate-a randomised trial. Diabetes Metab Res Rev 2003;19(2):148-152.

\section{Additional references}

ADA 1997

American Diabetic Association. Report of the Expert Committee on the Diagnosis and Classification of Diabetes Mellitus. Diabetes Care 1997;20:1183-97.

ADA 1999

The Expert Committee on the Diagnosis and Classification of Diabetes Mellitus. Report of The Expert Committee on the Diagnosis and Classification of Diabetes Mellitus. Diabetes Care 1999;22(Suppl 1):S5-19

\section{Agurs 1997}

Agurs Collins TD, Kumanyika SK, Ten Have TR, Adams Campbell LL. A randomized controlled tria of weight reduction and exercise for diabetes management in older African-American subjects. Diabetes Care 1997;20(10):1503-11.

\section{Armitage 2002}

Armitage P, Berry G, Matthews JNS. Statistical methods in medical research, par. 5.3. 4th Edition. Blackwell Science, 2002:paragraph 5.3 


\section{Bosello 1997}

Bosello O, Armellini F, Zamboni M, Fitchet M. The benefits of modest weight loss in type II diabetes. International Journal of Obesity and related Metabolic disorders 1997;21 Suppl 1:S10-3.

\section{Burgers 2002}

Burgers JS, Bailey JV, Klazinga NS, van der Bij AK, Grol R, Feder G. Inside guidelines: comparative analysis of recommendations and evidence in diabetes guidelines from 13 countries. Diabetes Care 2002; 25(11):1933-39.

\section{Cohen 1960}

Cohen J. A coefficient of agreement for nominal scales. Educational and psychological measurement 1960;20:37-46.

\section{DCCT 1993}

The effect of intensive treatment of diabetes on the development and progression of long-term complications in insulin-dependent diabetes mellitus. The Diabetes Control and Complications Trial Research Group. The New England journal of medicine 1993;329: $977-86$.

\section{de Sonnaville 1998}

Sonnaville de JJ, Snoek FJ, Colly LP, Deville W, Wijkel D, Heine $\mathrm{RJ}$. Well-being and symptoms in relation to insulin therapy in type 2 diabetes. Diabetes Care 1998;21(6):919-24.

\section{DerSimonian 1986}

DerSimonian R, Laird N. Meta-analysis in clinical trials. Controlled clinical trials 1986;7(3):177-88. 28.

\section{Egger 1997}

Egger M, Davey SG, Schneider M, Minder C. Bias in meta-analysis detected by a simple, graphical test. BMJ 1997;315(7109):629-34.

\section{Garber 2003}

Garber AJ. Benefits of combination therapy of insulin and oral hypoglycemic agents. Archives of internal medicine 2003;163(15):178182.

\section{Goddijn 1999}

Goddijn PP, Bilo HJ, Feskens EJ, Groenier KH, van der Zee KI, Meyboom-de Jong B. Longitudinal study on glycaemic control and quality of life in patients with Type 2 diabetes mellitus referred for intensified control. Diabetic Medicine 1999;16(1):23-30.

\section{Higgins 2003}

Higgins JP, Thompson SG, Deeks JJ, Altman DG. Measuring inconsistency in meta-analyses. BMJ 2003;327(7414):557-60.

\section{Jadad 1996}

Jadad AR, Moore RA, Carroll D, Jenkinson C, Reynolds DJ, Gavaghan DJ, et al. Assessing the quality of reports of randomized clinical trials: Is blinding necessary?. Controlled Clinical Trials 1996;17: $1-12$.

\section{Johnson 1996}

Johnson JL, Wolf SL, Kabadi UM. Efficacy of insulin and sulfonylurea combination therapy in type II diabetes. A meta-analysis of the randomized placebo-controlled trials. Archives of internal medicine 1996;156(3):259-64.

\section{Lau 1997}

Lau J, Loannidis JPA, Schmid CH. Quantitative synthesis in systematic reviews. Annals of internal medicine 1997;127:820-6.

\section{Little 1986}

Little RR, England JD, Wiedmeyer HM, McKenzie EM, Mitra R, Erhart PM, Durham JB, Goldstein DE. Interlaboratory standardization of glycated hemoglobin determinations. Clinical chemistry 1986; 32(2):358-60.

\section{Mulrow 1997}

Mulrow CD, Oxman AD. Cochrane Collaboration Handbook. updated September 1997. Vol. 4, Oxford: Update Software, 1997.

\section{NDDG 1979}

National Diabetes Data Group. Classification and diagnosis of diabetes mellitus and other categories of glucose intolerance. Diabetes 1979;28:1039-57.

\section{Peters 1991}

Peters AL, Davidson MB. Insulin plus a sulfonylurea agent for treating type 2 diabetes. Annals of internal medicine 1991;115(1):45-53.

\section{Pugh 1992}

Pugh-JA, Wagner-ML, Sawyer-J, Ramirez-G, Tuley-M, Friedberg-SJ. Is combination sulfonylurea and insulin therapy useful in NIDDM patients? A metaanalysis [see comments]. Diabetes Care 1992;15: 953-9.

\section{Riddle 2002}

Riddle MC. Timely addition of insulin to oral therapy for type 2 diabetes. Diabetes Care 2002;25(2):395-96.

Riddle 2003

Riddle MC, Rosenstock J, Gerich J. The treat-to-target trial: randomized addition of glargine or human NPH insulin to oral therapy of type 2 diabetic patients. Diabetes Care 2003;26(11):3080-86.

\section{Rosenthal 1994}

Rosenthal R. Parametric measures of effect size. In: CooperH, HedgesHV editor(s). The handbook of research synthesis. New York: Sage Foundation, 1994:231-44.

Ruige 1998

Ruige JB, Assendelft WJ, Dekker JM, Kostense PJ, Heine RJ, Bouter LM. Insulin and risk of cardiovascular disease: a meta-analysis. Circulation 1998;97(10):996-1001.

Schulz 1995

Schulz KF, Chalmers I, Hayes RJ, Altman DG. Empirical evidence of bias: dimensions of methodological quality associated with estimates of treatment effects in controlled trials. Journal of the American Medical Association 1995;273:408-12.

\section{Stout 1990}

Stout RW. Insulin and atheroma. 20-yr perspective. Diabetes Care 1990;13(6):631-54.

\section{Turner 1999}

Turner RC, Cull CA, Frighi V, Holman RR. Glycemic control with diet, sulfonylurea, metformin, or insulin in patients with type 2 diabetes mellitus: progressive requirement for multiple therapies (UKPDS 49). UK Prospective Diabetes Study (UKPDS) Group. JAMA 1999;281(21):2005-12.

\section{UKPDS 33}

Intensive blood-glucose control with sulphonylureas or insulin compared with conventional treatment and risk of complications in patients with type 2 diabetes (UKPDS 33). UK Prospective Diabetes Study (UKPDS) Group. Lancet 1998;352:837-53. 
van der Does 1996

Does van der FE, De Neeling JN, Snoek FJ, Kostense PJ, Grootenhuis PA, Bouter LM, Heine RJ. Symptoms and well-being in relation to glycemic control in type II diabetes. Diabetes Care 1996;19(3):20410 .

\section{Van Tulder 1997}

Van Tulder MW, Assendelft WJJ, Koes BW, Bouter LM. Method guidelines for systematic reviews in the Cochrane Collaboration Back Review Group for Spinal Disorders. Spine 1997;22:2323-30.

\section{Westphal 2003}

Westphal SA, Palumbo PJ. Insulin and oral hypoglycemic agents should not be used in combination in the treatment of type 2 diabetes. Archives of internal medicine 2003;163(15):1783-85.

\section{WHO 1980}

WHO Expert Committee on Diabetes Mellitus. Second report. Technical Report Series 646. 1980.

\section{WHO 1985}

World Health Organisation. Diabetes Mellitus: Report of a WHO Study Group. Technical Report Series No. 727. 1985.

\section{WHO 1999}

World Health Organization. Definition, Diagnosis and Classification of Diabetes Mellitus and its Complications. Report of a WHO Consultation. Part 1: Diagnosis and Classification of Diabetes Mellitus. Geneva: World Health Organization, 1999:1-59.

\section{Yki-Järvinen 2000}

Yki-Järvinen H, Dressler A, Ziemen M. Less nocturnal hypoglycemia and better post-dinner glucose control with bedtime insulin glargine compared with bedtime NPH insulin during insulin combination therapy in type 2 diabetes. HOE 901/3002 Study Group. Diabetes Care 2000;23(8):1130-36.

\section{Yki-Järvinen 2001}

Yki-Järvinen $\mathrm{H}$. Combination therapies with insulin in type 2 diabetes. Diabetes Care 2001;24(4):758-67.

\section{Zavaroni 1989}

Zavaroni I, Bonora E, Pagliara M, Dall'Aglio E, Luchetti L, Buonanno $G$, et al. Risk factors for coronary artery disease in healthy persons with hyperinsulinemia and normal glucose tolerance. The New England Journal of Medicine 1989;320(11):702-6.

* Indicates the major publication for the study

TAB LES

\section{Characteristics of included studies}

\begin{tabular}{|c|c|}
\hline Study & Bachmann 1988 \\
\hline Methods & $\begin{array}{l}\text { Design: randomised placebo controlled trial } \\
\text { Duration: } 6 \text { months } \\
\text { Randomisation procedure: unclear } \\
\text { Blinding: patients yes; care provider yes; outcome assessor unclear } \\
\text { Intention to treat: no }\end{array}$ \\
\hline Participants & $\begin{array}{l}\text { Country: Germany } \\
\text { Setting: secondary care outpatient } \\
\text { Inclusion criteria: > } 40 \text { years; }>3 \text { year SU therapy; > } 3 \text { months max. SU therapy; FBG > } 12.2 \mathrm{mmol} / \mathrm{l} \text { or } \\
\text { post-prandial BG > } 15.5 \mathrm{mmol} / \mathrm{l} \text {; bodyweight }<150 \% \text { of 'ideal bodyweight' } \\
\text { Exclusion criteria: unclear } \\
\text { Patients randomised: } 140 \\
\text { Nr of patients/group: unclear } \\
\text { Drop-outs / loss to follow-up: } 72 \\
\text { Nr of patients/group analysed: } 37 \text { / } 31 \\
\text { Age (years, median): } 66 \text { / } 69 \\
\text { Sex (\% male): } 38 \text { / } 19 \\
\text { Diabetes duration (years, median): } 10 / 12 \\
\text { Diabetes therapy: glibenclamide } 15 \mathrm{mg}\end{array}$ \\
\hline Interventions & $\begin{array}{l}\text { Group 1: mixed insulin }(25 \% \text { regular } / 75 \% \text { protamine insulin })+\text { glibenclamide } 15 \mathrm{mg} \\
\text { Group 2: mixed insulin }(25 \% \text { regular } / 75 \% \text { protamine insulin })+\text { placebo } \\
\text { Glucose targets to which insulin doses were titrated: } \mathrm{FBG}<=10 \mathrm{mmol} / \mathrm{l} \text { and post-prandial BG } £ 12.2 \mathrm{mmol} / \mathrm{l}\end{array}$ \\
\hline Outcomes & Glycaemia: FBG, post-prandial BG, HbA1 \\
\hline
\end{tabular}




\section{Characteristics of included studies (Continued)}

\begin{tabular}{|c|c|}
\hline & $\begin{array}{l}\text { Weight: Weight } \\
\text { Insulin amount (E): mean daily insulin dose at final visit } \\
\text { Hypoglycaemia: hypoglycaemic episodes } \\
\text { Well-being: not reported } \\
\text { Treatment Satisfaction: not reported } \\
\text { Adverse events: not reported }\end{array}$ \\
\hline Notes & $\begin{array}{l}\text { Quality score: } 2 \\
\text { Characteristics only available for analysed patients; presented as median values } \\
\text { Sponsoring: not specified }\end{array}$ \\
\hline Allocation concealment & $\mathrm{B}$ \\
\hline Study & Bastyr 1999 \\
\hline Methods & $\begin{array}{l}\text { Design: randomised controlled trial } \\
\text { Duration: } 2 \text { months } \\
\text { Randomisation procedure: computer generated } \\
\text { Blinding: patients no; care provider no; outcome assessor no } \\
\text { Intention to treat: yes }\end{array}$ \\
\hline Participants & $\begin{array}{l}\text { Country: USA, Europe } \\
\text { Setting: secondary care outpatient, } 58 \text { centers, } 11 \text { countries } \\
\text { Inclusion criteria: } 40-85 \text { year; type } 2 \text { diabetes according to WHO; secondary failure on SU; FBG > } 7.8 \\
\text { mmol/l or AMBG > } 10.0 \text { mmol/l or HbA1c > } 150 \% \text { of the upper limit of the non-diabetic range at the local } \\
\text { laboratory } \\
\text { Exclusion criteria: unclear } \\
\text { Patients randomised: } 423 \mathrm{Nr} \text { of patients/group: } 139 / 149 / 135 \\
\text { Drop-outs / loss to follow-up: } 27 \\
\text { Nr of patients/group analysed: } 139 / 149 \text { / } 135 \\
\text { Age (years, median): } 60.1 / 59.6 / 60.7 \\
\text { Sex (\% male): } 44 \text { / } 58 \text { / } 54 \\
\text { Diabetes duration (years): } 10 / 9 / 9 \\
\text { Diabetes therapy: unclear }\end{array}$ \\
\hline Interventions & $\begin{array}{l}\text { Group 1: pre-prandial insulin Lispro + glibenclamide } 15 \mathrm{mg} \text { (Europe) or glyburide } 20 \mathrm{mg} \text { (USA) } \\
\text { Group 2: pre-prandial insulin Lispro + bedtime NPH insuline } \\
\text { Group 3: bedtime NPH insulin + glibenclamide } 15 \mathrm{mg} \text { (Europe) or } 20 \mathrm{mg} \text { (USA) } \\
\text { Glucose targets to which insulin doses were titrated: not available }\end{array}$ \\
\hline$\overline{\text { Outcomes }}$ & $\begin{array}{l}\text { Glycaemia: FBG, post-prandial BG, HbA1c } \\
\text { Weight: body weight, BMI } \\
\text { Insulin amount (E): mean daily insulin dose at final visit } \\
\text { Hypoglycaemia: hypoglycaemic episodes, } \\
\text { Well-being: not reported } \\
\text { Treatment Satisfaction: not reported } \\
\text { Adverse events: reported }\end{array}$ \\
\hline Notes & $\begin{array}{l}\text { Quality score: } 3 \\
\text { Sponsoring: pharmaceutical }\end{array}$ \\
\hline Allocation concealment & $\mathrm{C}$ \\
\hline Study & Chow 1995 \\
\hline Methods & $\begin{array}{l}\text { Design: randomised controlled trial } \\
\text { Duration: } 8 \text { months } \\
\text { Randomisation procedure: "consecutively and alternately" }\end{array}$ \\
\hline
\end{tabular}

Insulin monotherapy versus combinations of insulin with oral hypoglycaemic agents in patients with type 2 diabetes mellitus (Review) 


\section{Characteristics of included studies (Continued)}

\begin{tabular}{|c|c|}
\hline & $\begin{array}{l}\text { Blinding: patients no ; care provider no ; outcome assessor no } \\
\text { Intention to treat: no }\end{array}$ \\
\hline Participants & $\begin{array}{l}\text { Country: Hong Kong } \\
\text { Setting: secondary care outpatients } \\
\text { Inclusion criteria: age > } 20 \text { year and maximum dose of SU and/or metformin and FPG > } 7.8 \text { mmol/1 } \\
\text { Exclusion criteria: MI, CCF, PVD, renal failure, hepatic disease, proliferative retinopathy, severe maculopathy, } \\
\text { insulin-dependent diabetes, previous treatment with insulin, excessive alcohol consumption, night-shift work. } \\
\text { Patients randomised: } 55 \\
\text { Nr of patients/group: } 28 \text { / } 27 \\
\text { Drop-outs / loss to follow-up: } 1 / 1 \\
\text { Nr of patients/group analysed: } 27 \text { / } 26 \\
\text { Age (years): } 57 \text { / } 51 \\
\text { Sex (\% male): } 33 \text { / } 35 \\
\text { Diabetes duration (years): } 9.9 \text { / } 8.0 \\
\text { Diabetes therapy: SU (10), SU+metformin (17) / SU (9), SU+metformin (17) }\end{array}$ \\
\hline Interventions & $\begin{array}{l}\text { Group 1: OHA continued + intermediate-acting insulin (NPH) before bedtime } \\
\text { Group 2: intermediate-acting insulin (NPH) before breakfast (a dinner injection was added when }>24 \mathrm{U} \\
\text { were needed) (1 patient received NPH/regular insulin 70/30) } \\
\text { Glucose targets to which insulin doses were titrated: FPG }<7.8 \mathrm{mmol} / \mathrm{l} \text { (both groups) and post-prandial PG } \\
<11.1 \mathrm{mmol} / \mathrm{l} \text { (group 2) }\end{array}$ \\
\hline Outcomes & $\begin{array}{l}\text { Glycaemia: FPG, HbA1c } \\
\text { Weight: body weight, BMI } \\
\text { Insulin amount (E): insulin doses at } 6 \text { months } \\
\text { Hypoglycaemia: hypoglycaemia } \\
\text { Well-being: well-being questionnaire } \\
\text { Treatment Satisfaction: injection pain and problems questionnaire } \\
\text { Adverse events: not reported }\end{array}$ \\
\hline Notes & $\begin{array}{l}\text { Quality score: } 1 \\
\text { Sponsoring: pharmaceutical }\end{array}$ \\
\hline
\end{tabular}

Study

Fövényi 1997

Methods

Design: Randomised controlled trial

Duration: 3 years

Randomisation procedure: unclear

Blinding: patients no; care provider no; outcome assessor no

Intention to treat: no

Participants Country: Hungary

Setting: Secondary care outpatient, single centre

Inclusion criteria: $\mathrm{HbA1c}>7.5 \%$ (normal range not given, HPLC assay) despite max. Sulphonylurea therapy ( \pm acarbose, \pm biguanide)

Exclusion criteria: unclear

Patients randomised: 286

Nr of patients/group: $141 / 145$

Drop-outs / loss to follow-up: 82 (58.2\%) subjects from group 1 switched to twice daily conventional insulin treatment because of insufficient glycaemic control

$\mathrm{Nr}$ of patients/group analysed: $141 / 145$

Age (years, mean): 59.8 yrs / 60.5 yrs

Sex (\% male): $41.8 \% / 40.7 \%$

Diabetes duration (years): $10.2 / 10.5$

Insulin monotherapy versus combinations of insulin with oral hypoglycaemic agents in patients with type 2 diabetes mellitus (Review) 


\section{Characteristics of included studies (Continued)}

Diabetes therapy: Glibenclamide 96\%, Gliclazide 4\%

\begin{tabular}{ll}
\hline Interventions & Group 1: Sulphonylurea (dose unchanged) + bedtime NPH insulin (6-10 units initially) \\
Group 2: Twice daily conventional insulin (not specified) \\
Glucose targets to which insulin doses were titrated: Fasting blood glucose $<7.0 \mathrm{mmol} / 1$ \\
Pre-prandial / bedtime $<10.0 \mathrm{mmol} / \mathrm{l}$ \\
Max dose of bedtime NPH allowed $=40 \mathrm{units}$, above this converted to twice daily insulin. \\
If FBG $<7.0 \mathrm{mmol} / \mathrm{l}$, but daytime $>10.0 \mathrm{mmol} / \mathrm{l}$, NPH changed to long-acting insulin (Humulin U or \\
Ultratard). \\
Max dose of long acting insulin allowed = 28 units, above this converted to twice daily insulin. \\
\hline Glycaemia: HbA1c (method and normal range not given) \\
Weight: Weight gain \\
Insulin amount (E): Mean daily insulin dose at final visit \\
Hypoglycaemia: not reported \\
Well-being: not reported \\
Treatment Satisfaction: not reported \\
Adverse events: not reported \\
Quality score: 1 (drop-outs described) \\
Sponsoring: not stated \\
No predetermined time for end-point analyses. Patients randomised to one or other treatment and analysed \\
3.5 years after recruitment commenced. Duration of follow-up therefore variable (expressed as mean \pm SD). \\
Analysis not intention to treat. Large drop-out of subjects from combination therapy group. Subjects analysed \\
as 3 separate groups. 1. SU/insulin. 2. Twice daily insulin. 3. Converted from SU/insulin to twice daily \\
insulin.
\end{tabular}

\section{Study}

\section{Gutniak 1987}

Methods

Design: double-blind placebo controlled trial

Duration: 101/2 months

Randomisation procedure: unclear

Blinding: patients yes; care provider yes; outcome assessor unclear

Intention to treat: unclear

Participants Country: Sweden

Setting: secondary care outpatient

Inclusion criteria: pre-prandial BG > $11 \mathrm{mmol} / \mathrm{l}$ in $50 \%$ of the samples during 1 months unless diet, exercise, and $28 \mathrm{mg}$ glyburide

Exclusion criteria: unclear

Patients randomised: 20

$\mathrm{Nr}$ of patients/group: $10 / 10$

Drop-outs / loss to follow-up: 0

$\mathrm{Nr}$ of patients/group analysed: $10 / 10$

Age (years): 57

Sex (\% male): unclear

Diabetes duration (years): 14.1

Diabetes therapy: glyburide $20 \mathrm{mg} /$ day

Interventions

Group 1: mixed insulin (intermediate-acting (NPH) plus regular insulin) twice daily + glyburide 10,5 mg Group 2: mixed insulin (intermediate-acting $(\mathrm{NPH})$ plus regular insulin twice daily + placebo tablets Glucose targets to which insulin doses were titrated: $\mathrm{FBG}<8 \mathrm{mmol} / \mathrm{l}$ and post-prandial $\mathrm{BG}<10 \mathrm{mmol} / \mathrm{l}$

Outcomes

Glucose profile: FBG, HbA1c

Other: body weight, insulin amount

Adverse effects: hypoglycaemia 


\section{Characteristics of included studies (Continued)}

Notes

Quality score: 2

Sponsoring: pharmaceutical

$\mathrm{SD}$ calculated from SE; data in text don't correspond with graphs

Allocation concealment $\mathrm{B}$

\begin{tabular}{|c|c|}
\hline Study & Holman 1987 \\
\hline Methods & $\begin{array}{l}\text { Design: cross-over study } \\
\text { Duration: } 5 \text { × } 8 \text { weeks } \\
\text { Randomisation procedure: unclear } \\
\text { Blinding: patients no; care provider no; outcome assessor no } \\
\text { Intention to treat: no }\end{array}$ \\
\hline Participants & $\begin{array}{l}\text { Country: United Kingdom } \\
\text { Setting: primary care } \\
\text { Inclusion criteria: maximal SU therapy, asymptomatic diabetes type } 2 \\
\text { Exclusion criteria: retinopathy, cardiovascular disease } \\
\text { Patients randomised: } 17 \\
\text { Drop-outs / loss to follow-up: } 2 \\
\text { Nr of patients analysed: } 15 \\
\text { Age (years): } 57 \\
\text { Sex (\% male): } 50 \\
\text { Diabetes duration (years): } 8 \\
\text { Diabetes therapy: 'maximal SU therapy' }\end{array}$ \\
\hline Interventions & $\begin{array}{l}\text { Group 1: maximal SU } \\
\text { Group 2: maximal SU + metformin } \\
\text { Group 3: maximal SU + long-acting insulin once daily } \\
\text { Group 4: long-acting insulin once daily } \\
\text { Group 5: long-acting insulin once daily + short-acting insulin twice daily } \\
\text { Glucose targets to which insulin doses were titrated: FPG }<6 \mathrm{mmol} / \mathrm{l}\end{array}$ \\
\hline Outcomes & $\begin{array}{l}\text { Glycaemia: basal PG, HbA1 } \\
\text { Weight: body weight } \\
\text { Insulin amount (E): insulin amount } \\
\text { Hypoglycaemia: hypoglycaemia reported } \\
\text { Well-being: not reported } \\
\text { Treatment Satisfaction: not reported } \\
\text { Adverse events: not reported }\end{array}$ \\
\hline Notes & $\begin{array}{l}\text { Quality score: } 1 \\
\text { Sponsoring: unclear }\end{array}$ \\
\hline
\end{tabular}

\section{Study}

Karlander 1991

Methods see Gutniak 1987

Participants

Interventions

Outcomes

Notes

Allocation concealment $\mathrm{D}$

Study

\section{Lotz 1988}

Methods Design: randomised controlled trial

Insulin monotherapy versus combinations of insulin with oral hypoglycaemic agents in patients with type 2 diabetes mellitus (Review)

Copyright @ 2006 The Cochrane Collaboration. Published by John Wiley \& Sons, Ltd 


\section{Characteristics of included studies (Continued)}

\begin{tabular}{|c|c|}
\hline & $\begin{array}{l}\text { Duration: } 2 \text { year } \\
\text { Randomisation procedure: 'randomised order' (=alternately?) } \\
\text { Blinding: patients no ; care provider no ; outcome assessor no } \\
\text { Intention to treat: yes }\end{array}$ \\
\hline Participants & $\begin{array}{l}\text { Country: Germany } \\
\text { Setting: secondary care outpatient } \\
\text { Inclusion criteria: age } 45-80 \text {; maximal OHAs > } 2 \text { year; FBG }>11.1 \mathrm{mmol} / \mathrm{l} \text {; post-prandial BG }>13.9 \mathrm{mmol} / \mathrm{l} \text {; } \\
\mathrm{HbA} 1 \text { > } 11.0 \% \text {; weight }<130 \% \text { BROCA }(\text { length }(\mathrm{cm}) \text { - weight }(\mathrm{kg})) \\
\text { Exclusion criteria: unclear } \\
\text { Patients randomised: } 16 \\
\mathrm{Nr} \text { of patients/group: } 8 \text { / } 8 \\
\text { Drop-outs / loss to follow-up: } 0 \text { / } 0 \\
\mathrm{Nr} \text { of patients/group analysed: } 8 \text { / } 8 \\
\text { Age (years): } 65 \text { / } 59 \\
\text { Sex (\% male): unclear } \\
\text { Diabetes duration (years): } 15 / 11 \\
\text { Diabetes therapy: SU (not specified) }\end{array}$ \\
\hline Interventions & $\begin{array}{l}\text { Group 1: insulin (not specified), twice daily } \\
\text { Group 2: intermediate-insulin once a day + glibenclamide } 7 \mathrm{mg} \\
\text { Glucose targets to which insulin doses were titrated: unclear }\end{array}$ \\
\hline Outcomes & $\begin{array}{l}\text { Glycaemia: FBG, HbA1 (Biorad) } \\
\text { Weight: weight (\% BROCA) } \\
\text { Insulin amount (E): daily insulin dose at final visit } \\
\text { Hypoglycaemia: qualitatively reported } \\
\text { Well-being: not reported } \\
\text { Treatment Satisfaction: not reported } \\
\text { Adverse events: not reported }\end{array}$ \\
\hline Notes & $\begin{array}{l}\text { Quality score: } 1 \\
\text { Sponsoring: not reported }\end{array}$ \\
\hline & C \\
\hline
\end{tabular}

\begin{tabular}{|c|c|}
\hline Study & Lundershausen 1987 \\
\hline Methods & $\begin{array}{l}\text { Design: randomised controlled trial } \\
\text { Duration: } 6 \text { months } \\
\text { Randomisation procedure: not reported } \\
\text { Blinding: patients yes; care provider yes; outcome assessor unclear } \\
\text { Intention to treat: yes }\end{array}$ \\
\hline Participants & $\begin{array}{l}\text { Country: Germany } \\
\text { Setting: unclear } \\
\text { Inclusion criteria: maximal SU (glibenclamide } 15 \mathrm{mg} \text { ) and FBG }>10 \mathrm{mmol} / \mathrm{l} \text {, } \\
\text { Exclusion criteria: infections, kidney failure, liver disease, neoplasia, other metabolic disorders, co-medication } \\
\text { interfering with glucose metabolism } \\
\text { Patients randomised: } 79 \\
\mathrm{Nr} \text { of patients/group: } 39 \text { / } 40 \\
\text { Drop-outs / loss to follow-up: } 0 \text { / } 0 \\
\mathrm{Nr} \text { of patients/group analysed: } 39 \text { / } 40 \\
\text { Age (years): } 62 \text { / } 62 \\
\text { Sex (\% male): } 38 \text { / } 33 \\
\text { Diabetes duration (years): } 11 / 11 \\
\text { Diabetes therapy: glibenclamide } 15 \mathrm{mg}\end{array}$ \\
\hline
\end{tabular}

Insulin monotherapy versus combinations of insulin with oral hypoglycaemic agents in patients with type 2 diabetes mellitus (Review) 27 


\section{Characteristics of included studies (Continued)}

Interventions

Group 1: insulin + glibenclamide $10 \mathrm{mg}$

Group 2: insulin + placebo

Glucose targets to which insulin doses were titrated: mean glucose value $12 \mathrm{mmol} / \mathrm{l}$

\begin{tabular}{ll}
\hline Outcomes & Glycaemia: "glucose value according to Michaelis" (normal values good: $<11$ mmol/l; acceptable $>11<16.5$ \\
& mmol/l; poor $>16.5 \mathrm{mmol} / \mathrm{l})$ \\
& Weight: weight change; BMI change (only reported for all patients) \\
& Insulin amount: daily insulin dose \\
& Hypoglycaemia: qualitatively reported \\
& Well-being: not reported \\
& Treatment Satisfaction: not reported \\
& Adverse events: not reported \\
\hline Notes & Quality score: 3 \\
& $\begin{array}{l}\text { Sponsoring: not reported } \\
\text { Type of insulin not specified } \\
\text { One year follow-up study, however at six months } 41 \text { patients discontinued oral medication }\end{array}$ \\
\hline Allocation concealment & B \\
\hline Study & Mäkimattila 1999 \\
\hline Methods & see Yki-Järvinen 1999 \\
\hline Participants & \\
\hline Interventions & \\
\hline Outcomes & B \\
\hline Allocation concealment & \\
\hline
\end{tabular}

\begin{tabular}{|c|c|}
\hline Study & Pontiroli 1990 \\
\hline$\overline{\text { Methods }}$ & $\begin{array}{l}\text { Design: Randomised cross-over controlled trial } \\
\text { Duration: } 2 \mathrm{x} 3 \text { month treatment periods } \\
\text { Randomisation procedure: unclear } \\
\text { Blinding: patients no; care provider no; outcome assessor unclear } \\
\text { Intention to treat: no }\end{array}$ \\
\hline Participants & $\begin{array}{l}\text { Country: Italy } \\
\text { Setting: not stated } \\
\text { Inclusion criteria: "Poor metabolic control" despite glibenclamide } 15 \mathrm{mg} / \mathrm{day} \text {, normal bodyweight (IBW } \\
\pm 10 \% \text {, Metropolitan Life Insurance tables) } \\
\text { Exclusion criteria: Ischaemic heart disease, congestive cardiac failure, "renal impairment", "hepatic impair- } \\
\text { ment", "dyslipidaemia" } \\
\text { Patients randomised: } 10 \\
\text { Nr of patients/group: } 5 \text { / } 5 \\
\text { Drop-outs / loss to follow-up: } 1 \text { non-completer } \\
\text { Nr of patients/group analysed: } 9 \text { (total) } \\
\text { Age (years, mean): } 61 \text { yrs (all subjects) } \\
\text { Sex (\% male): } 60 \% \text { male (all subjects) } \\
\text { Diabetes duration (years): } 12.8 \text { yrs (all subjects) } \\
\text { Diabetes therapy: Glibenclamide } 15 \mathrm{mg} / \text { day (3-month run-in period) }\end{array}$ \\
\hline Interventions & $\begin{array}{l}\text { Group 1: Glibenclamide } 5 \mathrm{mg} \text { tds }+ \text { am ultralente insulin } \\
\text { Group 2: am ultralente insulin alone } \\
\text { Cross-over after } 3 \text { months, no washout period, carry-over effect not described } \\
\text { Glucose targets to which insulin doses were titrated: not stated }\end{array}$ \\
\hline
\end{tabular}

Insulin monotherapy versus combinations of insulin with oral hypoglycaemic agents in patients with type 2 diabetes mellitus (Review)

Copyright (C) 2006 The Cochrane Collaboration. Published by John Wiley \& Sons, Ltd 


\section{Characteristics of included studies (Continued)}

Outcomes

Glycaemia: HbA1c (HPLC method, normal range not given)

Weight: Weight gain (comment only, no data)

Hypoglycaemia: not reported

Insulin amount (E): Mean daily insulin dose at final visit

Well-being: not reported

Treatment Satisfaction: not reported

Adverse effects: not reported

\begin{tabular}{ll}
\hline Notes & $\begin{array}{l}\text { Quality score: } 1 \text { (drop-outs }(\mathrm{n}=1) \text { described) } \\
\text { Sponsoring: not stated } \\
\\
\text { Outcome data extracted from figures. }\end{array}$ \\
\hline Allocation concealment & B \\
\hline
\end{tabular}

\begin{tabular}{|c|c|}
\hline Study & Ravnik-Oblak 1995 \\
\hline Methods & $\begin{array}{l}\text { Design: Randomised crossover controlled trial } \\
\text { Duration: } 2 \times 3 \text { month treatment periods } \\
\text { Randomisation procedure: unclear } \\
\text { Blinding: patients no; care provider no; outcome assessor no. } \\
\text { Intention to treat: Yes }\end{array}$ \\
\hline Participants & $\begin{array}{l}\text { Country: Slovenia } \\
\text { Setting: Secondary care outpatient } \\
\text { Inclusion criteria: HbA1c }>9.0 \% \text { despite glibenclamide } 10 \mathrm{mg} \text { bd, FBG }>10 \mathrm{mmol} / \mathrm{l} \text { (for } 3 \text { months), Age } \\
>35 \text { years, Diabetes duration }>3 \text { years, BMI }<30 \mathrm{~kg} / \mathrm{m} 2 \text {, Fasting C-peptide }>0.3 \mathrm{mmol} / \mathrm{l} \\
\text { Exclusion criteria: Liver disease, renal disease, heart failure, myocardial infarction within } 6 \text { months, medica- } \\
\text { tion with potential to interact with oral hypoglycaemic agents or insulin. } \\
\text { Patients randomised: } 27 \\
\text { Nr of patients/group: } 14 \text { / } 13 \\
\text { Drop-outs / loss to follow-up: nil } \\
\text { Nr of patients/group analysed: } 27 \text { (total) } \\
\text { Age (years, median): } 58 \text { yrs (all subjects) } \\
\text { Sex (\% male): } 56 \% \text { (all subjects) } \\
\text { Diabetes duration (years, median): } 10.5 / 8 \\
\text { Diabetes therapy: glibenclamide } 10 \mathrm{mg} \text { bd (no run-in period) }\end{array}$ \\
\hline Interventions & $\begin{array}{l}\text { Group 1: Glibenclamide } 10 \mathrm{mg} \text { bd }+ \text { insulin (combination of short and intermediate acting insulin (Actrapid } \\
\text { HM, Protophane HM (Novo Nordisk) once or twice daily) } \\
\text { Group 2: Insulin alone } \\
\text { Cross-over after } 3 \text { months, no wash-out period, carry-over effect not described. } \\
\text { Glucose targets to which insulin doses were titrated: not stated }\end{array}$ \\
\hline Outcomes & $\begin{array}{l}\text { Glycaemia: HbA1c (normal range }<6.5 \% \text {, HPLC assay) } \\
\text { Weight: BMI } \\
\text { Insulin amount (E): Median daily insulin dose at final visit } \\
\text { Hypoglycaemia: not reported } \\
\text { Well-being: not reported } \\
\text { Treatment Satisfaction: not reported } \\
\text { Adverse events: not reported }\end{array}$ \\
\hline Notes & $\begin{array}{l}\text { Quality score: } 2 \text { (no drop-outs, therefore also ITT analysis) } \\
\text { Sponsoring: not stated } \\
\text { Outcome data extracted from figures. } \\
\text { Data expressed as median values }\end{array}$ \\
\hline Allocation concealment & B \\
\hline
\end{tabular}

Insulin monotherapy versus combinations of insulin with oral hypoglycaemic agents in patients with type 2 diabetes mellitus (Review) 


\section{Characteristics of included studies (Continued)}

\section{Study}

Methods

\section{Riddle 1989}

Design: Randomised crossover controlled trial

Duration: $2 \mathrm{x} 4$ month treatment periods

Randomisation procedure: Performed centrally by drug manufacturer (sequentially numbered supplies of study drug matched to subjects place in sequence of enrolment).

Blinding: patients yes; care provider yes; outcome assessor yes.

Intention to treat: No

Participants

Country: Oregon, USA

Setting: Secondary care outpatient

Inclusion criteria: Age 40-75 yrs, diabetes (gradual) onset $>35$ yrs of age, diabetes duration $>1$ but $<15$ yrs, weight $<160 \%$ ideal bodyweight (Metropolitan Life Insurance tables, 1983), sub-optimal glycaemic control on current therapy - fasting plasma glucose $>7.8 \mathrm{mmol} / \mathrm{l}$.

Exclusion criteria: Major systemic illness other than diabetes, alcoholism, pancreatitis, pancreatic resection, use of corticosteroids, any disability likely to interfere with adherence to the trial protocol.

Patients randomised: 21

$\mathrm{Nr}$ of patients/group: $10 / 11$

Drop-outs / loss to follow-up: $0 / 1$

$\mathrm{Nr}$ of patients/group analysed: 10/10

Age (years, mean): 61 yrs (all subjects)

Sex (\% male): $40 \%$ male (all subjects)

Diabetes duration (years, mean): 6 years

Diabetes therapy: Glibenclamide $10 \mathrm{mg}$ bd (2-8 week run-in period)

\begin{tabular}{ll}
\hline Interventions & Group 1: Glibenclamide $10 \mathrm{mg}+$ evening porcine NPH (Insulatard, Novo Nordisk) \\
& Group 2: Placebo + evening porcine NPH \\
& Crossover after 4 months, no washout period, treatment effect described \\
& Glucose targets to which insulin doses were titrated: Insulin increased at the physicians' discretion aiming \\
& for "excellent glycaemic control". \\
\hline Outcomes & Glycaemia: HbA1 (thiobarbituric acid method, normal range 5.3-8.9\%), FPG \\
& Weight: Weight gain \\
& Insulin amount (E): Mean daily insulin dose at final visit \\
& Hypoglycaemia: Mentioned in text, no data \\
& Well-being: not reported \\
& Treatment Satisfaction: not reported \\
& Adverse events: Reported \\
& Quality score: 6 (not ITT) \\
& Sponsoring: Financial support from Upjohn and the American Diabetes Association Oregon Affiliate \\
\hline Notes & A
\end{tabular}

Study

Riddle 1992

Methods

Design: Double-blind randomised placebo-controlled trial

Duration: 16 weeks

Randomisation procedure: Randomised at time of entry into the treatment protocol by assignment of a study number corresponding to a treatment code determined by the drug manufacturer.

Blinding: patients yes; care provider yes; outcome assessor yes.

Intention to treat: Yes

Participants Country: Oregon, USA

Setting: Secondary care outpatient

Inclusion criteria: Diabetes of gradual onset $>40 \mathrm{yrs}$ of age, diabetes duration $>1 \mathrm{yr}$, fasting plasma glucose $>7.8 \mathrm{mmol} / \mathrm{l}$ despite glibenclamide $10 \mathrm{mg}$ bd.

Exclusion criteria: Major systemic illness other than diabetes. Use of corticosteroids, oestrogen, thyroxine, Adrenergic blockers or diuretics within 1 month of study entry. Patients randomised: 21

Insulin monotherapy versus combinations of insulin with oral hypoglycaemic agents in patients with type $\mathbf{2}$ diabetes mellitus (Review) 


\section{Characteristics of included studies (Continued)}

\begin{tabular}{|c|c|}
\hline & $\begin{array}{l}\mathrm{Nr} \text { of patients/group: } 11 / 10 \\
\text { Drop-outs / loss to follow-up: nil } \\
\mathrm{Nr} \text { of patients/group analysed: } 11 / 10 \\
\text { Age (years, mean): } 55 \text { / } 52 \mathrm{yrs} \\
\text { Sex (\% male): not stated } \\
\text { Diabetes duration (years): } 6 \text { / } 4 \\
\text { Diabetes therapy: glibenclamide } 10 \mathrm{mg} \text { bd (3-week run-in period) }\end{array}$ \\
\hline Interventions & $\begin{array}{l}\text { Group 1: Glibenclamide } 10 \mathrm{mg} \text { pre-breakfast }+ \text { suppertime Novolin } 70: 30 \text { insulin (Novo Nordisk human } \\
70 \% \mathrm{NPH}, 30 \% \text { soluble) } \\
\text { Group 2: Placebo + suppertime } 70: 30 \text { insulin } \\
\text { Glucose targets to which insulin doses were titrated: } \\
\text { Subjects asked to measure capillary blood glucose }(\mathrm{CPG}) \text { daily before breakfast and supper } \\
\text { Insulin starting dose }+30 \text { units, increased weekly, } \\
\text { If mean CBG > } 10 \mathrm{mmol} / \mathrm{l} \text {, insulin increased by } 20 \text { units } \\
\text { CBG 7.8-10, insulin increased by } 15 \text { units } \\
\text { CBG 6.7-7.8 mmol/l, insulin increased by } 10 \text { units } \\
\text { CBG 5.6- } 6.7 \mathrm{mmol} / 1 \text {, insulin increased by } 5 \text { units } \\
\text { If recurrent hypoglycaemic symptoms, or repeated CBG }<3.3 \mathrm{mmol} / \mathrm{l} \text {, reduce by } 5-10 \text { units }\end{array}$ \\
\hline Outcomes & $\begin{array}{l}\text { Glycaemia: HbA1 (thiobarbituric acid method, normal range 5.3-8.9\%), FPG } \\
\text { Weight: Weight gain } \\
\text { Insulin amount (E): Mean daily insulin dose at final visit } \\
\text { Hypoglycaemia: Symptomatic hypoglycaemic episodes } \\
\text { Well-being: not reported } \\
\text { Treatment Satisfaction: not reported } \\
\text { Adverse events: not reported }\end{array}$ \\
\hline Notes & $\begin{array}{l}\text { Quality score: } 7 \\
\text { Sponsoring: Support by a research grant from Hoechst-Roussel Pharmaceuticals } \\
\text { Structured insulin titration regimen }\end{array}$ \\
\hline Allocation concealment & A \\
\hline Study & Riddle 1998 \\
\hline Methods & $\begin{array}{l}\text { Design: Double-blind randomised placebo-controlled trial } \\
\text { Duration: } 24 \text { weeks } \\
\text { Randomisation procedure: not stated } \\
\text { Blinding: patients yes; care provider yes; outcome assessor yes. } \\
\text { Intention to treat: Yes }\end{array}$ \\
\hline Participants & $\begin{array}{l}\text { Country: Oregon, USA } \\
\text { Setting: Secondary care outpatient } \\
\text { Inclusion criteria: Age } 45-70 \text { yrs, weight } 130-170 \% \text { IBW, FPG 10.0-16.7 mmol/l with glimepiride } 8 \mathrm{mg} \text { bd, } \\
\text { adequate contraception } \\
\text { Exclusion criteria: Pregnancy, breast feeding, DM duration > } 15 \mathrm{yrs,} \mathrm{history} \mathrm{of} \mathrm{ketoacidosis,} \mathrm{autoimmune} \\
\text { disease, any major systemic illness other than diabetes, allergy or intolerance to sulphonylureas, use of } \\
\text { glucocorticoids, phenytoin, nicotinic acid, sympathomimetics, phenothiazines, isoniazid. Serum creatinine } \\
\text { or serum alanine aminotransferase }>1.5 \text { times upper limit of normal; fasting C-peptide }<0.4 \mathrm{pmol} / \mathrm{l} \text {. } \\
\text { Patients randomised: } 145 \\
\text { Nr of patients/group: } 72 \text { / } 73 \\
\text { Drop-outs / loss to follow-up: } 2 / 11 \\
\text { Nr of patients/group analysed: } 72 / 73 \\
\text { Age (years, mean): } 58 / 58 \mathrm{yrs} \\
\text { Sex (\% male): } 63 \% \text { / } 55 \%\end{array}$ \\
\hline
\end{tabular}

Insulin monotherapy versus combinations of insulin with oral hypoglycaemic agents in patients with type 2 diabetes mellitus (Review) 


\section{Characteristics of included studies (Continued)}

Diabetes duration (years): $7 / 7 \mathrm{yrs}$

Diabetes therapy: Glimepiride $8 \mathrm{mg}$ bd (8-week run-in period)

Intervention

Group 1: Glimepiride $8 \mathrm{mg}$ bd + suppertime 70:30 insulin (70\%NPH / 30\% regular human insulin)

Group 2: Placebo + suppertime 70:30 insulin

Glucose targets to which insulin doses were titrated: FBG 5.5-6.7 mmol/l

Subjects asked to measure capillary blood glucose (CPG) daily before breakfast and supper

Insulin starting dose $=10$ units for 2 weeks, then Increased weekly

by 10 units until FBG $<7.8 \mathrm{mmol} / \mathrm{l}$ for 2 consecutive days then,

by 5 units until $\mathrm{FBG}<6.7 \mathrm{mmol} / \mathrm{l}$ for 2 consecutive days then

Small reductions allowed if hypoglycaemic symptoms occurred

\begin{tabular}{ll}
\hline Outcomes & Glycaemia: HbA1c (HPLC assay, normal range 4-6\%), FPG \\
& Weight: Weight gain \\
& Insulin amount (E): Mean daily insulin dose at final visit \\
& Hypoglycaemia: Symptomatic hypoglycaemic episodes \\
& Well-being: not reported \\
& Treatment Satisfaction: not reported \\
& Adverse events: Reported \\
\hline Notes & Quality score: 6 (randomisation method not stated) \\
& Sponsoring: Support by a research grant from Hoechst Marion Roussel Pharmaceuticals \\
& Structured insulin titration regimen \\
\hline Allocation concealment & A \\
\hline
\end{tabular}

\begin{tabular}{|c|c|}
\hline Study & Shank 1995 \\
\hline Methods & $\begin{array}{l}\text { Design: Double-blind randomised placebo-controlled trial } \\
\text { Duration: } 6 \text { months } \\
\text { Randomisation procedure: Randomisation code } \\
\text { Blinding: patients yes; care provider yes; outcome assessor yes. } \\
\text { Intention to treat: No }\end{array}$ \\
\hline Participants & $\begin{array}{l}\text { Country: Texas, USA } \\
\text { Setting: Secondary care outpatient } \\
\text { Inclusion criteria: FPG }>7.77 \mathrm{mmol} / \mathrm{l} \text { with max. Dose of sulphonylurea, FPG }<15.54 \mathrm{mmol} / \mathrm{l} \text { without } \\
\text { sulphonylurea. } \\
\text { Exclusion criteria: Other medication known to affect glucose metabolism, prior insulin treatment, regular } \\
\text { vigorous exercise, other major illness other than diabetes. } \\
\text { Patients randomised: } 30 \\
\text { Nr of patients/group: } 10 / 10 / 10 \\
\text { Drop-outs / loss to follow-up: } 1 / 1 / 0 \\
\text { Nr of patients/group analysed: } 9 / 9 / 10 \\
\text { Age (years, mean): } 53 \text { yrs (all subjects) } \\
\text { Sex (\% male): not given } \\
\text { Diabetes duration (years): not stated } \\
\text { Diabetes therapy: Glipizide } 20 \mathrm{mg} \text { bd (2-month run-in period) }\end{array}$ \\
\hline Interventions & $\begin{array}{l}\text { Group 1: Glipizide } 20 \mathrm{mg} \text { bd + bedtime NPH insulin (Novolin-N, Novo Nordisk) } \\
\text { Group 2: Placebo + bedtime NPH insulin } \\
\text { Group 3: Glipizide } 20 \mathrm{mg} \text { bd } \\
\text { Glucose targets to which insulin doses were titrated: first } 3 \text { months, insulin given as } 5 \text { units / } 1.73 \mathrm{~m} 2 \text { and } \\
\text { titrated to } 20 \text { units / } 1.73 \mathrm{~m} 2 \text { (low-dose) } \\
\text { Second } 3 \text { months, target FPG } 3.89-6.66 \mathrm{mmol} / \mathrm{l}\end{array}$ \\
\hline Outcomes & $\begin{array}{l}\text { Glycaemia: HbA1c (microcollumn affinity chromatography, normal range 3.1-6.1\%), FPG } \\
\text { Weight: Weight gain }\end{array}$ \\
\hline
\end{tabular}

Insulin monotherapy versus combinations of insulin with oral hypoglycaemic agents in patients with type 2 diabetes mellitus (Review) 


\section{Characteristics of included studies (Continued)}

Insulin amount (E): Mean daily insulin dose at final visit

Hypoglycaemia: Symptomatic (and asymptomatic $<3.89 \mathrm{mmol} / \mathrm{l}$ ) hypoglycaemic episodes

Well-being: not reported

Treatment Satisfaction: not reported

Adverse events: not reported

\begin{tabular}{|c|c|}
\hline Notes & $\begin{array}{l}\text { Quality score: } 6 \text { (no ITT) } \\
\text { Sponsoring: Support by grants from roerig-Pfizer, Novo Nordisk, Geriatric research and clinical centre, } \\
\text { Veterens Affairs Medical Research Service. }\end{array}$ \\
\hline Allocation concealment & $\mathrm{B}$ \\
\hline Study & Sun 1995 \\
\hline Methods & $\begin{array}{l}\text { Design: Randomised placebo controlled trial } \\
\text { Duration: } 4 \text { months } \\
\text { Randomisation procedure: not stated } \\
\text { Blinding: patients yes; care provider unclear; outcome assessor unclear. } \\
\text { Intention to treat: yes }\end{array}$ \\
\hline Participants & $\begin{array}{l}\text { Country: China } \\
\text { Setting: Secondary care outpatient } \\
\text { Inclusion criteria: Age }>40 \text { yrs, type } 2 \text { diabetes }>5 \text { yrs duration, treatment with max. Sulphonylurea }>3 \\
\text { weeks, FBG }>7.8 \mathrm{mmol} / \mathrm{l}, 2 \mathrm{hr} \text { post-prandial }>11.1 \mathrm{mmol} / \mathrm{l} \text {. } \\
\text { Exclusion criteria: not stated } \\
\text { Patients randomised: } 33 \\
\mathrm{Nr} \text { of patients/group: } 12 / 11 / 10 \\
\text { Drop-outs / loss to follow-up: } 0 / 0 / 0 \\
\text { Nr of patients/group analysed: } 12 / 11 / 10 \\
\text { Age (years, mean): } 53.6 / 54.4 / 54.5 \mathrm{yrs} \\
\text { Sex (\% male): } 50 \% \text { / } 45 \% / 60 \% \mathrm{male} \\
\text { Diabetes duration (years): not stated } \\
\text { Diabetes therapy: Gliquidone } 60 \mathrm{mg} \text { tds, } 3 \text { weeks run-in }\end{array}$ \\
\hline Interventions & $\begin{array}{l}\text { Group 1: Gliquidone } 60 \mathrm{mg} \text { tds }+ \text { bedtime NPH }(0.4 \text { units } / \mathrm{kg} \text {, Novo Nordisk }) \\
\text { Group 2: Placebo + NPH (0.4 units } / \mathrm{kg}) \\
\text { Group 3: Gliquidone } 60 \mathrm{mg} \text { tds } \\
\text { Glucose targets to which insulin doses were titrated: not stated }\end{array}$ \\
\hline Outcomes & $\begin{array}{l}\text { Glycaemia: HbA1c (method not given, normal range }<6 \% \text { ), FBG } \\
\text { Weight: not reported } \\
\text { Insulin amount (E): not given } \\
\text { Hypoglycaemia: Symptomatic hypoglycaemic episodes } \\
\text { Well-being: not reported } \\
\text { Treatment Satisfaction: not reported } \\
\text { Adverse events: not reported }\end{array}$ \\
\hline Notes & $\begin{array}{l}\text { Quality score: } 3 \\
\text { Sponsoring: Supported by Novo Nordisk and Boehringer Ingelheim. }\end{array}$ \\
\hline Allocation conc & B \\
\hline
\end{tabular}

\begin{tabular}{ll} 
Study & Wolffenbuttel 1991 \\
\hline Methods & Design: randomised controlled trial \\
& Duration: 6 months \\
& Randomisation procedure: "aselect assignment" \\
& Blinding: patients no; care provider no; outcome assessor no \\
\hline
\end{tabular}

Insulin monotherapy versus combinations of insulin with oral hypoglycaemic agents in patients with type 2 diabetes mellitus (Review) 33 


\section{Characteristics of included studies (Continued)}

\begin{tabular}{|c|c|}
\hline & Intention to treat: unclear \\
\hline Participants & $\begin{array}{l}\text { Country: Netherlands } \\
\text { Setting: secondary care outpatient } \\
\text { Inclusion criteria: FBG > } 8.0 \mathrm{mmol} / \mathrm{l} \text {; maximal dosage SU (glibenclamide) and/or metformin } \\
\text { Exclusion criteria: unclear } \\
\text { Patients randomised: } 47 \\
\text { Nr of patients/group: } 22 \text { / } 25 \\
\text { Drop-outs / loss to follow-up: } 0 \text { / } 0 \\
\text { Nr of patients/group analysed: } 22 \text { / } 25 \\
\text { Age (years): } 70 \text { / } 68 \\
\text { Sex (\% male): } 83 \text { / } 47 \\
\text { Diabetes duration (median; years): } 9 \text { / } 10 \\
\text { Diabetes therapy: glibenclamide } 15 \mathrm{mg}(27 \text { patients); glibenclamide } 15 \mathrm{mg}+\text { metformin (dose not reported) } \\
\text { (20 patients) }\end{array}$ \\
\hline Interventions & $\begin{array}{l}\text { Group 1: intermediate-acting insulin (NPH) before breakfast and dinner; eventually replaced by mixed } \\
\text { insulin (30\% short-acting and 70\% intermediate-acting) in case of post-prandial BG }>10.0 \mathrm{mmol} / \mathrm{l} \\
\text { Group 2: intermediate-acting insulin (NPH) before breakfast or bedtime + glibenclamide } 15 \mathrm{mg} \text {; eventually } \\
\text { a second injection was added in case of post-prandial BG }>10.0 \mathrm{mmol} / 1 \\
\text { Glucose targets to which insulin doses were titrated: } \mathrm{FBG}<7.0 \mathrm{mmol} / \mathrm{l} \text {; post-prandial } \mathrm{BG}<10.0 \mathrm{mmol} / \mathrm{l} \text {; } \\
\text { HbAlc }<8.0 \%\end{array}$ \\
\hline Outcomes & $\begin{array}{l}\text { Glycaemia: FBG; HbAlc } \\
\text { Weight: weight } \\
\text { Insulin amount (E): daily dose } \\
\text { Hypoglycaemia: reported qualitatively } \\
\text { Well-being: reported qualitatively } \\
\text { Treatment Satisfaction: not reported } \\
\text { Adverse events: not reported }\end{array}$ \\
\hline Notes & $\begin{array}{l}\text { Quality score: } 0 \\
\text { Sponsoring: Novo Nordisk Pharmaceuticals, Diabetes Research Fund }\end{array}$ \\
\hline alment & B \\
\hline
\end{tabular}

\begin{tabular}{ll} 
Study & Wolffenbuttel 1996 \\
\hline Methods & Design: Randomised controlled trial \\
& Duration: 6 months \\
& Randomisation procedure: not stated \\
& Blinding: patients no; care provider no; outcome assessor no. \\
& Intention to treat: no \\
\hline Participants & Country: Netherlands \\
& Setting: Secondary care outpatient \\
& Inclusion criteria: Fasting blood glucose (mean of 3 measurements) $>8.0$ mmol/l, HbA1c $>8.9 \%$ despite \\
& diet \& max. oral hypoglycaemic agents (glibenclamide 15 mg / day \pm metformin). \\
& Exclusion criteria: Intercurrent illness, cardiac, hepatic, renal or other endocrine disease. Severe untreated \\
& hypertension (diastolic BP > 110 mm Hg), impaired renal function (creatinine $>140$ micromol/l), or \\
& treatment with corticosteroids. \\
& Patients randomised: 102 \\
& Nr of patients/group: $34 / 28 / 33$ \\
& Drop-outs / loss to follow-up: 7 (unclear which group(s)) \\
& Nr of patients/group analysed: $34 / 28 / 33$ \\
& Age (years, mean): 68 yrs (completers) \\
& Sex (\% male): $39 \%$ male (completers) \\
& Diabetes duration (years): median 9 yrs (completers) \\
\hline
\end{tabular}




\section{Characteristics of included studies (Continued)}

Diabetes therapy: Glibenclamide $15 \mathrm{mg} /$ day ( $\mathrm{n}=66)$, Glibenclamide $15 \mathrm{mg} /$ day + metformin $(\mathrm{n}=29)$

Interventions

Group 1: Twice-daily insulin mixture (Mixtard 30/70, 30\% short acting, 70\% NPH, Novo Nordisk)

Group 2: Glibenclamide $10 \mathrm{mg}+5 \mathrm{mg}+$ bedtime NPH insulin

Group 3: Glibenclamide $10 \mathrm{mg}+5 \mathrm{mg}+\mathrm{NPH}$ insulin before breakfast

Glucose targets to which insulin doses were titrated:

Fasting blood glucose $<7.0 \mathrm{mmol} / \mathrm{l}$, pre-prandial glucose $<10 \mathrm{mmol} / \mathrm{l}, \mathrm{HbA} 1 \mathrm{c}<8.0 \%$.

If daytime/evening (group 2) or bedtime (group 3) blood glucose exceeded $10 \mathrm{mmol} / \mathrm{l}$, subjects were switched to a regimen consisting of NPH insulin before breakfast and at bedtime with continued glibenclamide

\begin{tabular}{ll}
\hline Outcomes & Glycaemia: HbA1c (HPLC assay, normal range 4.4-6.2\%), FBG \\
& Weight: Weight gain \\
& Insulin amount (E): Mean daily insulin dose at final visit \\
& Hypoglycaemia: Severe hypoglycaemic episodes reported \\
& Well-being: not formally reported \\
& Treatment Satisfaction: not formally reported \\
& Adverse events: Reported \\
\hline Notes & Quality score: 1 ? ( withdrawals \& dropouts described?) \\
& Sponsoring: Supported by Novo Nordisk and Boehringer Ingelheim. \\
\hline Allocation concealment & B \\
\hline
\end{tabular}

\begin{tabular}{|c|c|}
\hline Study & Xu 2001 \\
\hline Methods & $\begin{array}{l}\text { Design: Randomised controlled trial } \\
\text { Duration: } 6 \text { months } \\
\text { Randomisation procedure: unclear } \\
\text { Blinding: unclear } \\
\text { Intention to treat: unclear }\end{array}$ \\
\hline Participants & $\begin{array}{l}\text { Country: China } \\
\text { Setting: Sec care outpat and sec inpat } \\
\text { Inclusion criteria: data missing } \\
\text { Exclusion criteria: data missing } \\
\text { Patients randomised: } 90 \\
\text { Nr of patients/group: } 45 \text { / } 45 \\
\text { Drop-outs / loss to follow-up: } 0 \text { / } 0 \\
\text { Nr of patients/group analysed: } 45 \text { / } 45 \\
\text { Age (years, mean): } 51.4 \text { / } 52.1 \\
\text { Sex (\% male): } 47 \text { / } 51 \\
\text { Diabetes duration (years;(SD)): } 7.3 \text { (4.5) / } 7.4 \text { (4.8) } \\
\text { Diabetes therapy: OHAs }\end{array}$ \\
\hline Interventions & $\begin{array}{l}\text { Group 1: insulin once daily } 24 \mathrm{IU} / \text { day } \\
\text { Group 2: metformin } 1500 \text { daily + insulin once daily } 24 \mathrm{U} / \text { day } \\
\text { Glucose targets to which insulin doses were titrated: } 3.5-7.0 \mathrm{mmol} / \mathrm{l}\end{array}$ \\
\hline Outcomes & $\begin{array}{l}\text { Glycaemia: HbA1c (method and normal range not given), FBG } \\
\text { Weight: data missing } \\
\text { Insulin amount (IU): fixed insulin dose in both groups } \\
\text { Hypoglycaemia: not reported } \\
\text { Well-being: not reported } \\
\text { Treatment Satisfaction: not reported } \\
\text { Adverse events: not reported }\end{array}$ \\
\hline Notes & $\begin{array}{l}\text { Quality score: } 0 \\
\text { Sponsoring: unclear }\end{array}$ \\
\hline
\end{tabular}

Insulin monotherapy versus combinations of insulin with oral hypoglycaemic agents in patients with type 2 diabetes mellitus (Review) 


\section{Characteristics of included studies (Continued)}

Allocation concealment $\mathrm{B}$

\begin{tabular}{|c|c|}
\hline Study & Yki-Järvinen 1992 \\
\hline Methods & $\begin{array}{l}\text { Design: Randomised controlled trial } \\
\text { Duration: } 3 \text { months }\end{array}$ \\
\hline Participants & 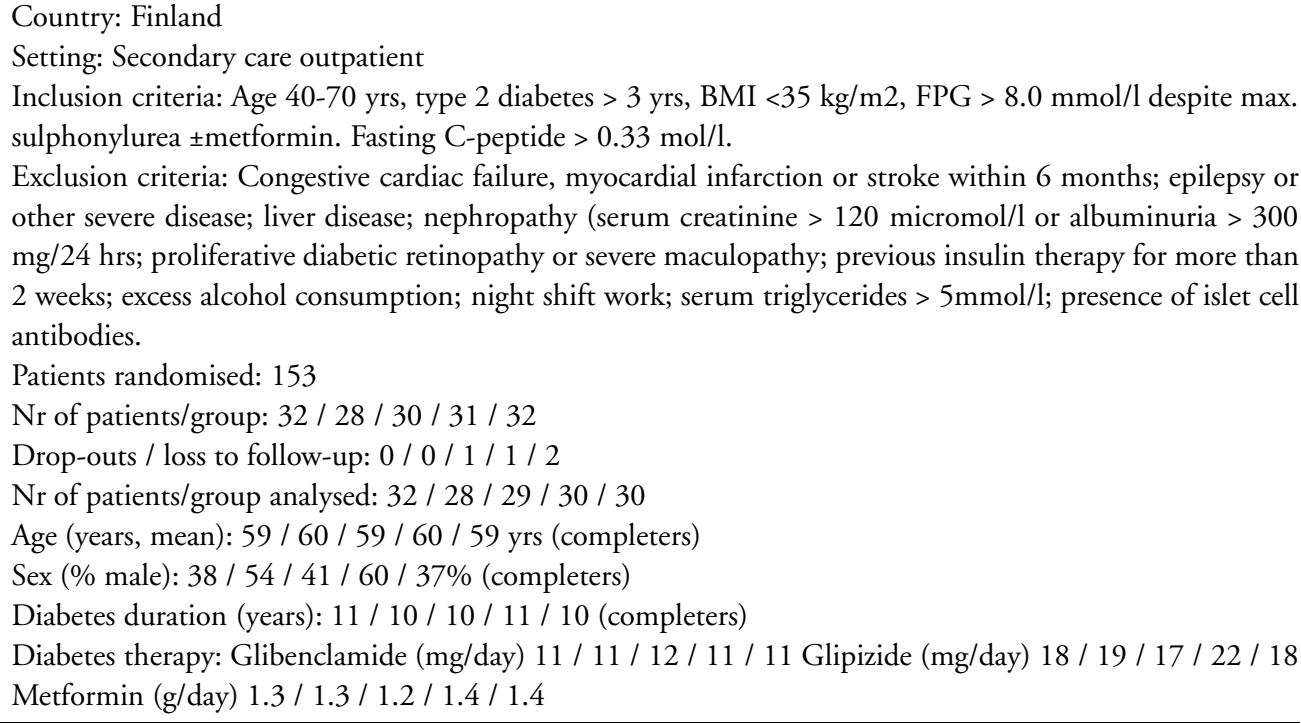 \\
\hline Interventions & 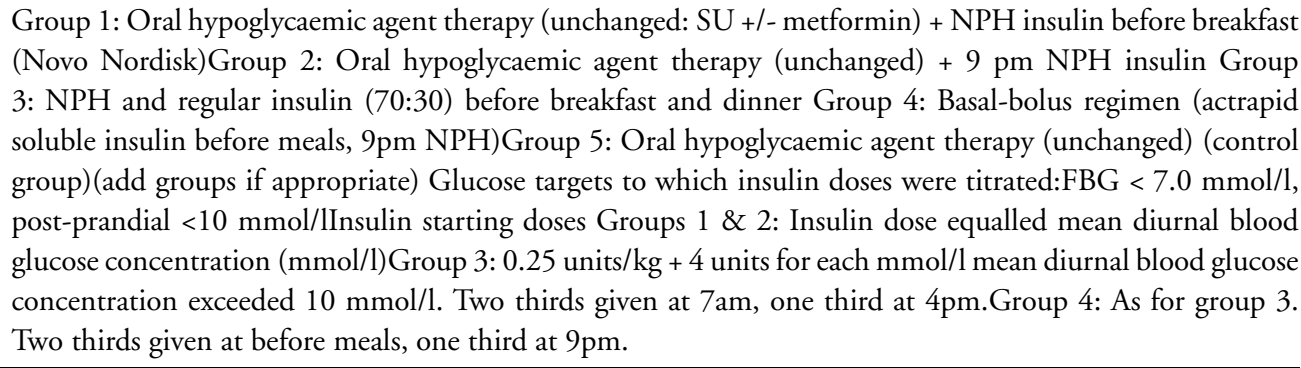 \\
\hline Outcomes & $\begin{array}{l}\text { Glycaemia: HbA1c (HPLC assay, 4-6\%), FBG } \\
\text { Weight: Weight gain } \\
\text { Insulin amount (E): Mean daily insulin dose at final visit } \\
\text { Hypoglycaemia: Symptomatic and biochemical }(<4.0 \mathrm{mmol} / \mathrm{l}) \text { hypoglycaemia } \\
\text { Well-being: Reported though method not stated } \\
\text { Treatment Satisfaction: not reported } \\
\text { Adverse events: Those resulting in withdrawal reported }\end{array}$ \\
\hline Notes & $\begin{array}{l}\text { Quality score: } 4 \\
\text { Sponsoring: Supported by grants from Novo Nordisk, Finnish State Medical Research Council, Sigrid Juselius } \\
\text { research foundation. }\end{array}$ \\
\hline & \\
\hline
\end{tabular}

\begin{tabular}{ll} 
Study & Yki-Järvinen 1999 \\
\hline Methods & Design: Randomised placebo controlled trial \\
& Duration: 1 year \\
& Randomisation procedure: "minimization of differences" \\
& Blinding: patients yes; care provider no; outcome assessor no. \\
& Intention to treat: no \\
\hline
\end{tabular}




\section{Characteristics of included studies (Continued)}

Participants

Country: Finland

Setting: Secondary care outpatient

Inclusion criteria: Age 40-70 yrs, $\mathrm{BMI}<35 \mathrm{~kg} / \mathrm{m} 2, \mathrm{FBG}>8.0 \mathrm{mmol} / \mathrm{l}$, diabetes duration $>3$ yrs, previous oral therapy with max. SU (glipizide $>15 \mathrm{mg} /$ day, glibenclamide $>10 \mathrm{mg} /$ day. Fasting C-peptide $>0.33 \mathrm{nmol} / \mathrm{l}$. Exclusion criteria: NYHA grade III/IV heart failure, MI or stroke within 6 months, epilepsy or other severe disease, liver disease unrelated to diabetes, nephropathy (macroalbuminuria or serum creatinine $>120$ micromol/l, proliferative retinopathy or severe maculopathy, insulin theraspy for more than 2 weeks, excessive alcohol consumption, night shift work.

Patients randomised: 96

$\mathrm{Nr}$ of patients/group: 24 / 24 / 24 / 24

Drop-outs / loss to follow-up: $2 / 5 / 1 / 0$

$\mathrm{Nr}$ of patients/group analysed: $22 / 19 / 23 / 24$

Age (years, mean): $61 / 57 / 55 / 58$ yrs (completers)

Sex (\% male): 59 / $58 / 61 / 67 \%$ (completers)

Diabetes duration (years): not stated

Diabetes therapy: glipizide $>15 \mathrm{mg} /$ day, glibenclamide $>10 \mathrm{mg} /$ day

Interventions Group 1: Glibenclamide $3.5 \mathrm{mg}+7 \mathrm{mg}+$ bedtime NPH insulin (+ metformin placebo)

Group 2: Metformin $1 \mathrm{~g}$ bd + bedtime NPH insulin (+ glibenclamide placebo)

Group 3: Glibenclamide $(3.5 \mathrm{mg}+7 \mathrm{mg})+$ metformin $(1 \mathrm{~g} \mathrm{bd})+$ bedtime NPH insulin

Group 4: BD NPH insulin

Glucose targets to which insulin doses were titrated:

FPG $<6.0 \mathrm{mmol} / 1$

Starting dose of NPH = FPG (mmol/l), FPG measured daily. Insulin increased by 4 units if 3 successive FPG readings $>8 \mathrm{mmol} / \mathrm{l}$, and 2 units if $>6.0 \mathrm{mmol} / \mathrm{l}$

Outcomes Glycaemia: HbA1c (HPLC method, normal range not given), FPG

Weight: Weight gain, BMI

Insulin amount (E): Mean daily insulin dose at final visit

Hypoglycaemia: not reported

Well-being: not reported

Treatment Satisfaction: not reported

Adverse events: Reported

Notes

Quality score: 4

Sponsoring: Supported by grant from the Acadamy of Finland

Structured patient-led insulin titration regimen

Allocation concealment A

Abbreviations: $\mathrm{BMI}=$ body mass index, $\mathrm{CCF}=$ congestive cardiac failure, $\mathrm{CPG}=$ capillary blood glucose, $(\mathrm{F}) \mathrm{BG}=($ fasting$)$ blood glucose, $\mathrm{FPG}=$

fasting plasma glucose, HPLC = high performance liquid chromatography, IBW = ideal bodyweight, $\mathrm{MI}=$ myocardial infarction, $\mathrm{NPH}=$ neutral protamine hegedorn, $\mathrm{OHA}=$ oral hypoglycaemic agents, $\mathrm{PVD}=$ peripheral vascular disease, $\mathrm{SU}=$ sulphonylurea

\section{Characteristics of excluded studies}

\begin{tabular}{ll} 
Allen 1985 & previously insulin-treated \\
\hline Aviles 1999 & previously insulin-treated \\
\hline Bastyr 2000 & no insulin monotherapy arm \\
\hline Bieger 1984 & previously insulin-treated \\
\hline Birkeland 1994 & no insulin / oha combination therapy arm \\
\hline Birkeland 1996 & no insulin / oha combination therapy arm \\
\hline Bruns 1988 & not a RCT; follow-up < 2 months \\
\hline Insulin monotherapy versus combinations of insulin with oral hypoglycaemic agents in patients with type 2 diabetes mellitus (Review) & $\mathbf{3 7}$ \\
Copyright @ 2006 The Cochrane Collaboration. Published by John Wiley \& Sons, Ltd
\end{tabular}




\section{Characteristics of excluded studies (Continued)}

Calle 1995

no insulin / oha combination therapy arm

Camerini 1994 previously insulin-treated (62\% of patients)

Carta $1984 \quad$ not a RCT

Casner $1988 \quad$ previous insulin-treated

Castillo 1987 previously insulin-treated

Chazan $2001 \quad$ not a RCT

Chiasson 1994 no insulin monotherapy arm

Clauson 1996 previously insulin-treated

Cortes $1993 \quad$ patients well-controlled at inclusion

Diehl 1985 no insulin / oha combination therapy arm

Elgrably $1991 \quad$ not a RCT

Falko $1985 \quad$ previously insulin-treated

Feinglos 1997 no insulin monotherapy arm

Feinglos $1998 \quad$ previously insulin-treated

Firth 1986 no insulin /oha combination therapy arm

Firth 1987 no insulin /oha combination therapy arm

Fonseca $2000 \quad$ previously insulin-treated

Fritsche $2000 \quad$ previously insulin-treated

Giugliano 1993 previously insulin-treated

Groop $1984 \quad$ previously insulin-treated

Groop $1985 \quad$ previously insulin-treated

Groop 1989 no insulin / oha combination therapy arm

Groop 1991 no insulin /oha combination therapy arm

Groop 1992 no insulin monotherapy arm

Guvener $1999 \quad$ previously insulin-treated

Hamelbeck 1982 follow-up $<2$ months

Hirsch 1999 previously insulin-treated

Josse $1995 \quad$ previously insulin-treated

Kasim $1986 \quad$ not a RCT

Kelley $1998 \quad$ previously insulin-treated

Kitabchi $1987 \quad$ previously insulin-treated

Klein $1991 \quad$ no insulin monotherapy arm

Kyllastinen 1985 previously insulin-treated

Landstedt 1995 previously insulin-treated

Landstedt 1999 previously insulin-treated

Lardinois 1985 previously insulin-treated

Lawrence $1988 \quad$ not a RCT

Lebovitz $1990 \quad$ not a RCT

Lewitt $1989 \quad$ previously insulin-treated

Liedtke $1990 \quad$ follow-up $<2$ months

Lindstrom 1992 no insulin /oha combination therapy arm

Insulin monotherapy versus combinations of insulin with oral hypoglycaemic agents in patients with type $\mathbf{2}$ diabetes mellitus (Review) 38

Copyright $\odot 2006$ The Cochrane Collaboration. Published by John Wiley \& Sons, Ltd 


\section{Characteristics of excluded studies (Continued)}

Lindstrom 1999 previously insulin-treated

Lins $1988 \quad$ previously insulin-treated

Longnecker 1986 previously insulin-treated

Lopez 1999 no insulin /oha combination therapy arm

Martin $1986 \quad$ not a RCT

Mauerhoff $1986 \quad$ previously insulin-treated

Mezitis $1992 \quad$ previous insulin-treated

Mohan $1990 \quad$ previously insulin-treated

Nathan $1988 \quad$ patients on diet alone

Niazi 1998 no insulin monotherapy arm

Niskanen 1992 no insulin / oha combination therapy arm

Okada $1996 \quad$ not a RCT

Osei $1984 \quad$ previously insulin-treated

Panahloo $1998 \quad$ patients on diet alone

Pasmantier $1990 \quad$ study on human pro-insulin

Peacock 1984 no insulin / oha combination therapy arm

Polo 1998 study on combination nicotinamide with insulin

Ponssen $2000 \quad$ previously insulin-treated

Quatraro $1986 \quad$ previously insulin-treated

Raskin $2001 \quad$ previously insulin-treated

Reich $1987 \quad$ previously insulin-treated

Relimpio $1998 \quad$ previously insulin-treated

Rivellese 2000 no insulin / oha combination therapy arm

Robinson $1998 \quad$ previously insulin-treated

Rodier 1995 no insulin / oha combination therapy arm

Romano 1997 no insulin / oha combination therapy arm

Rosak $1985 \quad$ previously insulin-treated

Samanta 1987 newly diagnosed type 2 diabetes patients

Sanchez 1999 previously insulin-treated

Sane 1992 no insulin monotherapy arm

Sangiorgio 1996 no insulin monotherapy arm

Schade 1987 previously insulin-treated

Schwartz 1997 no insulin monotherapy arm

Schwartz $1998 \quad$ previously insulin-treated

Simonson 1987 previously insulin-treated

Simpson $1990 \quad$ previously insulin-treated

Sinagra $1998 \quad$ previously insulin-treated

Soneru 1993 no insulin monotherapy arm

Sotaniemi $1990 \quad$ follow-up $<2$ months

Standl 1999 previously insulin-treated

Stenman $1988 \quad$ previously insulin-treated

Insulin monotherapy versus combinations of insulin with oral hypoglycaemic agents in patients with type 2 diabetes mellitus (Review) 39

Copyright $\odot 2006$ The Cochrane Collaboration. Published by John Wiley \& Sons, Ltd 


\section{Characteristics of excluded studies (Continued)}

\begin{tabular}{ll} 
Stocks 1988 & previously insulin-treated \\
\hline Stradner 1990 & no insulin monotherapy arm \\
\hline Thompson 1998 & previously insulin-treated \\
\hline Tovi 1998 & no insulin / oha combination therapy arm \\
\hline Trischitta 1992 & no insulin monotherapy arm \\
\hline Trischitta 1998 & no insulin monotherapy arm \\
\hline Trznadel 1997 & not a RCT \\
\hline Turner 1999 (2) & no insulin / oha combination therapy arm \\
\hline UKPDS 13 1995 & no insulin / oha combination therapy arm \\
\hline UKPDS 24 1998 & no insulin / oha combination therapy arm \\
\hline UKPDS 33 1998 & no insulin / oha combination therapy arm \\
\hline Vigneri 1991 & no insulin monotherapy arm \\
\hline Wolffenbuttel 1989 & no insulin / oha combination therapy arm \\
\hline Yki-Jarvinen 2000 & no insulin monotherapy arm \\
\hline Yu 1999 & previously insulin-treated \\
\hline Yudkin 2000 & previously insulin-treated \\
\hline
\end{tabular}

\section{A D D I T I O NAL TABLES}

\section{Table 01. Search strategy}

\section{ELECTRONIC SEARCHES:}

Unless otherwise stated, search terms were free text terms; exp = exploded MeSH: Medical subject heading (Medline medical index term); the dollar sign (\$) stands for any character(s); the question mark (?) = to substitute for one or no characters; tw = text word; pt = publication type; $s \mathrm{~h}=\mathrm{MeSH}$ : Medical subject heading (Medline medical index term); adj = adjacency.

1. exp Drug Combinations/

2. (drug therap\$ or drug combination\$).tw.

3. ((combination $\$$ or oral or multiple) adj (therap\$ or agent $\$$ or drug $\$$ or treatment $\$)$ ).tw.

4. monotherap\$.tw.

5. or/1-4

6. $\exp$ SULFONYLUREA COMPOUNDS/

7. $\exp$ BIGUANIDES/

8. $\exp$ ACARBOSE/

9. (biguanid $\$$ or sulfonylurea $\$$ or sulphonylurea $\$$ or acarbose).tw.

10. (gliglacid\$ or glibornurid\$ or gliguidon $\$$ or glisoxepid $\$$ or glipizid $\$$ or gliburid $\$$ or

11. glyburid $\$$ or tolazamid $\$$ ).tw.

12. (tolbutamid $\$$ or carbutamid $\$$ or chlorpropamid $\$$ or acetohexamid $\$$ or glibenclamid $\$$ or

13. glimepirid\$).tw.

14. (metformin \$ or buformin\$ or chlorhexidin\$ or chlorguanid \$ or phenformin\$).tw.

15. (miglitol\$ or nateglinid $\$$ or glucobay).tw.

16. (troglitazon $\$$ or rosiglitazon $\$$ or pioglitazon $\$$ or thioazolidinedion $\$$ or glitazon $\$$ ).tw.

17. repaglinid\$.tw.

18. exp INSULIN/

19. insulin\$.tw.

20. ((antidiabet $\$$ or anti diabet $\$$ ) adj (drug\$ or herb\$ or agent $\$$ or compound $\$))$.tw. 
Table 01. Search strategy (Continued)

21. (hypoglyc?emic adj (drug\$ or herb\$ or agent\$ or compound\$)).tw.

22. or/6-21

23.5 and 22

24. exp diabetes mellitus, non-insulin-dependent/

25. exp insulin resistance/

26. impaired glucose toleranc $\$$.tw.

27. glucose intoleranc $\$$.tw.

28. insulin\$ resistanc\$.tw.

29. exp obesity in diabetes/

30. (obes\$ adj diabet\$).tw.

31. (MODY or NIDDM).tw.

32. (non insulin $\$$ depend $\$$ or noninsulin $\$$ depend $\$$ or noninsulin?depend $\$$ or non

33. insulin?depend\$).tw.

34. ((typ\$ 2 or typ\$ II) adj diabet\$).tw.

35. ((keto?resist\$ or non?keto\$) adj diabet\$).tw.

36. ((adult $\$$ or matur $\$$ or late or slow or stabl\$) adj diabet $\$)$.tw.

37. (insulin\$ defic\$ adj relativ\$).tw.

38. pluri?metabolic\$ syndrom\$.tw.

39. or/24-38

40. exp diabetes insipidus/

41. diabet $\$$ insipidus.tw.

42. 40 or 41

43.39 not 42

44. randomized controlled trial.pt.

45. controlled clinical trial.pt.

46. randomized controlled trials.sh.

47. random allocation.sh.

48. double-blind method.sh.

49. single-blind method.sh.

50. or/44-49

51. limit 50 to animal

52. limit 50 to human

53.51 not 50

54.50 not 53

55. clinical trial.pt.

56. exp clinical trials/

57. (clinic $\$$ adj25 trial\$).tw.

58. ((singl\$ or doubl\$ or trebl\$ or tripl\$) adj (mask\$ or blind $\$))$.tw.

59. placebos.sh.

60. placebo\$.tw.

61. random\$.tw.

62. research design.sh.

63. (latin adj square).tw.

64. or/55-63

65. limit 64 to animal

66. limit 64 to human

67. 65 not 66

68. 64 not 67

69. comparative study.sh.

70. exp evaluation studies/

Insulin monotherapy versus combinations of insulin with oral hypoglycaemic agents in patients with type 2 diabetes mellitus (Review)

Copyright $(2006$ The Cochrane Collaboration. Published by John Wiley \& Sons, Ltd 
Table 01. Search strategy (Continued)

71. follow-up studies.sh.

72. prospective studies.sh.

73. cross-over studies.sh.

74. exp Intervention Studies/

75. or/69-74

76. limit 75 to animals

77. limit 75 to human

78.76 not 77

79. 75 not 78

80.54 or 68 or 79

81.23 and 43 and 80

\section{A N A L Y S E S}

Comparison 01. Insulin once daily versus insulin once daily plus oral antihyperglycaemic agents (OHAs)

\begin{tabular}{lcccc} 
Outcome title & $\begin{array}{c}\text { No. of } \\
\text { studies }\end{array}$ & $\begin{array}{c}\text { No. of } \\
\text { participants }\end{array}$ & Statistical method & Effect size \\
\hline $\begin{array}{l}\text { 01 HbA1c (change from baseline } \\
[\%])\end{array}$ & 5 & 297 & Weighted Mean Difference (Random) 95\% CI & $0.33[0.03,0.62]$ \\
\hline
\end{tabular}

Comparison 02. insulin twice daily versus insulin plus OHAs

\begin{tabular}{|c|c|c|c|}
\hline Outcome title & $\begin{array}{lc}\text { No. of } & \text { No. of } \\
\text { studies } & \text { participants }\end{array}$ & Statistical method & Effect size \\
\hline $\begin{array}{l}01 \mathrm{HbA1c} \text { (change from baseline } \\
{[\%] \text { ) }}\end{array}$ & & Weighted Mean Difference (Random) 95\% CI & Subtotals only \\
\hline $\begin{array}{l}02 \text { weight gain (change from } \\
\text { baseline }[\mathrm{kg}]]\end{array}$ & & Weighted Mean Difference (Random) 95\% CI & Subtotals only \\
\hline
\end{tabular}

\section{Comparison 03. insulin basal/bolus versus insulin plus OHA}

\begin{tabular}{|c|c|c|c|}
\hline Outcome title & $\begin{array}{lc}\text { No. of } & \text { No. of } \\
\text { studies } & \begin{array}{c}\text { participants } \\
\end{array}\end{array}$ & Statistical method & Effect size \\
\hline $\begin{array}{l}01 \mathrm{HbAlc} \text { (change from baseline } \\
{[\%] \text { ) }}\end{array}$ & & Weighted Mean Difference (Random) 95\% CI & Subtotals only \\
\hline $\begin{array}{l}02 \text { weight gain (change from } \\
\text { baseline }[\mathrm{kg}]]\end{array}$ & & Weighted Mean Difference (Random) 95\% CI & Subtotals only \\
\hline
\end{tabular}

Comparison 04. Insulin monotherapy versus insulin plus metformine + /- sulphonylurea (SU)

\begin{tabular}{lcccc} 
Outcome title & $\begin{array}{c}\text { No. of } \\
\text { studies }\end{array}$ & $\begin{array}{c}\text { No. of } \\
\text { participants }\end{array}$ & Statistical method & Effect size \\
\hline $\begin{array}{l}01 \mathrm{HbA1c} \text { (change from baseline } \\
[\%])\end{array}$ & 3 & 153 & Weighted Mean Difference (Random) 95\% CI & $-0.08[-0.78,0.62]$ \\
\hline
\end{tabular}

\section{INDEX TERMS}

\section{Medical Subject Headings (MeSH)}

Diabetes Mellitus, Type 2 [* drug therapy]; Drug Therapy, Combination; Hypoglycemic Agents [* therapeutic use]; Insulin [* therapeutic use]; Randomized Controlled Trials

Insulin monotherapy versus combinations of insulin with oral hypoglycaemic agents in patients with type 2 diabetes 
MeSH check words

Humans

\section{COVER SHEET}

Title

\section{Authors}

Contribution of author(s)

Issue protocol first published

Review first published

Date of most recent amendment

Date of most recent

SUBSTANTIVE amendment

What's New

Date new studies sought but none found

Date new studies found but not yet included/excluded

Date new studies found and included/excluded

Date authors' conclusions section amended

\section{Contact address}

DOI

Cochrane Library number

Editorial group

Editorial group code
Insulin monotherapy versus combinations of insulin with oral hypoglycaemic agents in patients with type 2 diabetes mellitus

Goudswaard AN, Furlong NJ, Valk GD, Stolk RP, Rutten GEHM

AN GOUDSWAARD: Protocol development, searching for trials, trial selection, quality assessment of trials, data extraction, review development.

NJ FURLONG: Quality assessment of trials, data extraction, review development.

GD VALK: Protocol development, trial selection, quality assessment of trials, data extraction, review development.

RP STOLK: Methodology, statistics.

GEHM RUTTEN: Review development.

2002/1

$2004 / 4$

25 May 2005

25 August 2004

Information not supplied by author

Information not supplied by author

Information not supplied by author

Information not supplied by author

Information not supplied by author

Alex Goudswaard

Julius Center for Health Sciences and Primary Care

University Medical Center Utrecht

Koperslagersgilde 5

Houten

$3994 \mathrm{CH}$

NETHERLANDS

E-mail: lex.goudswaard@xs4all.nl

Tel: + 31306378402

Fax: + 31306352717

10.1002/14651858.CD003418.pub2

CD003418

Cochrane Metabolic and Endocrine Disorders Group

HM-ENDOC

Insulin monotherapy versus combinations of insulin with oral hypoglycaemic agents in patients with type 2 diabetes mellitus (Review)

Copyright $\odot 2006$ The Cochrane Collaboration. Published by John Wiley \& Sons, Ltd 


\section{GRAPHS AND OTHER TABLES}

\section{Figure 0I. Funnel plot for the outcome HbAlc}

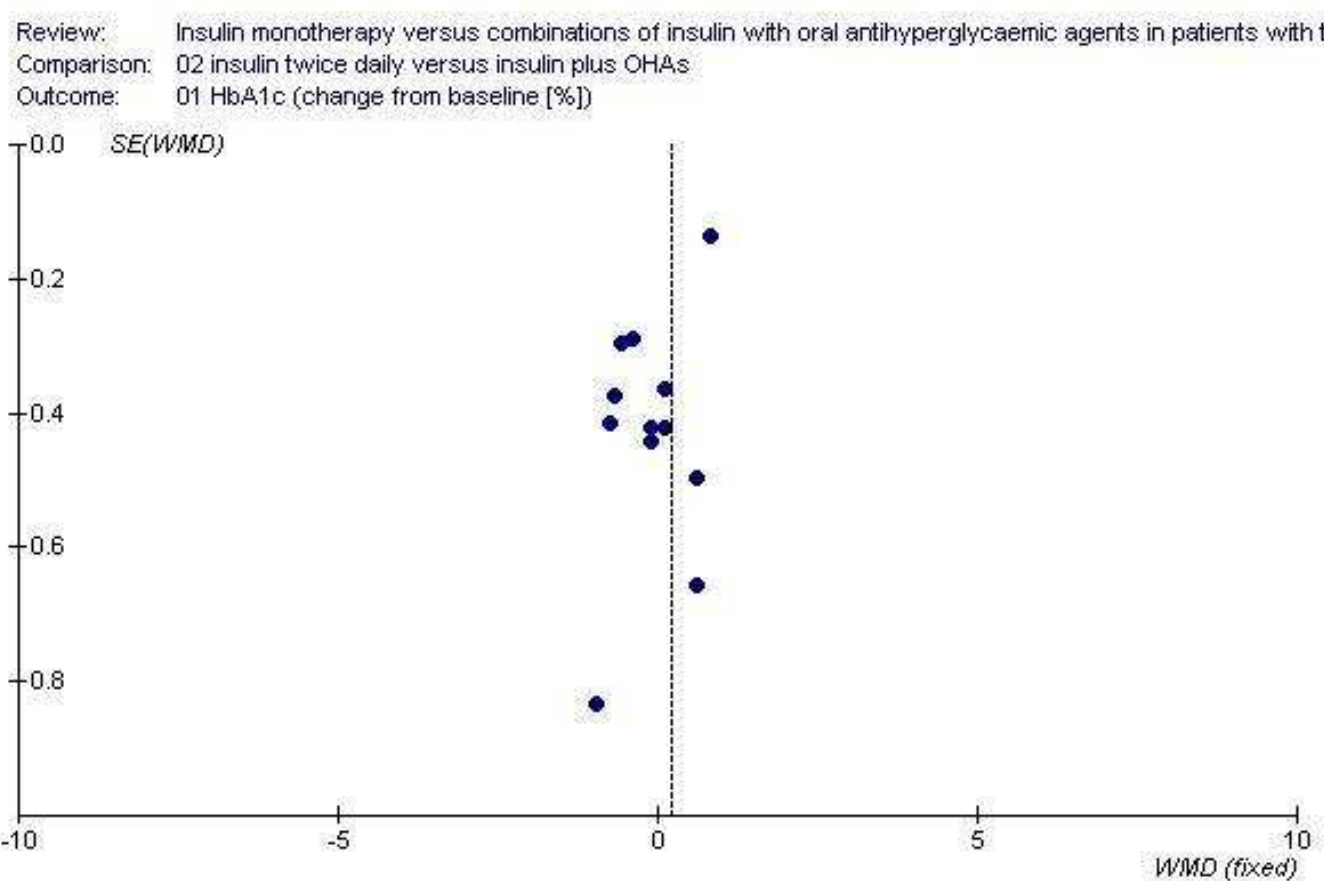


Analysis 01.01 . Comparison $0 \mathrm{I}$ Insulin once daily versus insulin once daily plus oral antihyperglycaemic agents (OHAs), Outcome 0 I HbAlc (change from baseline [\%])

Review: Insulin monotherapy versus combinations of insulin with oral hypoglycaemic agents in patients with type 2 diabetes mellitus

Comparison: $\quad 0$ I Insulin once daily versus insulin once daily plus oral antihyperglycaemic agents (OHAs)

Outcome: $01 \mathrm{HbAlc}$ (change from baseline [\%])

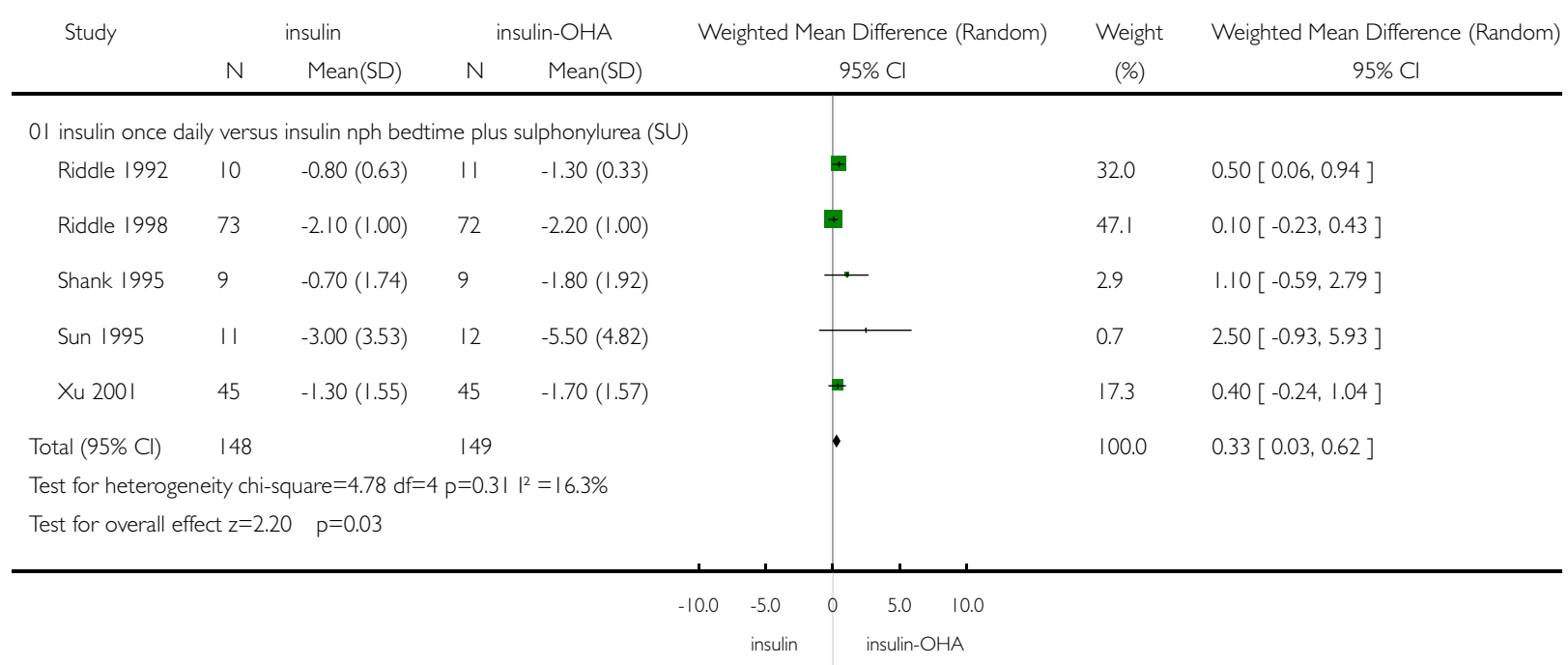

\section{Analysis 02.0I. Comparison 02 insulin twice daily versus insulin plus OHAs, Outcome 01 HbAlc (change from baseline [\%])}

Review: Insulin monotherapy versus combinations of insulin with oral hypoglycaemic agents in patients with type 2 diabetes mellitus

Comparison: 02 insulin twice daily versus insulin plus $\mathrm{OHAs}$

Outcome: $0 \mathrm{I} \mathrm{HbAlc} \mathrm{(change} \mathrm{from} \mathrm{baseline} \mathrm{[ \% ])}$

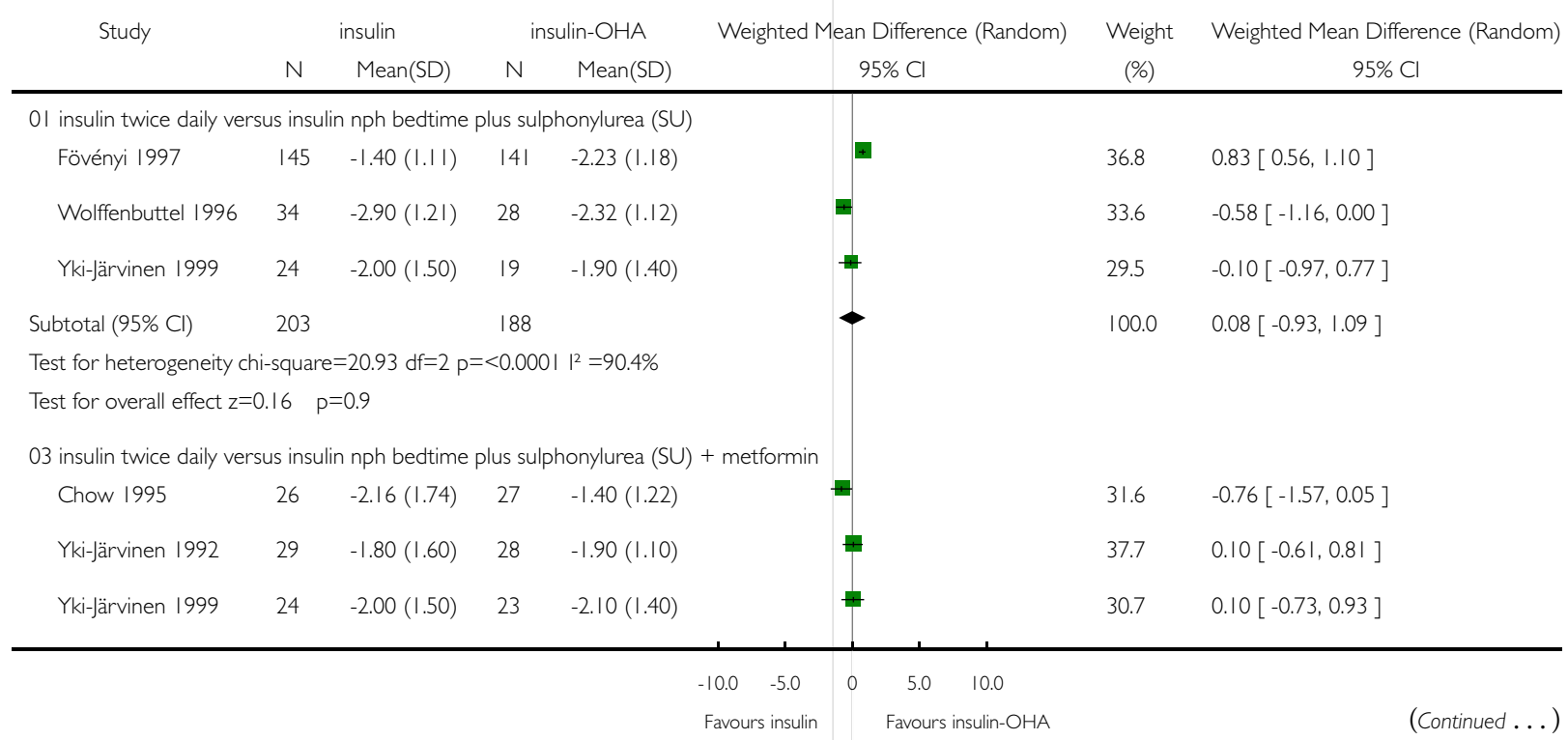

Insulin monotherapy versus combinations of insulin with oral hypoglycaemic agents in patients with type 2 diabetes mellitus (Review) 
(... Continued)

\begin{tabular}{|c|c|c|c|c|c|c|c|}
\hline \multirow[t]{2}{*}{ Study } & \multicolumn{2}{|r|}{ insulin } & \multicolumn{2}{|c|}{ insulin-OHA } & \multirow{2}{*}{$\begin{array}{l}\text { Weighted Mean Difference (Random) } \\
\qquad 95 \% \mathrm{Cl}\end{array}$} & \multirow{2}{*}{$\begin{array}{c}\text { Weight } \\
(\%)\end{array}$} & \multirow{2}{*}{$\begin{array}{l}\text { Weighted Mean Difference (Random) } \\
\qquad 95 \% \mathrm{Cl}\end{array}$} \\
\hline & $\mathrm{N}$ & Mean(SD) & N & Mean(SD) & & & \\
\hline Subtotal $(95 \% \mathrm{Cl})$ & 79 & & 78 & & $\bullet$ & 100.0 & $-0.17[-0.72,0.38]$ \\
\hline \multicolumn{8}{|c|}{ Test for heterogeneity chi-square $=2.99 \mathrm{df}=2 \mathrm{p}=0.22 \mathrm{I}^{2}=33.1 \%$} \\
\hline \multicolumn{8}{|c|}{ Test for overall effect $z=0.61 \quad p=0.5$} \\
\hline \multicolumn{8}{|c|}{04 insulin twice daily versus insulin nph morning plus sulphonylurea (SU) or SU+metformin } \\
\hline Lotz 1988 & 8 & $-1.72(1.60)$ & 8 & $-0.75(1.73)$ & $\rightarrow$ & 5.5 & $-0.97[-2.60,0.66]$ \\
\hline Wolffenbuttel 1991 & 22 & $-3.10(1.26)$ & 25 & $-2.42(1.31)$ & \# & 27.3 & $-0.68[-1.42,0.06]$ \\
\hline Wolffenbuttel 1996 & 34 & $-2.90(1.21)$ & 33 & $-2.52(1.17)$ & ت & 45.5 & $-0.38[-0.95,0.19]$ \\
\hline Yki-Järvinen 1992 & 29 & $-1.80(1.60)$ & 32 & $-1.70(1.70)$ & $\#$ & 21.6 & $-0.10[-0.93,0.73]$ \\
\hline Subtotal $(95 \% \mathrm{Cl})$ & 93 & & 98 & & $\bullet$ & 100.0 & $-0.43[-0.82,-0.05]$ \\
\hline \multicolumn{8}{|c|}{ Test for heterogeneity chi-square $=1.50 \mathrm{df}=3 \mathrm{p}=0.68 \mathrm{l}^{2}=0.0 \%$} \\
\hline \multicolumn{8}{|c|}{ Test for overall effect $z=2.21 \quad p=0.03$} \\
\hline & & & & & $\begin{array}{ll}-10.0 & -5.0\end{array}$ & & \\
\hline
\end{tabular}

\section{Analysis 02.02. Comparison 02 insulin twice daily versus insulin plus OHAs, Outcome 02 weight gain (change from baseline[kg]]}

Review: Insulin monotherapy versus combinations of insulin with oral hypoglycaemic agents in patients with type 2 diabetes mellitus Comparison: 02 insulin twice daily versus insulin plus OHAs

Outcome: 02 weight gain (change from baseline $[\mathrm{kg}]]$

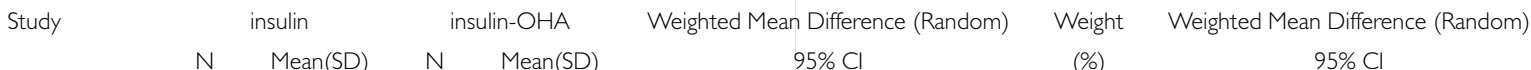

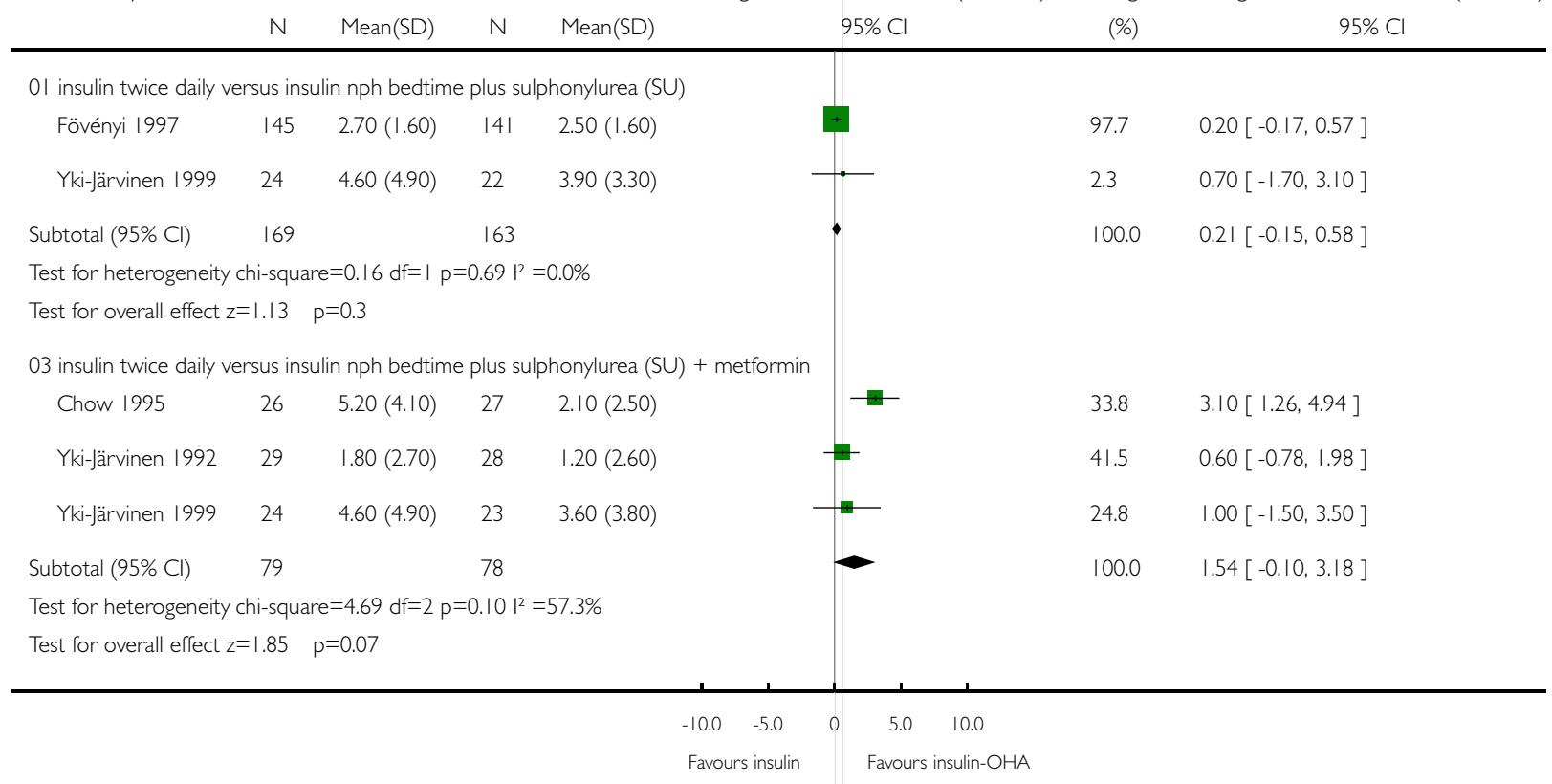

Insulin monotherapy versus combinations of insulin with oral hypoglycaemic agents in patients with type 2 diabetes mellitus (Review) 
Analysis 03.0I. Comparison 03 insulin basal/bolus versus insulin plus OHA, Outcome $0 \mathrm{I}$ HbA Ic (change from baseline [\%])

Review: Insulin monotherapy versus combinations of insulin with oral hypoglycaemic agents in patients with type 2 diabetes mellitus

Comparison: 03 insulin basal/bolus versus insulin plus $\mathrm{OHA}$

Outcome: $0 \mathrm{I} \mathrm{HbAlc} \mathrm{(change} \mathrm{from} \mathrm{baseline} \mathrm{[ \% ])}$

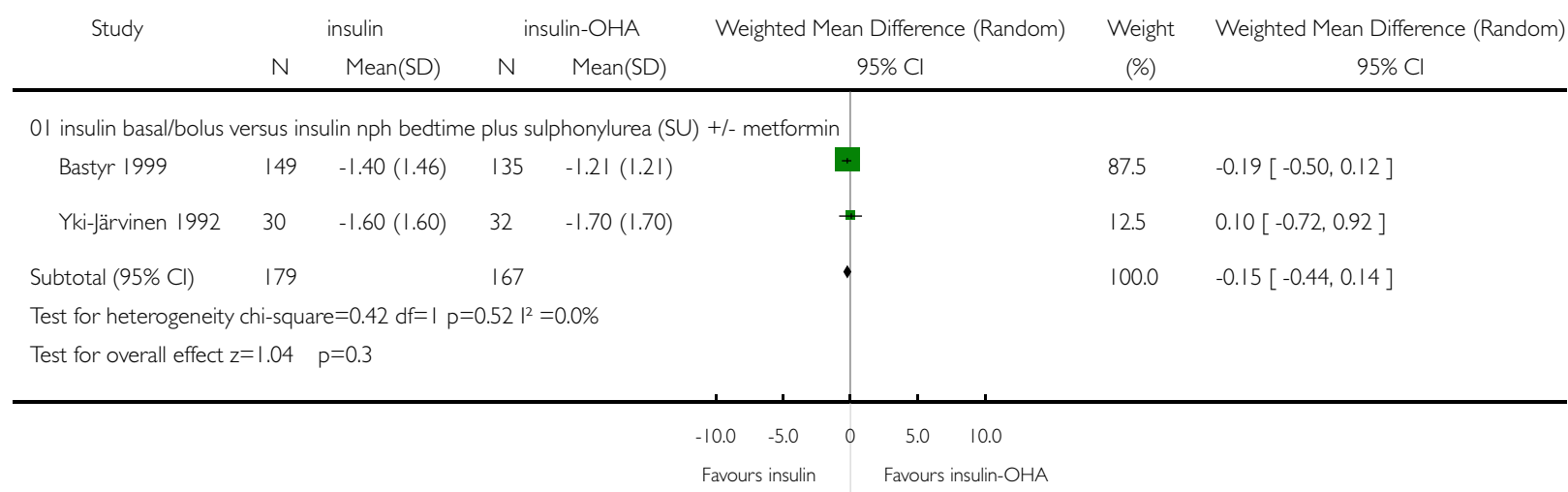

Analysis 03.02. Comparison 03 insulin basal/bolus versus insulin plus OHA, Outcome 02 weight gain (change from baseline[kg]]

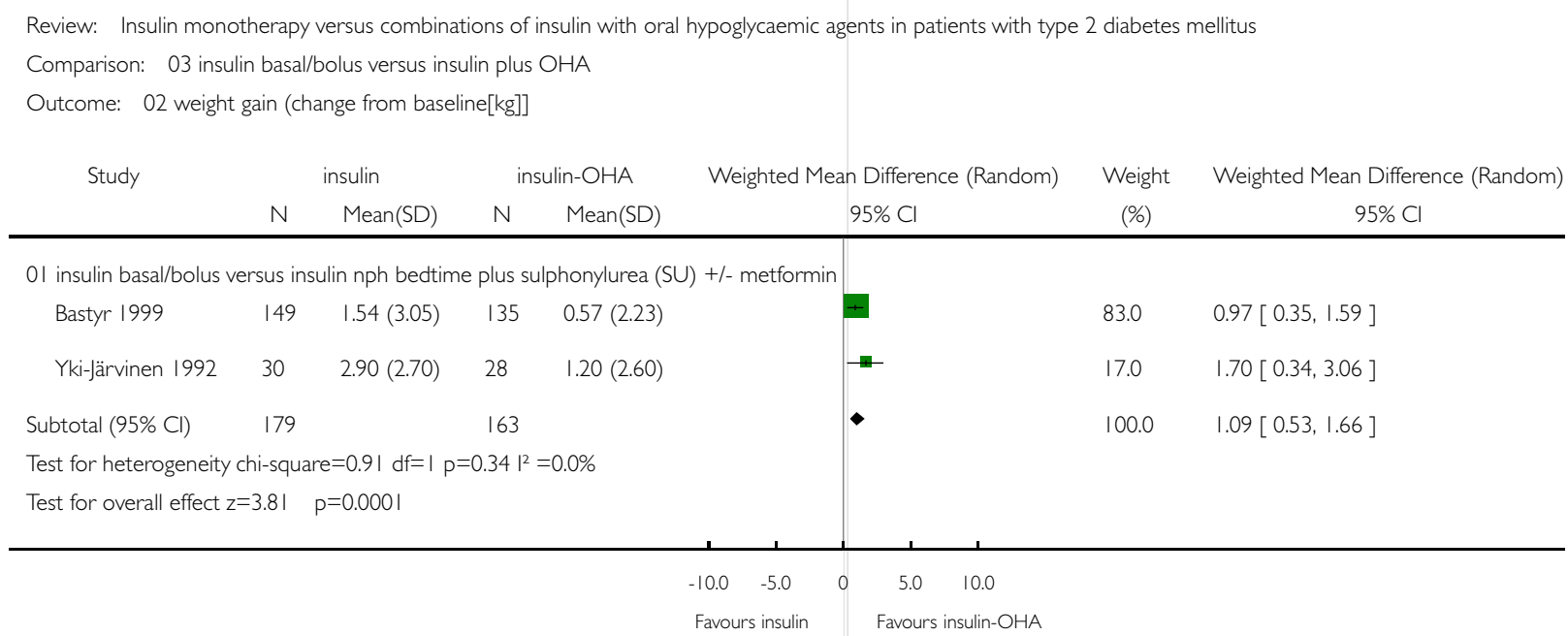


Analysis 04.01. Comparison 04 Insulin monotherapy versus insulin plus metformine $+/$ - sulphonylurea (SU), Outcome $0 \mathrm{I}$ HbA Ic (change from baseline [\%])

Review: Insulin monotherapy versus combinations of insulin with oral hypoglycaemic agents in patients with type 2 diabetes mellitus

Comparison: 04 Insulin monotherapy versus insulin plus metformine +/- sulphonylurea (SU)

Outcome: 0 I HbAlc (change from baseline [\%])

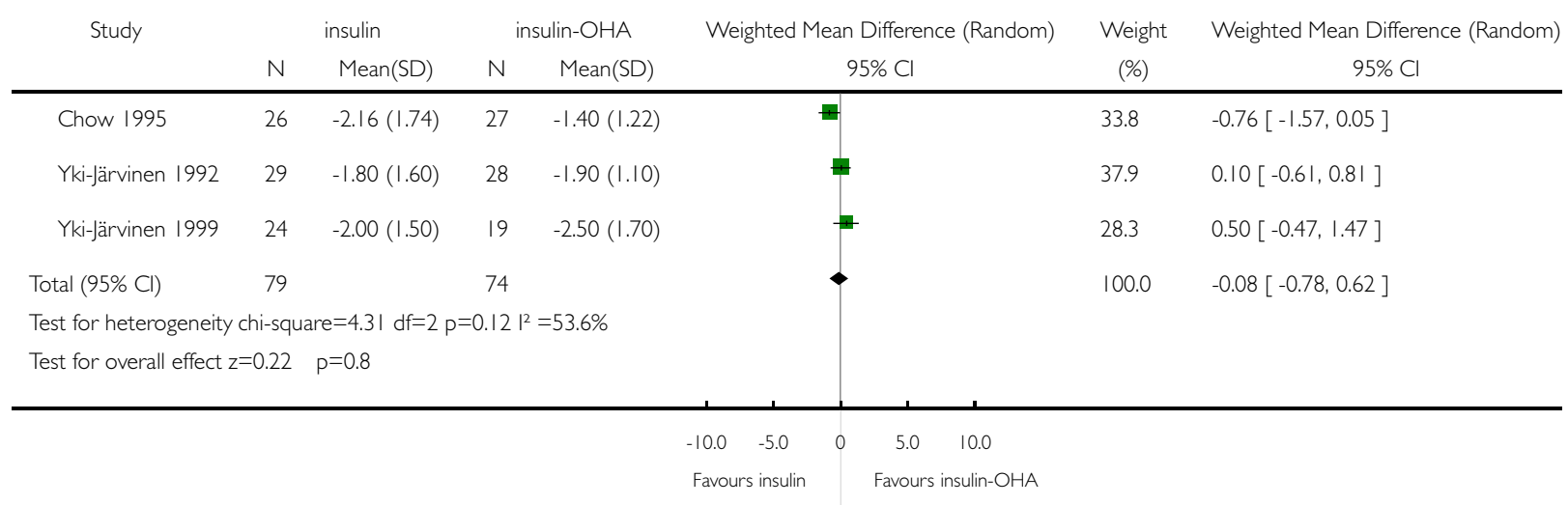

